\title{
GUIDE POUR L'INTERPRÉTATION DES ÉCAILLES ET L'ESTIMATION DE L'ÂGE CHEZ LES ALOSES (ALOSA SPP.) DE LA FAÇADE ATLANTIQUE-EST ET DE LA MÉDITERRANÉE-OUEST.
}

\author{
BAGLINIÈRE J.L. (1), SABATIÉ M.R. (1, 2) APRAHAMIAN M.W. (3), \\ ALEXANDRINO P.'(4), APRAHAMIAN C.D. (3), ASSIS C.A. ${ }^{1}$ (5), \\ CASSOU-LEINS J.J. (6), LE CORRE M. (1, 2), MENNESSON-BOISNEAU C. (7), \\ MARTIN-VANDEMBULCKE D. (8), ROCHARD E. (8), TEIXEIRA C. ${ }^{1}$ (9)
}

(1) UMR INRA-ENSA Ecobiologie et Qualité des Hydrosystèmes Continentaux, 65 rue de Saint-Brieuc, 35042 Rennes Cedex, France.

(2) Laboratoire Halieutique, ENSAR, 65 rue de St Brieuc 35042 Rennes Cedex, France.

(3) The Environment Agency P.O Box 12, Fairclough House, Knutsford Road, Warrington WA4 1HG, (U.K).

(4) Animal Genetics and Conservation Unit, Faculdade de Ciências, Universidade do Porto, Campus Agràrio de Vairão, R. Monte Crasto 4480 Vila do Conde, Portugal.

(5) Departamento de Zoologia e Antropologia e Instituto de Oceanografia, Faculdade de Ciências, Universidade do Lisboa, R. Ernesto Vasconcelos, Campo Grande, 1749-016 Lisboa, Portugal.

(6) Equipe Environnement Aquatique et Aquaculture, Laboratoire d'Ingénieurie Agronomique, ENSAT, avenue de l'Agrobiopole, BP. 107 Auzeville-Tolosane, F 31326 Castanet-Tolosan cedex, France.

(7) IBEAS, Faculté des Sciences, Université de Tours, 1 Parc Grandmont, 37200 Tours, France.

(8) Unité des Ressources Aquatiques Continentales, CEMAGREF, 50 avenue de Verdun, 33612 Cestas Cedex, France.

(9) Instituto de Oceanografia, Faculdade de Ciências, Universidade do Lisboa, R. Ernesto Vasconcelos, Campo Grande, 1749-016 Lisboa, Portugal.

\section{RÉSUMÉ}

L'objectif général de ce guide est de fournir un manuel d'utilisation et d'interprétation des écailles pour l'estimation de l'âge chez les aloses de l'Atlantique-Est et de Méditerranée-Ouest (Grande Alose, Alose feinte atlantique et méditerranéenne). Après un présentation rapide des espèces, populations et fleuves analysés, les écailles d'aloses et les méthodes de récolte, de préparation et de montage les concernant sont décrites en détail. Des définitions et un système de notation de l'âge standards sont donnés. La

\footnotetext{
1 Les deux équipes des Universités de Porto et de Lisbonne sont intégrées dans le projet n 3/3/C.A./1981/95 du programme PRAXIS XXI de la Fundação para a Ciência e Tecnologia.
} 
grande majorité des difficultés rencontrées pour l'interprétation des écailles sont analysées en proposant des solutions et en donnant certaines recommandations. L'ensemble de ce guide est largement illustré à l'aide d'exemples d'écailles typiques et atypiques choisis chez tous les taxons des différentes populations étudiées.

\section{INTRODUCTION}

Depuis la fin des années 1970, les aloses de l'Atlantique-Est et de la MéditerranéeOuest (Alosa alosa et $A$. fallax sp.) ont fait l'objet d'un certain nombre de programmes d'études, de restauration, de conservation et de protection. Cette attention est liée à la prise en considération de la forte fragmentation et réduction de leur aire de répartition et de l'ensemble des intérêts qu'elles présentent au même titre que les autres migrateurs amphihalins (Anguille, Esturgeon, Saumon atlantique, Truite de mer) et qui se placent au niveau (BAGLINIĖRE, 2000) :

- socio-économique : ces espèces constituent des ressources renouvelables exploitées par les pêcheries commerciales. Ainsi, en France, le tonnage annuel varie entre 500 et 1000 tonnes. A ce type d'exploitation s'ajoute la pêche sportive qui prend actuellement une certaine extension.

- scientifique : les aloses constituent un matériel intéressant pour l'étude de la biologie évolutive et de la conservation, notamment celles des phénomènes de spéciation et d'hybridation.

- écologique et patrimonial : la diversité des milieux fréquentés, la correspondance stock-fleuve, l'absence de comportement de saut et de populations d'élevage font de ces espèces des indicateurs privilégiés de la qualité biologique et de l'intégrité du fonctionnement longitudinal des cours moyens des grands bassins fluviaux.

Comme pour un certain nombre d'espèces, l'étude de la biologie et de l'écologie des aloses passe par l'analyse de leurs caractéristiques démographiques. Cette analyse nécessite l'estimation de l'âge qui se fait essentiellement à partir de structures dures à croissance périodique et notamment à partir des écailles. Mais, la scalimétrie chez les aloses reste d'une utilisation relativement difficile à la différence de celle pratiquée couramment chez les salmonidés migrateurs (BAGLINIĖRE, 1985 ; RICHARD et BAGLINIĖRE, 1990 ; ELLIOTT et CHAMBERS, 1996). De fait, le besoin d'une interprétation concertée et d'une homogénéisation des critères scalimétriques s'est fait plus ressentir que pour un grand nombre d'espèces.

Ainsi, un premier atelier sur l'estimation de l'âge par scalimétrie chez les aloses s'est tenu à Rennes du 1er au 3 décembre 1997. II a réuni la plupart des chercheurs engagés dans des études de l'estimation de l'âge de ces espèces dans leur aire de répartition en Atlantique-Est et en Méditerranée-Ouest. Son principal objectif était d'homogénéiser les critères scalimétriques pour l'interprétation de l'âge, tout en fournissant un guide d'interprétation des écailles d'aloses. Au cours de cet atelier, les écailles des trois taxons du genre Alosa actuellement reconnus en Atlantique-Est et en Méditerranée-Ouest (Alosa alosa, $A$. fallax fallax et $A$. fallax rhodanensis) (voire leurs hybrides) et provenant des populations de différents pays (Royaume-Uni, France, Portugal, Maroc) ont été examinées et comparées.

Cet article fait la synthèse de l'ensemble des problèmes et des difficultés rencontrés pour l'estimation de l'âge chez les aloses et propose à la fois un certain nombre de définitions, de solutions et de recommandations tout en présentant en illustration un maximum de cas typiques et atypiques. 


\section{PRÉSENTATION DES COURS D'EAU ET DES POPULATIONS D'ALOSES ANALYSÉES}

Les populations d'aloses analysées proviennent de dix cours d'eau répartis sur leur aire de répartition actuelle en Atlantique-Est et en Méditerranée-Ouest depuis le Nord de l'Angleterre $\left(52^{\circ}\right.$ lat. $\left.\mathrm{N}\right)$ jusqu'au Maroc $\left(34^{\circ}\right.$ lat. $\left.\mathrm{N}\right)$ à savoir : la Severn, la Loire, la Dordogne, la Garonne (voire la Gironde, estuaire commun de ces deux fleuves), le Rhône, le Lima, le Tage, le Zézère (affluent du Tage), le Guadiana et l'oued Sebou (Tableau I).

L'alose feinte ( $A$. fallax fallax) sous sa forme migratrice amphihaline est présente sur tous les cours d'eau de la façade atlantique. Cette espèce est également présente sur le bassin méditerranéen sous la forme d'un taxon identifié morphologiquement par QUIGNARD et KARTAS (1977) comme une sous-espèce de l'alose feinte ( $A$. fallax rhodanensis). En fait, cette forme de l'Alose feinte méditerranéenne reste particulière pour deux raisons : ses caractéristiques méristiques et génétiques la rattachent à l'espèce $A$. fallax sans qu'actuellement son rang de sous espèce ait pu être confirmé génétiquement (LE CORRE et al., 1998) ; sa grande taille au stade adulte et sa capacité de migration à longue distance en eau douce la rapprochent fortement de la grande Alose (LE CORRE et al., 2000).

La grande Alose ( $A$. alosa) sous sa forme migratrice n'est plus présente sur la Severn, a disparu très récemment (1992) de l'oued Sebou mais semble encore présente sur le Tage (population peu abondante). Cependant, dans un affluent de ce dernier fleuve (rivière Zézère), elle est trouvée sous une forme lacustre (non amphihaline) suite à la création d'un barrage (Castelo de Bode) à son embouchure avec le Tage, il y a une quarantaine d'années (ALEXANDRINO, 1996). Enfin, la grande alose, considérée comme rare sur la façade méditerranéenne française (ROULE, 1924) mais introduite dans le Rhône à partir de la Dordogne dans le milieu de ce siècle (HOESTLANDT, 1958) paraît avoir totalement disparu de ce fleuve aujourd'hui (LE CORRE et al., 1997).

Des éléments très généraux sur la biologie de ces diverses populations sont donnés dans le tableau I.

Chez la grande Alose, en dépit d'une grande variabilité inter-annuelle au sein de chaque population, il existe un gradient croissant de taille et de poids du nord au sud de son aire de répartition. Ainsi, la croissance en longueur et en poids des aloses méridionales (Lima et oued Sebou) est plus forte (SABATIÉ, 1993 ; SABATIÉ et al., 1996) que celle des autres populations, ce qui est en accord avec les observations faites par EIRAS (1981) et par ALEXANDRINO (1996) sur deux autres stocks portugais (Douro, Mondego). Les performances des aloses colonisant les cours d'eau plus nordiques apparaissent relativement homogènes. Cependant, les poissons de la Loire semblent montrer une croissance plus forte que ceux du système Gironde-Garonne-Dordogne et de l'Adour (MENNESSON-BOISNEAU et al., 2000).

Chez l'Alose feinte, les caractéristiques métriques et pondérales des différentes populations atlantiques paraissent dans l'ensemble assez semblables. Néanmoins, il existe quelques différences notables. Ainsi, les populations du Tage se distinguent par leur petite taille tandis que celles du Lima présentent les plus forts gabarits jamais enregistrés pour l'espèce dans son aire de répartition atlantique (ALEXANDRINO, 1996). Par ailleurs, les populations à plus fort taux de croissance semblent être celles de la Loire (MENNESSON-BOISNEAU et BOISNEAU, 1990). Enfin, le taux de croissance des populations marocaines apparaît relativement élevé lors de la première année puis devient semblable, par la suite, à celui des autres stocks (SABATIÉ, 1993). En revanche, comparées aux stocks atlantiques, les populations méditerranéennes (Rhône, Aude et Hérault) présentent des gammes de taille, de poids et un taux de croissance supérieurs (DOUCHEMENT, 1981 ; LE CORRE et al., 2000). 


\section{DESCRIPTION DES ÉCAILLES D'ALOSES}

Les écailles d'aloses européennes ont été décrites par un certain nombre d'auteurs (HASS, 1965; BERG, 1966 ; CASSOU-LEINS et CASSOU-LEINS, 1981; DOUCHEMENT, 1981; APRAHAMIAN, 1982 ; BAGLINIĖRE et LE LOUARN, 1987 ; MENNESSON-BOISNEAU et BOISNEAU, 1990). Elles sont de type cycloïde et tout à fait typiques de celle des Clupéidés. Leur forme est polygonale en présentant un léger dôme dans leur champ antérieur (Figure 1). Cette forme peut se modifier par suite d'une érosion lors du retour en rivière des adultes en liaison avec la maturation sexuelle : de polygonale, l'écaille devient plus ovale, le dôme du champ antérieur disparaissant. Le focus ou centre est excentré vers le champ postérieur qui est de fait réduit (30 à $40 \%$ de la dimension de l'écaille).

Quatre grands types d'ornementations sont observés (Figure 1) :

* la ligne basale qui est le premier circulus marquant la limite entre les champs antérieur et postérieur de l'écaille ; elle peut traverser le focus.

* des sillons transverses, fortement marqués, présents dans tout le champ antérieur de l'écaille; ce sont des lignes foncées, initialement parallèles à la ligne basale qui peuvent se réunir au centre de l'écaille ; ils recoupent les deux autres types d'ornementations en passant d'un champ latéral à l'autre.

* une striation très fine et serrée correspondant aux circuli. Ces circuli sont déposés de manière relativement transverse mais plus concentrique vers le bord de l'écaille. Cette striation est absente du champ postérieur.

* des anneaux concentriques présents dans tous les champs de l'écaille (ils apparaissent, même, sur le champ postérieur lorsque l'angle de la lumière est modifié) ; lls définissent les limites d'arrêt de croissance ou anneaux d'âge.

\section{EXAMEN SCALIMÉTRIQUE}

\section{Prélèvement, préparation et montage des écailles}

Une zone standard de prélèvement des écailles a été définie chez les poissons adultes (Figure 2). Cette zone possède des écailles de forme typique, à faible pourcentage de régénération et généralement plus lisibles (anneaux d'âge plus nets, moindre recoupement des marques de reproduction). D'une manière générale, cette zone se situe au milieu du corps de part et d'autre de la ligne longitudinale (pas de ligne latérale visible chez ces espèces). Cependant, la localisation précise de cette zone standard diffère légèrement selon l'espèce.

Ainsi, chez la grande Alose, la zone optimale de prélèvement se situe au-dessus de la ligne longitudinale et sur une ligne joignant l'attache postérieure de la nageoire dorsale à celle antérieure de la nageoire anale (MENNESSON-BOINEAU et BOISNEAU, 1990). En revanche, chez l'Alose feinte, elle se situe plus en avant du corps soit à l'aplomb de la pointe supérieure de la nageoire dorsale et à 1 à 2 rangs en dessous de la ligne longitudinale (APRAHAMIAN, observation non publiée ; ASSIS, observation non publiée).

Par ailleurs, aucune étude relative à la définition d'une zone standard de prélèvement d'écailles n'a été réalisée chez les individus hybrides et les adultes d'Alose feinte méditerranéenne. Jusqu'à présent, les écailles de ces deux groupes ont toujours été prélevées sur la zone standard définie chez la grande Alose. Cependant, il semblerait 
souhaitable à l'avenir pour l'espèce méditerranéenne d'utiliser la zone définie chez l'Alose feinte atlantique dans la mesure où elle permet de mieux individualiser les marques de reproduction qui peuvent être nombreuses. Quant aux hybrides, l'utilisation de l'une ou l'autre des deux zones définies reste fonction de la lisibilité de leurs écailles. Enfin, il faut signaler que la validation de ces zones pour les juvéniles et les immatures reste à faire même si elles peuvent être utilisées comme telles pour l'instant. Encore faut-il préciser qu'il reste souvent difficile de récolter des écailles sur les alosons compte tenu de leur grande fragilité (très grosse perte d'écailles lors de la capture).

Il est recommandé de prélever entre 6 à 20 écailles par poisson et si possible de le faire par petit site sur l'ensemble de la zone standard. Le nombre minimum de 6 est particulièrement recommandé pour les poissons âgés et doit correspondre à des écailles sans aucune régénération (tri effectué à la loupe binoculaire).

Les écailles doivent être impérativement nettoyées. Leur nettoyage, quant elles viennent d'être prélevées, peut se faire à sec entre deux doigts. Plus couramment, les écailles sèches sont placées dans un bain de produits décapants à très faible dose $(\mathrm{KOH}$ à $5 \%$, Trypsine) durant un temps limité (<trois minutes), puis rincées et nettoyées à l'aide d'un pinceau raide. Le nettoyage peut également être effectué par une méthode ultrasonique ce qui semblerait apporter à la fois un gain de temps et une plus grande propreté de l'écaille mais ceci reste encore à démontrer. Après nettoyage, les écailles peuvent être soit lues directement sans montage soit placées entre lame et lamelle ou entre deux lames à raison d'au moins 6 par poisson. L'impression sur film plastique est déconseillée car elle fait mal apparaître les structures de l'écaille.

En général, les écailles sont lues et interprétées à l'aide de matériels optiques grossissants (x10 ou 50) tels que les loupes binoculaires, les lecteurs de microfiches ou de profil. Cependant, une technique microradiographique (rayons $X$ ) a été utilisée avec succès chez la grande Alose par CASSOU-LEINS et CASSOU-LEINS (1981) qui la considèrent comme nettement plus performante pour l'identification des annuli que la méthode optique (Figure 3). Cette technique microradiographique a été reprise récemment avec l'aide du Laboratoire d'Ichtyologie Générale et appliquée du Muséum National d'Histoire Naturelle de Paris (collaboration F.J. MEUNIER) pour analyser les écailles de l'Alose du Rhône. Cependant, elle n'a pas permis, d'améliorer l'interprétation des écailles par rapport à la méthode classique de lecture, les causes en restant inconnues.

\section{Définitions préliminaires}

\section{Annulus ou anneau hivernal}

En scalimétrie, l'annulus correspond à une discontinuité structurale faisant le tour de l'écaille et se traduisant le plus souvent par un resserrement, un recoupement ou par une fusion des circuli (BAGLINIĖRE et al., 1992). Si cette définition générale se retrouve chez l'Alose (CASSOU-LEINS et CASSOU-LEINS, 1981 ; DOUCHEMENT, 1981), il faut néanmoins l'élargir en raison de la très grande variabilité de morphologie et d'intensité observée chez l'annulus de ces espèces (MENNESSON-BOISNEAU et BAGLINIÈRE, 1992). Ainsi, un annulus peut-être décrit comme une ligne blanche (claire) parallèle au bord de l'écaille (Figure 4a), marquant une déstructuration ou une distorsion des circuli. Ces derniers sont alors coupés ou déformés et leurs reprises ne coïncident pas exactement. Cette ligne est, en général, visible sur tout le pourtour de l'écaille (essentiellement les champs latéraux et antérieur) (Figures 4b et 4c). Certains annuli, peu marqués, ne sont repérables que par un contraste entre la bande plus foncée de stries hivernales et celle plus claire qui marque la reprise de croissance avec des intervalles de dépôts plus larges. A ce niveau, ils sont aussi décelés par une distorsion et/ou une différence d'épaississement bien visible à fort grossissement ou une ramification des stries fines sans coupure des stries transversales (Figure 5). En revanche, d'autres, très 
marqués possèdent de larges bandes blanches cicatrisées avec ou sans désorganisation des stries fines (Figure 6).

\section{Marque de reproduction}

La marque de fraie ou de reproduction apparaît comme une ligne continue concentrique plus ou moins claire, faisant le tour de l'écaille, de largeur très variable, recoupant les stries fines et présentant une déstructuration plus nette que celle de l'anneau hivernal (Figure 7). Au-delà de cette ligne, deux types de disposition de stries fines correspondant à un niveau de désorganisation de la structure de l'écaille peuvent être observés : (1) stries parallèles à la marque de reproduction qui est souvent bordée d'un circulus épais, correspondant à une moindre désorganisation (Figure 8) ; (2) stries agrégées en îlots, entrecoupées de larges taches blanches, correspondant à une forte désorganisation structurelle (Figure 9). En règle générale, cette marque de reproduction n'est pas souvent observée sur les écailles de la grande Alose en raison du caractère semelpare de l'espèce (au maximum 5 à $6 \%$ de géniteurs des stocks atlantiques se reproduisent une seconde fois) à l'exception des populations lacustres (enfermées) qui peuvent se reproduire plusieurs fois. En revanche, chez l'Alose feinte, plus de $30 \%$ des adultes des populations atlantiques et méditerranéennes présentent une marque de fraie sur leurs écailles, traduisant le caractère itéropare de l'espèce (MENNESSON-BOISNEAU et al., 2000). De plus, lorsque cette marque apparaît, elle est, en général, de moins en moins accentuée lorsque l'on passe de la grande Alose, à l'Alose feinte et à la forme lacustre (voir Figures 7, 8 et 9).

\section{Date anniversaire}

Chez l'Alose anadrome, il a été considéré que la date anniversaire devait correspondre à la date médiane de la période de reproduction. Cependant, cette date varie largement selon l'espèce et la position latitudinale du cours d'eau. Ainsi, elle s'échelonne sur deux mois depuis le 1er mai pour les aloses du Maroc (SABATIÉ et al., 1996) jusqu'au 1er juillet pour la grande Alose en France (CASSOU-LEINS et CASSOU-LEINS, 1981 ; DAUTREY et LARTIGUE, 1983 ; MENNESSON-BOISNEAU et al., 1986 ; TAVERNY, 1991) et l'Alose feinte de la Loire (MENNESSON-BOISNEAU et BOISNEAU, 1990) en passant par le 15 mai pour la grande Alose du Lima (SABATIÉ et al., 1996) et le 1er juin pour l'Alose feinte du Rhône (LE CORRE et al, 1997) et celle de la Severn (APRAHAMIAN, 1982). Ainsi, aucune date anniversaire universelle ne peut être retenue pour l'estimation de l'âge chez les populations migratrices. Cela signifie que dans tout travail concernant l'estimation de l'âge, les auteurs se doivent de préciser la date anniversaire retenue pour la population étudiée, si elle est connue. En revanche si elle ne l'est pas, il pourra être possible d'utiliser celle d'une population de la même espèce proche géographiquement.

En revanche, chez les aloses lacustres (enfermées) des deux espèces, il semble que l'on puisse retenir une date anniversaire théorique correspondant à l'époque de formation de la marque hivernale.

\section{Date de formation de l'annulus}

La date de formation de l'annulus a été surtout étudiée chez les alosons des deux espèces. L'apparition du premier anneau hivernal sur les écailles varie avec la position latitudinale de la population. Ainsi, elle peut apparaître au milieu ou à la fin de l'hiver pour les stocks les plus méridionaux (SABATIÉ, 1993 ; ASSIS, observation non publiée). En revanche, elle semble apparaître plus tard pour les populations lacustres et plus septentrionales et serait visible sur tous les alosons entre mai et juin (BERG, 1966 ; APRAHAMIAN, 1982 ; TAVERNY, 1991). 
Cela signifie qu'une date théorique ne peut être retenue et que le premier anneau d'âge se forme chez l'aloson en moyenne 9,5 et 10,5 mois après l'éclosion respectivement chez la grande Alose et l'Alose feinte. Ainsi, il apparaît nécessaire de connaître d'une manière plus précise la date médiane de formation de l'annulus par bassin versant, population ou espèce en suivant si possible l'accroissement marginal des écailles dans le temps.

\section{Notation de l'âge}

L'âge est noté en comptabilisant le nombre total d'annuli présents sur l'écaille sans distinguer les phases eau douce et marine. En effet, à la différence des salmonidés migrateurs (BAGLINIĖRE, 1985), il n'est pas possible de séparer la phase eau douce de celle marine car le premier anneau hivernal apparaît généralement après le passage en mer (TAVERNY et al., 2000). Par ailleurs, pour les poissons remontant en eau douce lors de la migration de reproduction, il a été convenu de considérer le bord de l'écaille comme un anneau d'âge même si le dernier annulus n'y est pas visible mais à condition que la plage de l'écaille comprise entre le dernier annulus visible et son bord puisse correspondre à un phase de croissance annuelle (ne pas tenir compte de la partie translucide du bord de l'écaille). Ainsi, l'âge total du poisson est la somme du nombre d'annuli observés plus un correspondant au bord de l'écaille. II a également été convenu que la notation de l'âge devrait comporter, si possible, un exposant correspondant au nombre de reproductions antérieures. Ainsi, si un poisson est noté 4 , cela signifie qu'il est âgé de 4 ans sans aucune autre indication; s'il est noté $4^{\circ}$, cela signifie qu'il est âgé de 4 ans et vierge et enfin si ce poisson est noté $4^{n}$, cela veut dire qu'il est âgé de 4 ans et qu'il s'est déjà reproduit $n$ fois avant la capture. Par ailleurs, la date et le lieu de capture, l'état de maturation de gonades et le degré d'érosion des écailles d'un poisson lors de sa capture apparaissent comme autant d'informations permettant d'estimer le nombre potentiel de reproductions d'une population. Un moyen simple pour estimer le degré d'érosion des écailles pourrait consister à analyser l'indice de forme de l'écaille (plus grand diamètre longitudinal/plus grand diamètre transversal (BURDAK, 1986)) au cours de la migration de reproduction. Enfin, dans le cas où le poisson est capturé bien après la date anniversaire et qu'il présente sur son écaille une nette reprise de croissance, il n'est pas possible de considérer qu'il soit âgé d'un an en plus. Dans ces conditions, il a été recommandé d'affecter l'âge du signe + (Figure 10).

\section{Pourcentage d'attribution de l'âge}

Un pourcentage d'attribution de l'âge à partir de la lecture des écailles d'adultes (déjà préparées avant leur lecture donc normalement non régénérées) est donné pour un certain nombre de populations analysées au cours de cet atelier. Ce pourcentage reste élevé mais varie suivant l'espèce et la population (Tableau II). II diminue avec l'âge et donc chez les femelles dans la mesure où celles-ci sont en moyenne plus âgées que les mâles. L'absence d'attribution d'un âge est due à la présence d'écailles illisibles (trop de marques, marques indéfinies, érosion de surface) et/ou présentant un bord antérieur fortement érodé.

\section{Quelques exemples d'écailles typiques}

Des écailles ne présentant à priori pas ou peu de difficultés de lecture sont présentées en essayant de couvrir une large gamme de tailles et d'âges des individus vierges ou s'étant déjà reproduits, issus des différentes populations analysées chez les deux espèces y compris les formes lacustres (Figures 11 à 45). Tous les poissons dont les écailles sont présentées ont été capturés avant la date anniversaire. La longueur à la fourche (LF), exprimée en millimètres, est reliée à la longueur totale (LT) par la relation : $\mathrm{LF}=\mathrm{LT}-60$ (MENNESSON-BOISNEAU et al., 1986). 


\section{Difficultés rencontrées, propositions de solutions et recommandations}

\section{Généralités}

Les difficultés rencontrées lors de la lecture d'écailles d'aloses varient en fonction de l'espèce, de la population et de l'âge (et donc du sexe voir paragraphe attribution de l'âge) ainsi que d'une écaille à une autre pour un même individu (d'où la nécessité de monter au moins six écailles par poisson).

Ainsi, il semble que les écailles d'aloses feintes et d'individus les plus jeunes soient plus souvent facilement interprétables que celles des grandes aloses et des individus plus âgés (MENNESSON-BOISNEAU et BOISNEAU, 1990). II en est de même pour les écailles des mâles par rapport à celles des femelles (APRAHAMIAN, observation non publiée). Cette différence entre les deux espèces est due moins à la plus faible longévité des aloses feintes qu'à leur plus faible taux de croissance puisque les écailles considérées comme les plus facilement lisibles durant cet atelier (indépendamment du fait qu'elles avaient été triées lors de leur présentation) provenaient de la population de la Severn dont l'âge maximum peut atteindre 13 ans et donc largement dépasser celui généralement observé pour la grande Alose ( 8 ans) en France ou au Maroc. Cependant, cette règle générale de différence de lisibilité entre les écailles des deux espèces d'aloses semble comporter au moins deux exceptions. La première concerne les populations d'aloses marocaines pour lesquelles la lecture des écailles apparaît plus facile chez la grande Alose (SABATIÉ, 1993). La deuxième concerne les populations d'aloses feintes du Rhône chez lesquelles il a été constaté que les écailles étaient les plus difficilement interprétables de toutes celles analysées. Le facteur qui peut être évoqué est à nouveau le taux de croissance le plus élevé jamais observé chez les aloses feintes.

\section{Type de difficultés et solutions d'aide à une estimation correcte de l'âge}

Les principales difficultés rencontrées lors de cet atelier sont présentées et pour chacune d'entre elles est proposée une solution technique. Ce sont :

- La présence de marques supplémentaires.

Elles peuvent être assez proches de la marque hivernale et constituer une structure de double anneau plus ou moins large (Figures 11, 46 et 47). Cette " structure » de double anneau peut être identifiée dès le premier hiver. Cet anneau appelé alors « surnuméraire " a été observé sur les écailles des deux espèces d'aloses de toutes les populations françaises (DOUCHEMENT, 1981; MENNESSON-BOISNEAU et BOISNEAU, 1990) (Figures 14 et 48). Néanmoins, il n'est pas visible sur les écailles de tous les individus d'une même cohorte ou d'une même population et sa fréquence d'apparition semblerait plus élevée chez l'Alose feinte que chez la grande Alose (DOUCHEMENT, 1981). Par ailleurs, cette "structure » de double anneau peut être présente sur toute l'écaille notamment dans le cas des aloses feintes marocaines (SABATIÉ, 1993).

Quant aux marques supplémentaires isolées, elles peuvent se localiser partout sur l'écaille (Figures 27 et 28) et même avant le premier hiver (cas des populations du Tage et de l'oued Sebou). Sur les écailles de certains individus de l'oued Sebou, cette marque dite de « crue » peut être très proche du centre de l'écaille (SABATIÉ, ibidem) (Figure 49).

En règle générale, les marques supplémentaires se distinguent des anneaux d'âge par plusieurs caractéristiques : elles ne font que rarement le tour complet de l'écaille, leur structure est moins marquée (inflexion et épaisseur plus large) et elles ne prennent pas naissance sur la ligne basale (sauf dans certains cas pour celles présentes avant le premier hiver). Cependant, dans certains cas, la distinction entre une ligne d'arrêt de 
croissance et un anneau supplémentaire peut rester difficile et le recours à l'otolithe n'apporte pas toujours la solution (MENNESSON-BOISNEAU et BOISNEAU, 1990).

- L'observation d'anneaux hivernaux soit totalement absents soit imperceptibles (Figure 50). Cette difficulté semble se rencontrer assez souvent sur les écailles des aloses feintes méditerranéennes. Dans ces populations, les annuli qui suivent le premier hiver sont souvent difficiles à observer. Il est cependant assez rare d'observer ce phénomène sur toutes les écailles montées. Par ailleurs, un examen à un fort grossissement permet souvent de déceler les anneaux hivernaux. De plus, l'examen des otolithes pourrait être un moyen permettant de pallier cette impossibilité d'interpréter l'écaille.

Dans ce cadre, il faut également signaler le problème fréquemment rencontré, posé par l'absence d'annulus au bord de l'écaille même si celui ci semble, toutes proportions gardées, encore intact. II a alors été convenu de considérer le bord de l'écaille comme le dernier annulus (voir notation de l'âge). Cependant, cette recommandation demande à être vérifiée.

- L'existence de marques hivernales « cicatrices » liée à des accidents d'érosion qui peut entraîner une possible confusion avec les marques de reproduction. Ce phénomène apparaît assez caractéristique des écailles des populations marocaines et essentiellement chez la grande Alose (Figures 6 et 19 (voir $5^{\text {ième }}$ hiver)). Néanmoins, un examen plus précis de la structure de ces marques permet généralement de les différencier des anneaux de ponte eu égard à leur description évoquée plus haut.

- La localisation difficile sur l'écaille du premier anneau hivernal (Figure 51). Prenant en compte à la fois la littérature (DOUCHEMENT, 1981) et les résultats d'analyses faites sur les poissons observés durant l'atelier, il a été décidé que toute marque se situant entre le premier et le troisième sillon transverse devait être considérée comme la première bande hivernale quelle que soit l'espèce (Figure 52). De même, la seconde bande hivernale se situerait entre les cinquième et septième sillons transverses. Mais la localisation des deux premiers annuli en fonction du nombre de sillons transverses peut varier selon le stock. Néanmoins, l'identification du deuxième arrêt de croissance semble poser généralement moins de problème car cet anneau hivernal apparaît comme souvent bien marqué sur l'écaille à l'exception néanmoins des populations d'Alose feinte du Rhône et du Tage (pas de localisation sur $22,4 \%$ des écailles pour ce dernier fleuve).

- La gêne occasionnée par un important phénomène d'érosion très fréquent en bordure et qui peut l'être également sur la surface de l'écaille (Figure 53). Ce phénomène d'érosion est d'autant plus important que la capture du poisson est faite à une période proche de la reproduction et que l'individu est âgé. Un tel phénomène est responsable de la suppression de marques hivernales et/ou de la fusion totale ou partielle de deux marques de reproduction (en bordure de l'écaille ou non), cette dernière conséquence affectant spécialement l'Alose feinte (plusieurs reproductions) (Figure 54). II peut conduire, alors, à une sous-estimation de l'âge jusqu'à 2 ans comme cela a été montré chez la grande Alose (MENNESSON-BOISNEAU et BOISNEAU, 1990). Dans ces conditions, il apparaît nécessaire d'avoir recours à l'examen de l'otolithe dans la mesure où celui-ci ne présente aucun phénomène d'érosion.

- La présence d'un anneau hivernal après ou juste avant une marque de reproduction. De telles observations sont rares dans les populations anadromes mais ont été faites sur celle d'Alose feinte du Tage. Signalons qu'elles ont également été réalisées chez certaines populations d'Alose savoureuse, A. sapidissima (KING, comm. pers.).

Dans le premier cas, une telle situation ne peut être envisagée que si les aloses peuvent présenter un repos de reproduction. Ceci n'a jamais été signalé jusqu'à présent et 
nécessiterait, donc, l'acquisition de données supplémentaires. En leur absence, il est considéré que seule la marque de reproduction est retenue pour l'estimation de l'âge.

Dans le second cas constaté également chez les populations d'aloses feintes du Rhône, cette situation semble correspondre à une érosion incomplète de l'anneau hivernal empêchant alors la fusion des deux marques qu'il semble logique de considérer alors comme un seul anneau d'âge. A la différence des populations anadromes, l'apparition de ces marques consécutives semble relativement plus commune pour les populations lacustres ( $A$. fallax lacustris: BERG, 1966). Néanmoins, dans les cas du stock enfermé du Castelo do Bode, ce phénomène n'a jamais été observé.

\section{Recommandations générales}

En plus des différentes solutions techniques proposées pour résoudre les difficultés rencontrées et ainsi estimer correctement l'âge du poisson, un certain nombre de recommandations générales s'imposent. Ce sont :

- Une bonne connaissance de la biologie soit du stock analysé (juvénile à l'adulte) soit plus généralement de l'espèce étudiée dans son aire de répartition biogéographique. En particulier, la longévité, le taux de croissance, la structure de taille des géniteurs (individus maturants), la taille à première maturité sexuelle, le sexe, et les périodes de migration et de reproduction (date anniversaire) restent des éléments biologiques indispensables à prendre en compte pour éviter des erreurs grossières. A titre d'exemple dans le cas de la présence d'une multitude de structures de type double anneau, la comptabilisation de toutes les marques identifiées ne doit pas aboutir à une estimation de l'âge incompatible avec les données connues d'espérance de vie.

- Une bonne utilisation des définitions évoquées plus haut concernant la structure d'une marque hivernale et de reproduction. Dans ces conditions, il paraît indispensable d'analyser l'écaille à un très fort grossissement (x50 voire x100).

- L'emploi d'autres structures dures et notamment les otolithes. Leur utilisation apparaît comme un bon outil complémentaire pour beaucoup de populations d'aloses (Loire : MENNESSON-BOISNEAU et BOISNEAU, 1990 ; Garonne et Dordogne : TAVERNY (1991)). Cependant, des expériences de validation sont encore nécessaires pour bien identifier la première LAC sur cette structure dure. En revanche, la lecture des otolithes n'apparaît pas plus appropriée que celle des écailles pour certaines populations (aloses méditerranéennes (LE CORRE, données non publiées) et marocaines (SABATIÉ, 1993)) en raison de leur faible lisibilité due probablement à un fort taux de croissance.

- La mise en place d'une clé taille-âge à partir d'un échantillon d'individus n'ayant pas, à priori, posés de problème d'estimation d'âge à partir de leurs écailles voire de leurs otolithes.

- La nécessité de valider la technique scalimétrique (BEAMISH et MCFARLANE, 1983) selon les méthodes proposées notamment par OMBREDANE et BAGLINIĖRE (1992) : la variation dans l'abondance relative des cohortes au cours du temps permettant la reconnaissance et le suivi d'une d'entre elles, l'agrément entre le nombre d'annuli sur les écailles et celui des modes des diagrammes de fréquence de taille, la comparaison avec des poissons d'âge connu (capture-recapture, suivi en captivité (méthodes pas encore mises en œuvre chez les Aloses de l'Atlantique-Est et de la Méditerranée-Ouest), et le rétrocalcul des tailles (ou des poids) aux âges antérieurs à la capture.

L'utilisation de cette dernière méthode ne semble pas faire l'unanimité dans la mesure où, d'une part, la position des anneaux hivernaux est quelquefois difficile à identifier chez certaines populations et que, d'autre part, les écailles des géniteurs 
(notamment les individus âgés) s'érodent au cours de la remontée. Des comparaisons entre les longueurs rétrocalculées à partir des écailles et celles directement observées ont été faites par DOUCHEMENT (1981), APRAHAMIAN (1982) et SABATIÉ (1993). Dans la seconde étude, il n'apparaît pas de différences statistiques entre les longueurs à un âge donné pour les individus d'une même cohorte. A l'inverse, les deux autres études montrent que les longueurs réelles restent supérieures à celles rétrocalculées chez des individus de cohortes différentes. Compte tenu de ces observations, il ressort que la méthode de rétrocalcul peut biaiser les résultats et que son utilisation comme technique de validation nécessite de s'entourer d'un certain nombre de précautions qui se placent à deux niveaux.

- Le premier est d'ordre général et demande de démontrer trois conditions (FRANCIS, 1990) : (1) la mesure du rayon d'une marque hivernale identifiée sur l'écaille doit être la même que celle de l'écaille à l'époque où la marque s'est formée ; (2) l'époque de formation de la marque est supposée être correcte ; (3) la formule utilisée reliant la longueur du poisson à celle de l'écaille est valable pour chaque individu.

- Le deuxième niveau de précautions concerne spécifiquement les aloses, à savoir (1) mesurer le rayon total de l'écaille depuis son centre à son apex où l'érosion reste la plus faible (APRAHAMIAN, 1982) ; (2) utiliser les individus d'une même cohorte compte tenu de l'importance de la variabilité annuelle de croissance ; (3) privilégier la rétromesure chez les immatures et les géniteurs avant leur première reproduction.

\section{REMERCIEMENTS}

Nous tenons à remercier Monsieur Thomas LEFRANÇOIS (UMR INRA-ENSA $\mathrm{EQHC}$ ) pour le traitement et la mise en forme de l'ensemble des illustrations. 


\title{
A GUIDE TO SCALE INTERPRETATION AND AGE ESTIMATION FOR THE EAST-
} ATLANTIC AND WEST-MEDITERRANEAN SHADS (ALOSA SPP.).

\author{
BAGLINIÈRE J.L. (1), SABATIÉ M.R. (1, 2), APRAHAMIAN M.W. (3), \\ ALEXANDRINO P. ${ }^{1}$ (4), APRAHAMIAN C.D. (3), ASSIS C.A. ${ }^{1}$ (5), \\ CASSOU-LEINS J.J. (6), LE CORRE M. (1, 2), MENNESSON-BOISNEAU C. (7), \\ MARTIN-VANDEMBULCKE D. (8), ROCHARD E. (8), TEIXEIRA C. (9)
}

(1) Laboratoire d'Ecologie Aquatique, INRA, 65 rue de Saint-Brieuc, 35042 Rennes Cedex, France.

(2) Laboratoire d'Halieutique, ENSAR, 65 rue de Saint-Brieuc, 35042 Rennes Cedex, France.

(3) The Environment Agency P.O Box 12, Richard Fairclough House, Knutsford Road, Warrington WA 4 1HG, (U.K.).

(4) Animal Genetics and Conservation Unit, Faculdade de Ciencas, Universidade do Porto, Campus Agrario de Vairao, R. Monte Castro 4480 Vila do Conde, Portugal.

(5) Departmento de Zoologia e Antropologia e Instituto de Oceanografia, Faculdade de Ciencias, Universidade do Lisboa, R. Ernesto Vasconcelos, Campo grande, 17000 Lisboa, Portugal.

(6) Equipe Environnement Aquatique et Aquaculture, Laboratoire d'ingénieurie Agronomique, ENSAT, Avenue de l'Agrobiopole, BP. 107 Auzeville-Tolosane, F 31326 Castanet-Tolosan cedex, France.

(7) IBEAS, Faculté des Sciences, Université de Tours, 1 Park Grandmont, 37200 Tours, France.

(8) Unité des Ressources Aquatiques Continentales, CEMAGREF, 50 Avenue de Verdun, 33612 Cestas Cedex, France.

(9) Instituto de Oceanografia, Faculdade de Ciências, Universidade do Lisboa, R. Ernesto Vasconcelos, Campo Grande, 1749-016 Lisboa, Portugal.

\section{ABSTRACT}

The general objective of this guide is to provide a practical manual for interpreting scales and the estimation of age of Alosa from the East Atlantic and West-Mediterranean (Allis shad, Atlantic and Mediterranean shad). Following a brief presentation of the species, populations and rivers studied, the scales, sampling methods and their preparation for reading are described in detail. Definitions and a standard system of notating age are given. The majority of the difficulties encountered in the interpretation of scales are

\footnotetext{
${ }^{1}$ The two teams of Porto and Lisbonne University are included in the project $n^{\circ} 3 / 3 / C . A . / 1981 / 95$ of the programme PRAXIS XXI from the Fundação para a Ciência e Tecnologia.
} 
analysed, solutions proposed and some recommendations given. The whole guide is largely illustrative using examples of typical and atypical scales from the various taxons of the different populations studied.

\section{INTRODUCTION}

Since the end of the 1970's, the eastern Atlantic and western Mediterranean populations of Alosa (Alosa alosa and Alosa fallax sp.) have been the subject of a number of studies aimed at restoring, conserving and protecting the various stocks. The species have (1) a very restricted spawning range and (2) like other migratory species are of (BAGLINIĖRE, 2000) :

- Social and economic importance ; for example, in France, they are an important commercial species with between 500 and 1000 tons of Alosa caught annually. In recent years their popularity as a sport fish has developed in most of the large French rivers.

- Scientific interest, in particular for those studies concerned with evolutionary biology, speciation and hybridization.

- Ecological importance as a good indicator of the biological, physical quality and of the function and form of the lower and middle reaches of large river systems. This arises because alosids tend to home to their natal river, have a poor ability to negotiate obstructions (weirs/barrages) and because the populations are all self-sustaining (not artificially maintained).

An understanding of the biology and ecology of a species is dependent on knowledge of demographic characteristics, in particular the age structure of the population. In most instances the estimation of age is determined using hard parts of the skeleton which show periods of fast and slow growth, predominantly the scales. However, scale measurement studies in Alosa are more difficult when compared to those commonly performed on migratory salmonids (BAGLINIĖRE, 1985 ; RICHARD and BAGLINIĖRE, 1990 ; ELLIOTT and CHAMBERS, 1996). There is therefore a need to standardise the criteria used for estimating age in Alosa.

The standardisation of the criteria used to interpret, describe and estimate age for Alosa from scales was addressed at a workshop in Rennes (France), between the $1^{\text {st }}$ to $3^{\text {rd }}$ December 1997 . The workshop was attended by most of the scientists currently involved in studying the biology and ecology of Alosa from the eastern Atlantic and western Mediterranean. At the workshop scales from three species (Alosa alosa, Alosa fallax fallax and Alosa fallax rhodanensis) and from several different countries ranging from the eastern Atlantic to the western Mediterranean, were examined and compared.

This paper summarises the problems and difficulties encountered in estimating age for Alosa. It proposes definitions, solutions and advice using both typical and non-typical case studies.

\section{INTRODUCTION TO THE RIVER SYSTEMS AND ALOSA POPULATIONS STUDIED}

The Alosa populations studied came from ten rivers located in the eastern Atlantic and western Mediterranean, ranging from England $\left(52^{\circ}\right.$ lat. $\left.\mathrm{N}\right)$ to Morocco $\left(34^{\circ}\right.$ lat. $\left.\mathrm{N}\right)$; and including the rivers Severn, Loire, Dordogne, Garonne, (indeed Gironde : common estuary of Garonne and Dordogne), Rhône, Lima, Tage, Zezere (tributary of the Tage), Guadiana and Oued Sebou (Table I). 
The anadromous form of the twaite shad (Alosa fallax fallax) can be found in most of the rivers which drain into the Atlantic Ocean. This species is also present in the western Mediterranean as a taxon, morphologically distinct from Alosa fallax fallax and identified by QUIGNARD and KARTAS (1977), as the sub-species of twaite shad (Alosa fallax rhodanensis). The Mediterranean twaite shad is unique for two reasons : 1 . The subspecies is meristically and genetically similar to Alosa fallax fallax, and the rank of subspecies has yet to be confirmed genetically (LE CORRE et al., 1998) and 2. is larger at maturity and has a greater capacity to migrate longer distances into fresh water, similar to the allis shad (Alosa alosa) (LE CORRE et al.,2000).

The migratory form of the allis shad (Alosa alosa) is no longer present in the Severn and Oued Sebou, in the case of the latter the species disappeared in the early 1990s. In the Tage, the allis shad still appears to be present, but the population is probably very small. However, a landlocked population has developed in one of the tributaries (River Zezere). This population was created as a result of a dam (Castelo de Bode) being constructed at its confluence with the River Tage 40 years ago (ALEXANDRINO, 1996). On the French side of the Mediterranean allis shad is considered rare (ROULE, 1924). It seems to have completely disappeared from the Rhône (LE CORRE et al., 1997) in to which it was introduced via the Dordogne river in the middle of the twentieth century (HOESTLANDT, 1958). Table I.

General information about the biology of the different populations are given in

For allis shad, despite inter-year variability there exists a constant gradient in terms of growth rate from North to South of the species range. At the southern end of their range (Lima and Oued Sebou) their growth rate is higher (SABATIÉ 1993, SABATIÉ et al. 1996) when compared with the Douro and Mondego populations from Portugal (EIRAS, 1981 ; ALEXANDRINO, 1996). For more northern populations the growth rates are similar with the population from the Loire being intermediate between those from the GirondeGaronne-Dordogne system and those from the Adour (MENNESSON-BOISNEAU et al., 2000).

In the twaite shad the size and weight characteristics of the different Atlantic populations were similar ; with a couple of exceptions. The Tage population are distinct because of their small size while the Lima population is the largest of the various Atlantic populations (ALEXANDRINO, 1996) and those from Morocco show a better growth rate only during the first year (SABATIÉ, 1993). In contrast, compared to the Atlantic stocks, the Mediterranean populations (Rhône, Aude and Hérault) have a greater range in size and weight and exhibit a faster growth rate (DOUCHEMENT, 1981 ; LE CORRE et al., 2000).

\section{DESCRIPTION OF ALOSA SCALES}

European Alosa scales have been described by several authors (HASS, 1965 ; BERG, 1966 ; CASSOU-LEINS and CASSOU-LEINS, 1981 ; DOUCHEMENT, 1981 ; APRAHAMIAN, 1982 ; BAGLINIĖRE and LE LOUARN, 1987 ; MENNESSON-BOISNEAU and BOISNEAU, 1990). Scales are cycloid, characteristic of clupeids. The anterior portion of the scale is polygonal, with a slight dome, in shape (Figure 1). The shape of the scale can be modified as a result of erosion and/or absorption, associated with the return of the fish to fresh water for spawning. The scale ceases to be polygonal and becomes more oval in shape, much of the dome can disappear and the size of the scale can be reduced by 30 $40 \%$ when compared to its size prior to spawning. The focus or centre of the scale is offcentre towards the posterior part of the scale. 
(Figure 1):

Four characteristic marks can be observed on the anterior portion of the scale

* basal line ; that is the first circulus separating the anterior and posterior fields of the scales; it can cut across the focus.

* transverse grooves which are strongly marked and present in all areas of the scale. They cut across the two other features.

* very thin and narrow striations corresponding to circuli. These circuli are drawn in a relatively transverse way across the scale but are more concentric at the edge. The striations are absent from the posterior part of the scale.

* Concentric rings only on the lateral and anterior fields of the scale. They represent the growth rings (annuli).

\section{SCALE MEASUREMENT EXAMINATION}

\section{Scale sample, preparation and presentation}

A standard area for scale sampling has been defined for the adult fish (Figure 2). In this zone the scales are more symmetrical, there is a lower percentage of replacement scales and the scales are generally more readable (growth rings are clearer and there is less chance of the annuli being obscured by spawning marks). In general terms, this zone is situated in the middle of the body reaching from one side to the other of the mid line. However the precise location of this standard zone varies slightly between species.

In the allis shad, the optimum zone for taking a sample is situated above the mid line, between the posterior tip of the dorsal fin and the anterior tip of the anal fin (MENNESSON-BOISNEAU and BOISNEAU, 1990). In contrast, for the twaite shad, it is located from the vertical projection of the anterior tip of the dorsal fin to 2-3 rows below the mid line (APRAHAMIAN, no published observation; ASSIS, no published observation).

There have been no studies, which have aimed at standardising the area for scale sampling from hybrids or for adult Mediterranean twaite shad. Until now, the scales of these two groups have always been sampled from the standard zone defined for allis shad. However, it would seem preferable in the future for the Mediterranean species to use the area defined for the Atlantic twaite shad. This is because the individual spawning marks, of which there may be many, are clearer and can more easily be counted. For hybrids, the use of either of the two zones will be a function of how easy it is to read the scales of the fish. For the juvenile and immature stages the standard area for taking scales has yet to be determined. However, it is always difficult to remove some scales from juvenile shads because of their great delicacy (there is a large loss of scales at capture).

It is recommended that between six and 20 scales are sampled from a small site within the standard area. For older fish a minimum of six are recommended, none of which should be replacement scales, selection should be made using a binocular microscope.

It is imperative that the scales are cleaned. They can be cleaned dry by rubbing between two fingers, in water using a bath of very dilute solvent ( $5 \% \mathrm{KOH}$ or Trypsine) for no longer than three minutes, and then a fine paint-brush. Cleaning can also be carried out using an ultrasonic method, which would seem to be quicker and more efficient than the other methods but this has to be confirmed. After cleaning, scales can be read directly or placed between two glass slides (at least per fish). Plastic film impressions of the scale are not recommended, as the scale's structure cannot be easily observed on film. 
Optical instruments are generally used to read and interpret scales, it is necessary to magnify the scales between $10-50 \mathrm{x}$; using a microfiche reader or Projectina. CASSOU-LEINS and CASSOU-LEINS (1981) reported that microradiography (X-ray) was more effective in identifying the annuli in allis shad (Figure 3). However studies using this technique on scales from Alosa from the Rhône carried out in collaboration with F.J. MEUNIER (Laboratoire d'Ichtyologie générale et appliquée du Museum National d'Histoire Naturelle de Paris) were unsuccessful. It is difficult to know why this was the case.

\section{Preliminary definitions}

\section{Annulus or winter ring}

The annulus corresponds to a structural discontinuity surrounding the scale, more often appearing as a crease, cut or fusion of the circuli (BAGLINIËRE et al., 1992). If this general definition is true for Alosa (CASSOU-LEINS and CASSOU-LEINS, 1981 ; DOUCHEMENT, 1981), it must be extrapolated due to the variability in the morphology and in the intensity of the annulus observed between the various species (MENNESSONBOISNEAU and BAGLINIĖRE, 1992). Thus, an annulus may be described as a white / clear line running parallel to the border of the scale (Figure 4a), showing concentric thin striae whose width increases from the centre outwards. The striae are cut by the annuli and the ends don't overlap perfectly. The line is generally visible all around the scale, particularly the lateral and anterior fields (Figure $4 b$ and $4 c$ ). Some annuli are only slightly marked and appear as a white line only apparent because of a distortion and/or a difference in width, or a waviness but no break of the thin striae, usually only easily visible under high magnification (Figure 5). In contrast, other strongly marked annuli, possess very wide white bands with or without distortion of the thin striae (Figure 6).

\section{Spawning marks}

The spawning or reproduction mark appears as a continuous concentric line more or less opaque, variable in width and overlapping the thin striae (Figure 7). Between the reproductive mark and the edge of the scale two types of thin striae can be observed. The types reflect different levels of distortion (erosion / absorption) of the scale (1) those which run parallel to the reproduction mark, corresponding to a minor distortion (Figure 8) and (2) island-like aggregations of striae, impregnated with large white swirls corresponding to strong structural disorganisation (Figure 9). As a general rule, anadromous allis shad are semelparous as such a reproduction mark is seldom observed (a maximum of $5-6 \%$ of the Atlantic stock spawn more than once). However landlocked populations of allis shad can spawn more than once, as a consequence numerous spawning marks may be present. For twaite shad approximately $30 \%$ of the adult Atlantic and Mediterranean populations have a spawning mark on their scales, indicating an iteroparous life history (MENNESSON-BOISNEAU et al., 2000). Of the two species the spawning mark in anadromous allis shad is more marked than is the case for lacustrine populations and twaite shad (see Figures 7, 8 and 9).

\section{Anniversary or birth date}

The anniversary date for allis and twaite shad should correspond to the median reproduction date as opposed to the start date of the freshwater phase of their spawning migration. The median date varies both between and within species with the latitude of the river and where in the river the fish spawn. The date can vary from the $1^{\text {st }}$ May for the Moroccan Alosa (SABATIÉ, 1996) to the $15^{\text {th }}$ May for allis shad of the Lima (SABATIÉ et al., 1996) to the $1^{\text {st }}$ July for allis shad in France (CASSOU-LEINS and CASSOU-LEINS, 1981; DAUTREY and LARTIGUE, 1983; MENNESSON-BOISNEAU et al., 1986 ; TAVERNY, 1991). The median date for twaite shad can range between $1^{\text {st }}$ June for the populations from the Rhône (LE CORRE et al., 1997) and Severn (APRAHAMIAN, 1982) 
to $1^{\text {st }}$ July for the Loire (MENNESSON-BOISNEAU and BOISNEAU, 1990). Because of these differences, no universal anniversary date can be used, only the anniversary date of the population being studied, if it is known. If the median date is not known it is suggested that the date from a geographically close population of the same species be used.

In contrast to anadromous stocks, it is possible to use a universal anniversary date as the date of annulus formation for lacustrine (landlocked) populations of Alosa alosa and Alosa fallax.

\section{Date of annulus formation}

The date of annulus formation has been mainly studied in juvenile shad. The date the first annulus appears on the scales is dependent on the latitudinal position of the population. Thus it can appear from the middle to the end of winter for the more southern stocks (SABATIÉ, 1993 ; ASSIS, no published observation), to between May and June for lacustrine and northern populations (BERG, 1966 ; APRAHAMIAN, 1982 ; TAVERNY, 1991).

This means that no universal anniversary date can be used. The first annulus is visible after approximately 9.5 and 10.5 months of age for allis and twaite shad, respectively. Further information is needed on the precise date of appearance of the first annulus which can be achieved through a study of the marginal growth of scales over time and how this varies between different rivers, populations and species.

\section{Age notation}

The total age is determined by adding the total number of annuli and spawning marks on the scales. For alosoids, unlike the migratory salmonids (BAGLINIERE, 1985) it is not possible to distinguish between the fresh water and sea water phase of their life history as the first winter ring generally appears after the fish have left fresh water (TAVERNY et al, 2000). For fish at the start of the freshwater phase of their spawning migration it has been agreed that the edge of the scale be considered as an annulus, even if the annulus is not visible. In this particular case it has been assumed that that part of the scale laid down between the previous annulus and the edge corresponds to true annual growth (do not take into account the translucent part on the edge). Thus the total age is the sum of the number of annuli plus one for the scale's edge. It has also been agreed that the notation should have, if possible, an exponent corresponding to the number of previous spawnings. Thus, if a fish is notated 4 , it is four years old without any other indication. If it is notated $4^{\circ}$, it is four years old and a virgin (fish spawning for the first time) and finally if the fish is notated $4^{n}$, it means that it is aged four and it has spawned $n$ times. When estimating the number of spawners within the population, information should also be obtained on the date and site of capture, the maturation status of the gonads and the degree of scale erosion. A simple method for estimating the degree of scale erosion could be to analyze the scale form index (largest longitudinal diameter/largest transverse diameter (BURDAK, 1986)) during upstream migration. Those cases where fish have marked "plus" growth on their scales and are not close to their anniversary date should have a " + " assigned to their age (Figure 10). As it is not possible to consider the fish to be one year older.

\section{The percentage of adult fish which could be aged}

The percentage of adult fish, which could be aged, is presented for some of the populations analysed at the workshop in Table II. The percentage is generally high and in part reflects that scales had been specifically chosen for reading and thus no replacement scales were present. The percentage decreases with age and affects females more than males as they are on average older. The main reasons why an age could not be assigned 
to a scale were ; too many marks (true annuli, spawning marks and supernummary marks) the absence of marks, erosion on the scale's surface and /or severe erosion on the scale's edge.

\section{Some typical scale examples}

Scales from both species of Alosa, where the age could be unambiguously interpreted, are presented in Figures 11 to 45 . The examples were taken from a variety of different populations, both anadromous and lacustrine, and from fish over a wide range in both size, age and spawning history. All fish of which scales are presented have been caught before the anniversary date. Fork length ( $F L, m m)$ expressed in millimeters was related to total length (TL, $\mathrm{mm}$ ) by the relationship : $\mathrm{FL}=\mathrm{TL}-60$ (MENNESSONBOISNEAU et al., 1986).

\section{Some of the difficulties encountered, proposed solutions and recommendations}

\section{Generalities}

The difficulties encountered in estimating age varied between species, between populations of the same species, with the age of the fish (and so with sex see paragraph the percentage of adult fish which could be aged) also between scales from the same fish (hence the recommendation to remove six scales at least).

In general, scales from twaite shad were easier to interpret than those from allis shad, similarly those from younger fish were easier to read than those from older individuals (MENNESSON-BOISNEAU and BOISNEAU, 1990) and those from females easier than from males (APRAHAMIAN, no published observation). Twaite shad live longer and grow slower than allis shad; the maximum age of twaite shad from the Severn was 13 years old compared with 8 years for allis shad from France or Morroco. The difference between the two species is considered less to do with their longevity and more to do with their slower growth rate. (It needs to be mentioned that at the workshop the scales from the Severn population of twaite shad had been selected to illustrate the various characteristics of the population). However, there are two exceptions to this general rule : 1. In the Moroccan populations, the scales from allis shad were easier to read when compared with those from twaite shad (SABATIÉ, 1993) ; 2 . The scales from the twaite shad population in the Rhône were the most difficult, of all the samples available at the workshop, to age. This may be related to their growth rate which is faster when compared with other populations of twaite shad.

\section{Difficulties and solutions to help with a correct age estimation}

The main difficulties encountered during the workshop are outlined below together with possible solutions to the problem.

- The presence of supplementary / supernumary marks.

They can be found more or less close to the true winter mark (annuli). Where the supernumary mark appears close to the winter ring it gives an appearance of a double ring (more or less large) (Figures 11, 46 and 47). This supernumary ring has been observed on the scales of both species of Alosa from France (DOUCHEMENT, 1981 ; MENNESSONBOISNEAU and BOISNEAU, 1990) (Figures 14 and 48). It can be distinguished from the true annuli as it is not visible on the scales of all individuals from the same cohort or from the same population. Its frequency of occurrence would seem higher in twaite shad than in allis shad (DOUCHEMENT, 1981). In certain populations this double ring structure can run 
over the entire scale, this is particularly the case for the Moroccan twaite shad (SABATIÉ, 1993).

Isolated supernumary rings, can form anywhere on the scale (Figures 27 and 28), even before the first winter mark (e.g. Tage and Oued Sebou populations). On scales of some individuals, from the Oued Sebou, supernumary marks have been observed very close to the scale's centre, these have been termed "spate marks" (SABATIÉ, ibidem) (Figure 49).

As a general rule, the extra marks are distinguishable from age rings in several ways. They very rarely run all around the scale, their structure is less accentuated (wider inflexion and thickness) and they do not start from the base line (except in some cases when observed before the first annulus). However, in some cases, distinction between the annulus and a supplementary ring can remain difficult and otolith examination may not always be a solution (MENNESSON-BOISNEAU and BOISNEAU, 1990).

- The absence of annuli and / or the presence of very slightly marked annuli (Figure 50). This situation can be found in populations of twaite shad from the Mediterranean. However it is rare to observe this phenomenon in all mounted scales. Furthermore, examination using a higher magnification often allows detection of these annuli. In such cases, age determination should be assisted using the otolith.

Within this context, it is important to mention the problem of the absence of an annulus at the edge of the scale even if the scale's edge appears intact. It has been agreed to consider the scale's edge as the last annulus (see age notation). However, this recommendation needs to be checked.

- The existence of a winter scar similar to a spawning mark has been observed frequently in Alosa populations from Morocco and mainly in Allis shad (Figures 6 and 19 (see $5^{\text {th }}$ winter ring)). The winter scar is thought to have arisen as a result of an accident resulting in the erosion of scale material and can therefore be confused with a spawning mark. It can been differentiated from a true spawning mark by close examination (see previous description in text).

- The position of the first winter ring on the scale (Figure 51). From the literature (DOUCHEMENT, 1981) and from the analysis of scales presented at the workshop, it appears that the first annulus is situated between the first and the third transverse groove and that this was independent of species (Figure 52). The second annulus is situated between the fifth and seventh transverse groove. However, the position of the two first annuli could change according to stock. In most cases the second annulus is clearly marked on the scale, as such its position seems relatively easy to locate except in twaite shad from the Rhône and the Tage, where in 22.4 \% of scales its position could not be located.

- The consequence of erosion and/or absorption of scale material (Figure 53). Erosion and/or absorption of scale material is particularly evident on the edge of the scale, but can also occur on the surface. The amount of erosion and/or absorption increases with age and the closer the fish are to spawning. Such a phenomenon can result in the loss of winter rings (annuli) and the total or partial imposition of two spawning marks, and affects mainly twaite shad as they are multiple spawners (Figure 54). It can lead to an underestimate of the age, by up to two years in the allis shad (MENNESSON-BOISNEAU and BOISNEAU, 1990). In this situation, it is better to estimate age from otoliths as they do not show any erosion and/or absorption of material.

- The presence of a winter ring just before or after a spawning mark. Such observations are rare in anadromous populations except in twaite shad from the River 
Tage. However, these observations have been made in some American shad populations (A. sapidissima: KING (pers. comm.)).

The presence of a winter ring after a spawning mark could occur if the fish remained in fresh water for a year (or more) following spawning. This has not yet been observed. As such it was agreed at the workshop that only the spawning mark should be taken as the year-end when estimating age.

The presence of a winter ring before a spawning mark could occur if the erosion of the winter ring is incomplete, preventing the fusion of the winter ring and the spawning mark. Both marks should be taken to represent the same age. Such a situation has been observed in twaite shad from the River Rhône, but is relatively rare in anadromous populations. The situation may however occur more frequently in lacustrine populations (BERG,1966), though has not always been observed in the landlocked population from Castelo do Bode (River Zezere).

\section{General recommendations}

In addition to the different technical solutions proposed, the estimation of age can be improved by having :

- A good knowledge of the biology of either the stock being studied (from juvenile to adult) or more generally of the species being studied throughout its spawning area. In particular, knowledge of longevity, growth rate, the size structure of the mature population, the size at maturity, sex, and migration and spawning (birth date) periods are essential in order to reduce errors. For example a count of all annuli both true (including spawning marks) and false (supernumary) should not end up being non-compatible with what is known about the age structure of the stock.

- A correct use of the definition of a spawning mark and a "false spawning mark" generated by erosion of scale material following an accident. In these situations, it is necessary to analyse the scale under high magnification (x50 or even x100 magnification).

- The use of other hard structures, mainly otoliths. The use of these structures appears to be a useful complementary tool for many shad populations (Loire : MENNESSON-BOISNEAU and BOISNEAU, 1990 ; Garonne and Dordogne : TAVERNY (1991)). Validation experiments for otoliths are still required to correctly identify the first annulus. However, in some populations (Mediterranean (LE CORRE, unpub. data) and Morocco (SABATIÉ, 1993)) otoliths have not been found to be any more reliable than scales. This is thought to be attributable to the fast growth rate in these populations resulting in poor "readability".

- A matrix relating size to age. This should be produced using samples where the age was estimated with a high degree of confidence. This can be constructed either from scale samples or from otoliths.

- Validation of the scale-reading technique (BEAMISH and MCFARLANE, 1983) should be undertaken following the methods proposed by OMBREDANE and BAGLINIĖRE (1992), in particular : Variation in the relative abundance of a cohort over time resulting in a particular cohort being recognisable over time; agreement between the number of winter rings (annuli) and the number of length frequency modes ; comparison with fish of known age (capture-recapture, following fish in captivity (though this is relatively difficult for Alosa)) and by back-calculation of length (or weight) at an earlier age.

There exists some disagreement of the value of back-calculation for two main reasons ; 1 . The difficulty of identifying the annuli in some populations and 2 . The erosion 
of scale material associated with spawning. Comparisons between back-calculated and directly measured lengths have been made by DOUCHEMENT (1981), APRAHAMIAN (1982) and SABATIÉ (1993). APRAHAMIAN (1982) reported no significant difference in the length of fish back-calculated and that measured directly, from fish of the same cohort. In contrast DOUCHEMENT (1981) and SABATIÉ (1993), in a comparison of fish from different cohorts, found that the observed lengths were larger than those back-calculated. It is therefore important to realise that biased results can be generated when backcalculating length at age. This bias can be minimised in two ways :

- the measurement between the focus and the annuli was the same at the time of capture as it was when it was formed; that the time the annuli was laid down is correct and that the relationship between fish length and scale length is valid agreement with the three validation criteria set out by FRANCIS (1990) ; that for any individual.

- Agreement with criteria relating specifically to shad. These are 1. To measure the total radius of the scale from the focus to the edge where erosion is least (Apex (APRAHAMIAN, 1982)) ; 2. To compare individuals from the same cohort, because of large annual variation in growth ; 3 . In preference, back-calculate lengths of fish using immature fish and adults sampled prior to their first spawning.

\section{ACKNOWLEDGEMENTS}

We are very grateful to Thomas LEFRANÇOIS (UMR INRA-ENSA EQHC) for the processing and the imposition of all illustrations. 


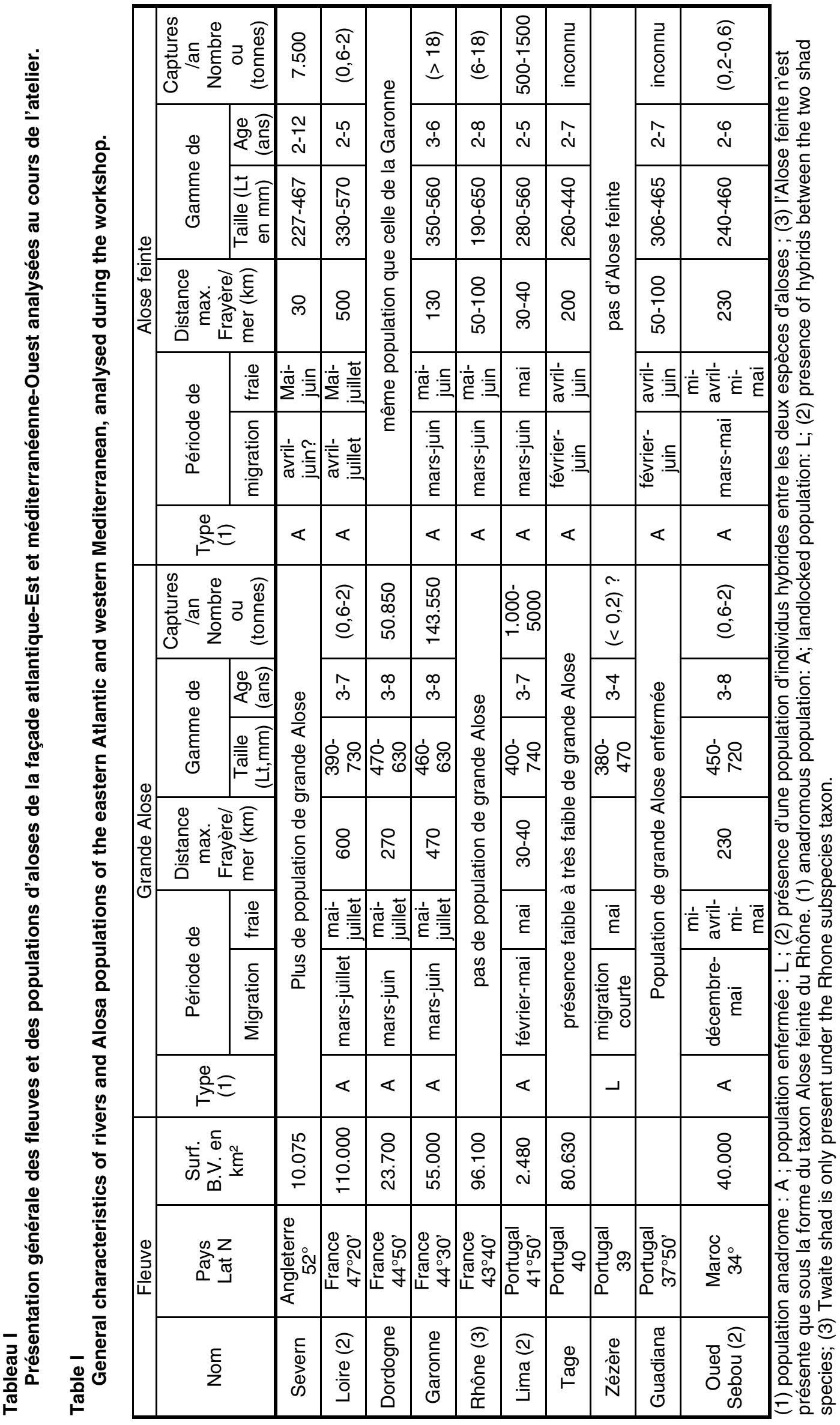


Tableau II

Pourcentage d'attribution de l'âge chez les aloses à partir des écailles d'adultes.

Table II

Percentage of adult fish which could be aged.

\begin{tabular}{|c|c|c|c|c|}
\hline Fleuve & Grande Alose & Alose feinte & hybride & références \\
\hline Severn & & 99 & & $\begin{array}{c}\text { Aprahamian (données non } \\
\text { publiées.) }\end{array}$ \\
\hline Loire & 94 & 97 & 97 & $\begin{array}{c}\text { Mennesson-Boisneau et Boisneau } \\
\text { (1990) }\end{array}$ \\
\hline Gironde & 87 & 83 & & Taverny (1991) \\
\hline Rhône & $96-99$ & & & Le Corre (données non publiées.) \\
\hline Lima & \multicolumn{2}{|c|}{86} & & $\begin{array}{c}\text { Alexandrino (1996) } \\
\text { Tage }\end{array}$ \\
\hline \multicolumn{2}{|c|}{84} & 81 & & $\begin{array}{c}\text { Assis (données non } \\
\text { publiées }\end{array}$ \\
\hline Oued Sebou & $84-95$ & Sabatié (1993) \\
\hline
\end{tabular}

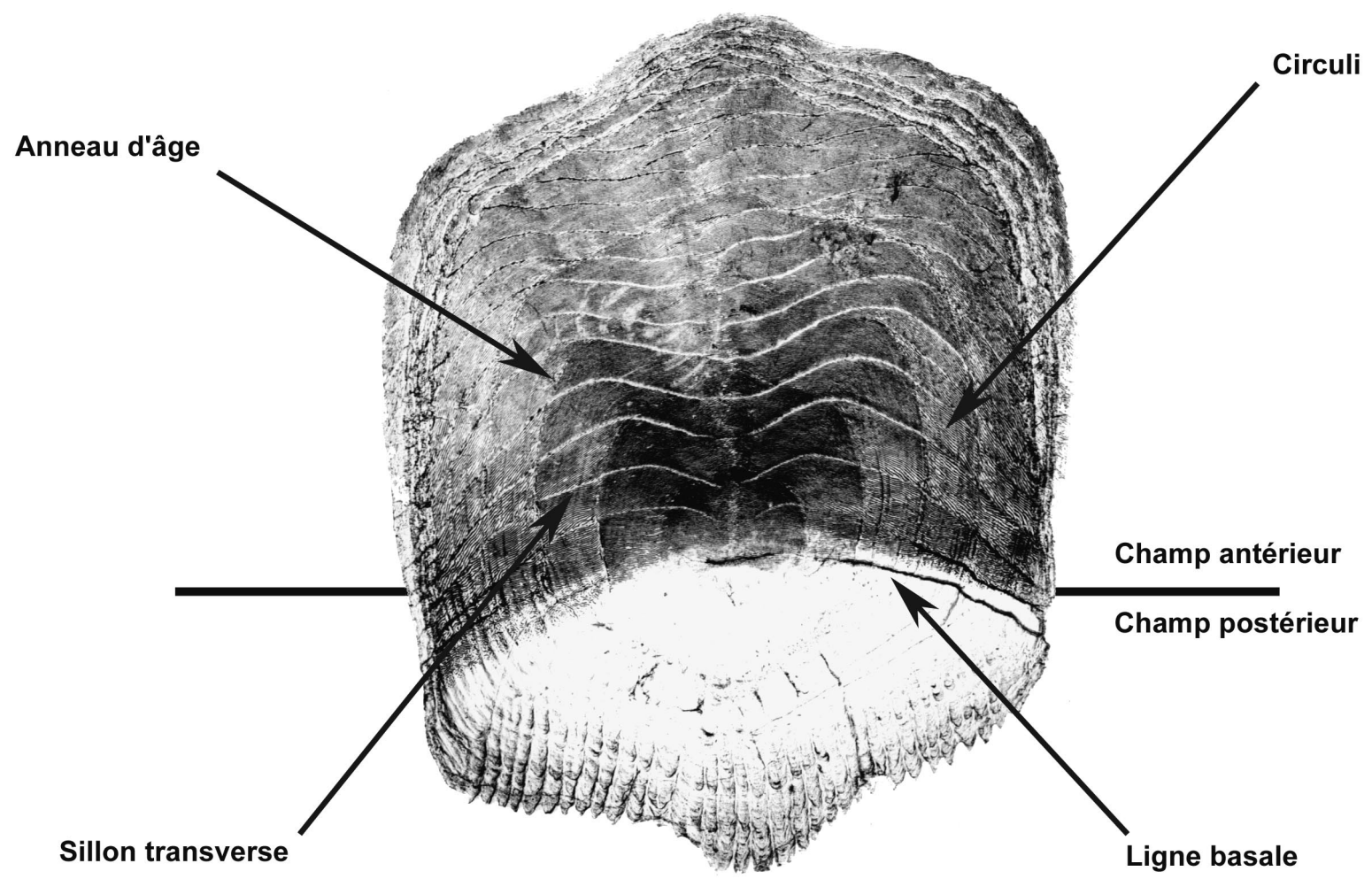

Figure 1

Caractéristiques générales d'une écaille d'Alose (Alose feinte, Severn) (x12).

Figure 1

General characteristics of a shad scale (Twaite shad, Severn) (x12). 


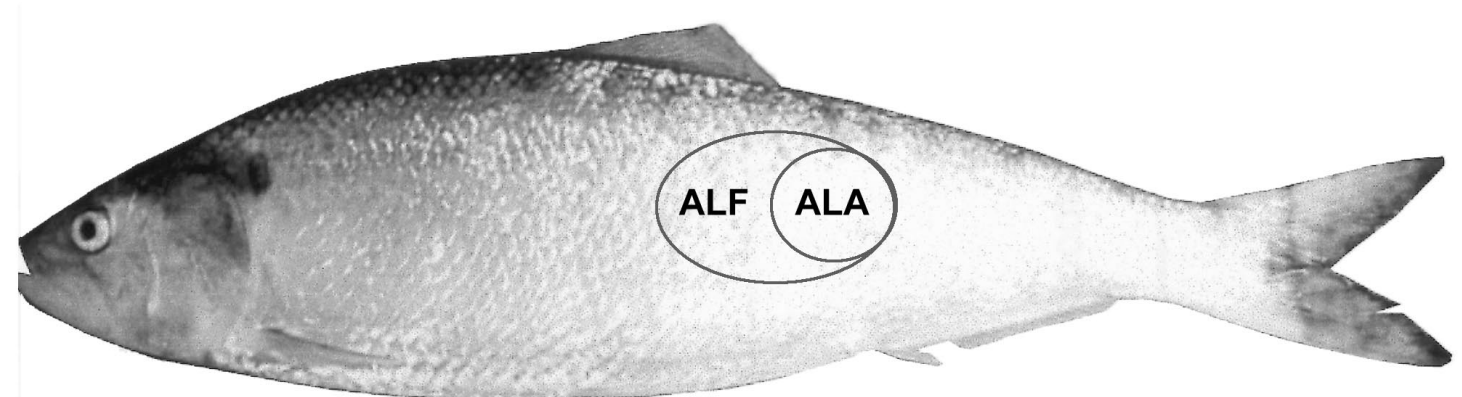

Figure 2

Zone standard de prélèvement d'écailles chez l'Alose adulte (ALA = grande Alose ; ALF = Alose feinte).

\section{Figure 2}

Standard area for scale removing in adult shad (ALA = Allis shad; ALF = Twaite shad).

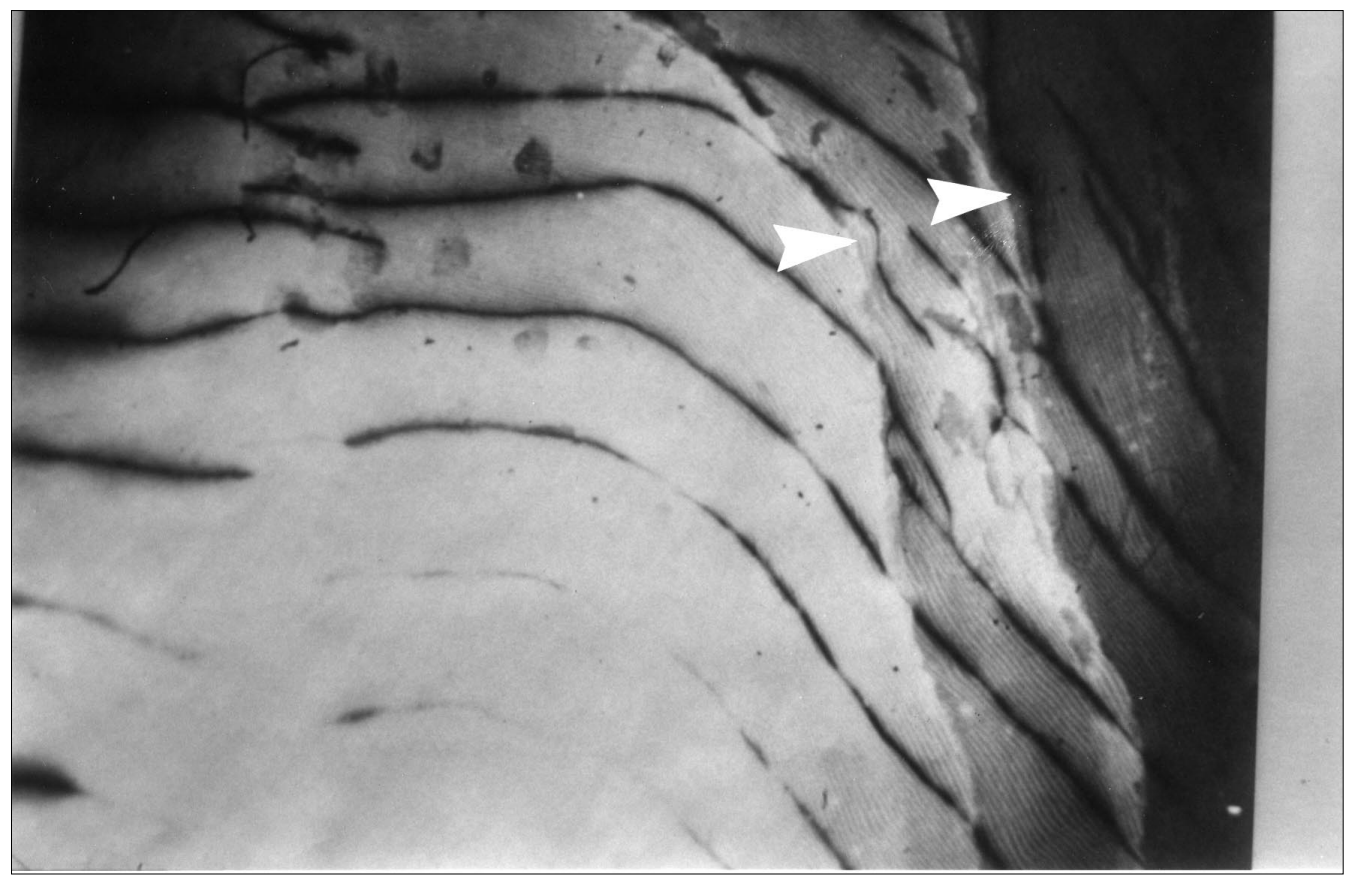

\section{Figure 3}

Identification des annuli $(>)$ par microradiographie (rayons X) (grande Alose, Garonne) (x50).

Figure 3

Identification of annuli ( $>$ ) by microradiography (X-rays) (Allis shad, Garonne) (x50). 
A

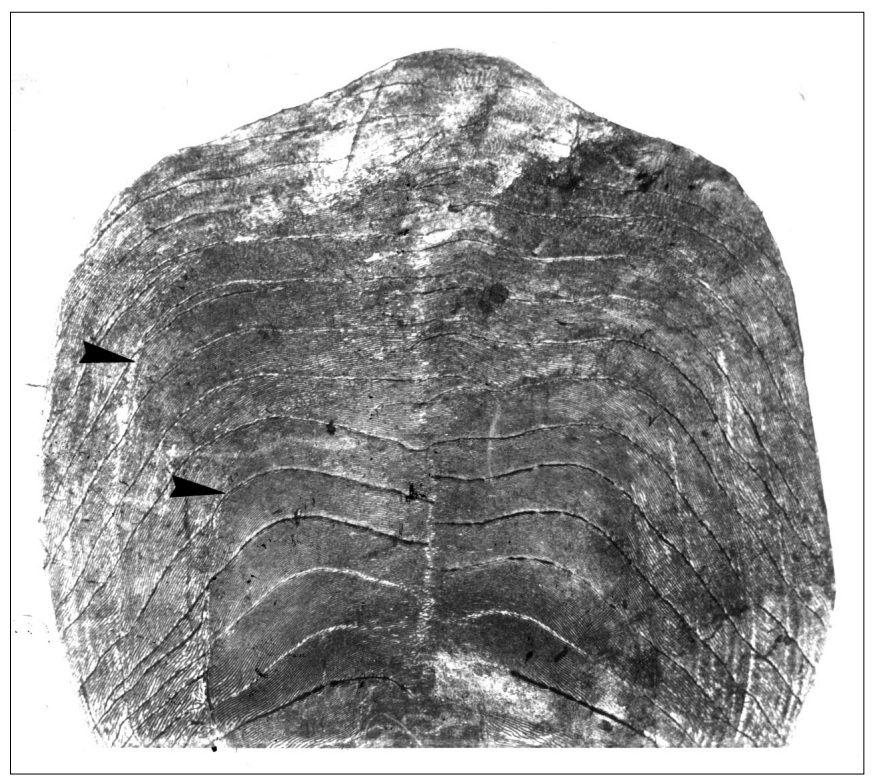

B

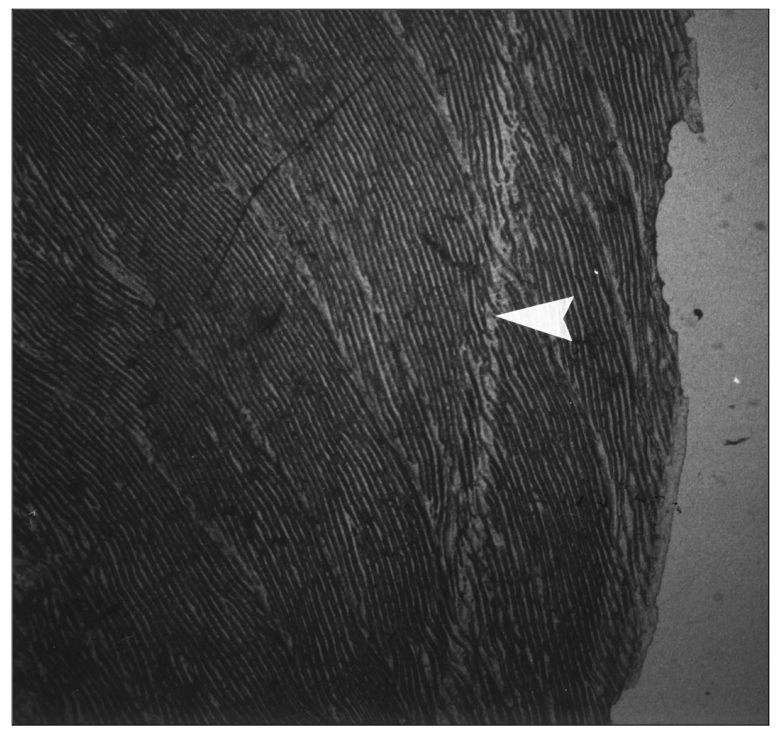

C

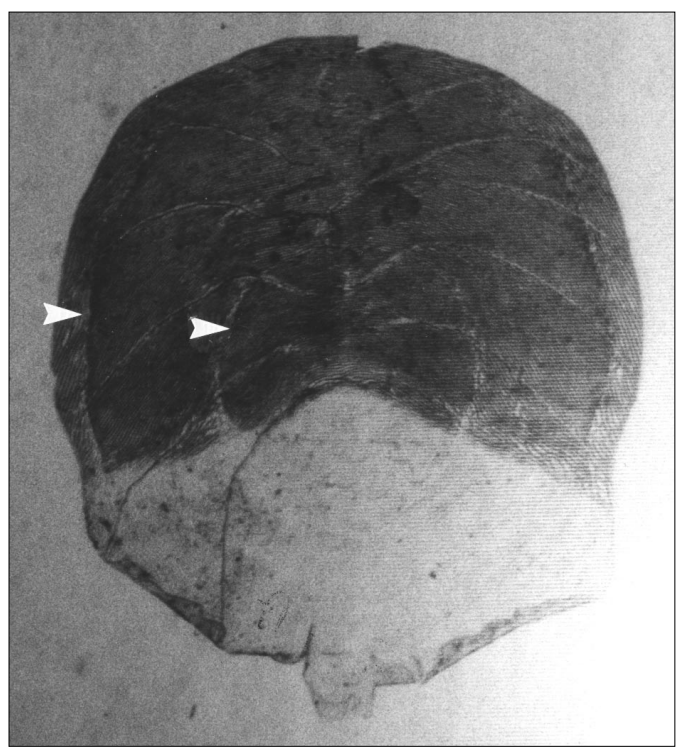

Figure 4

Anneau hivernal typique $(>):(A, \times 10)$ et $(B, \times 30)$ grande Alose, Loire ; $(C, x 15)$ Alose feinte, Tage.

\section{Figure 4}

Typical winter ring ( $>$ ): (A, x10) and $(B, x 30)$ Allis shad, Loire; $(C, x 15)$ Twaite shad, Tage. 
A

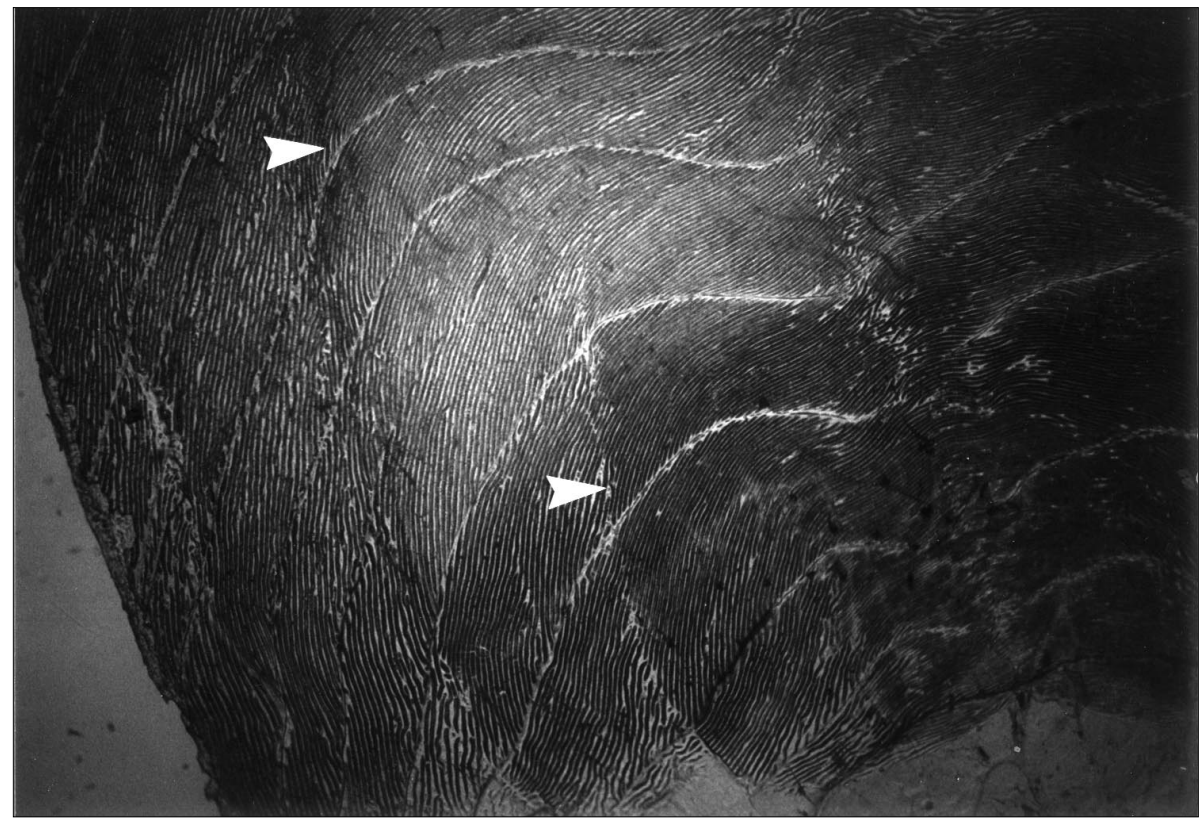

B

\section{Figure 5}

Anneau hivernal plus faiblement marqué $(>)$ : grande Alose, Loire (A, x20) ; Alose feinte, Tage (B, $x 15)$.

\section{Figure 5}

Slightly marked annulus $(>)$ : Allis shad, Loire (A, x20); Twaite shad, Tage (B, x15).

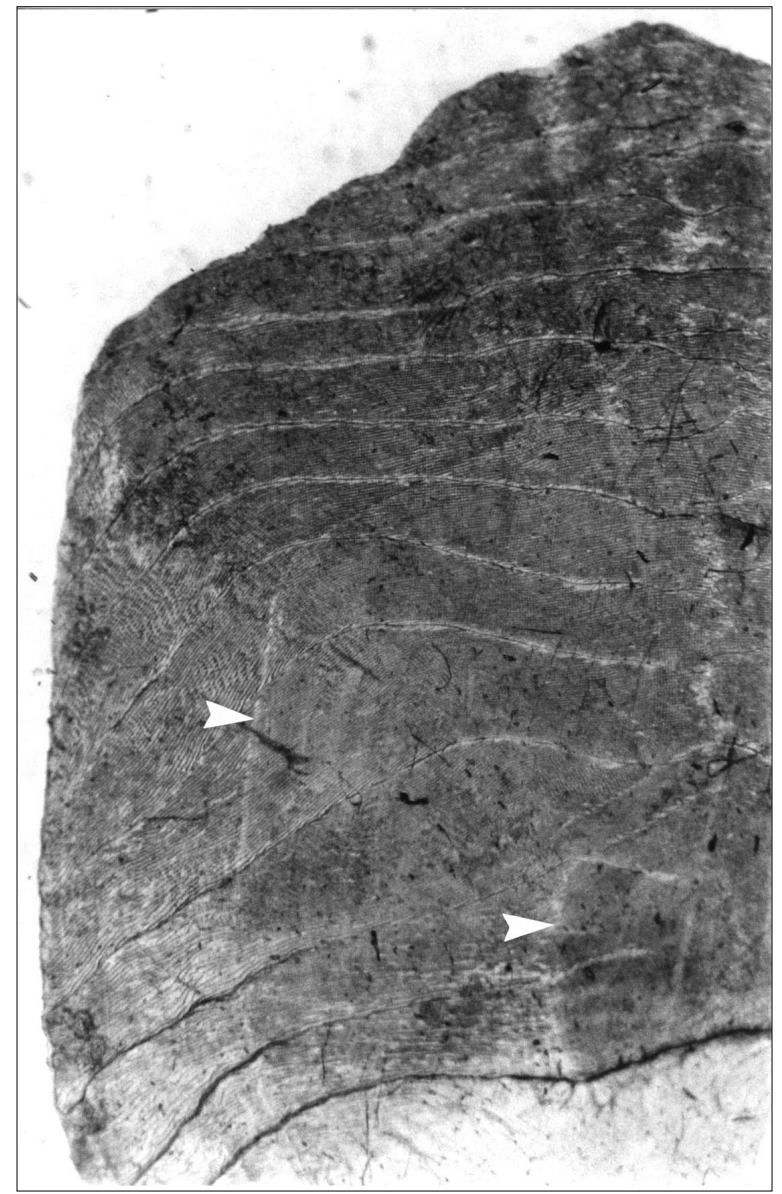


A

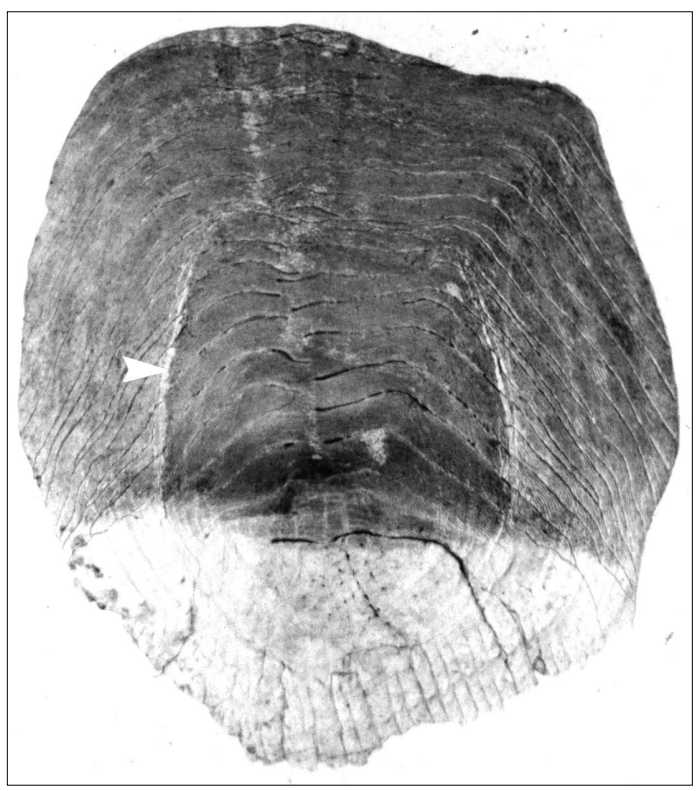

C

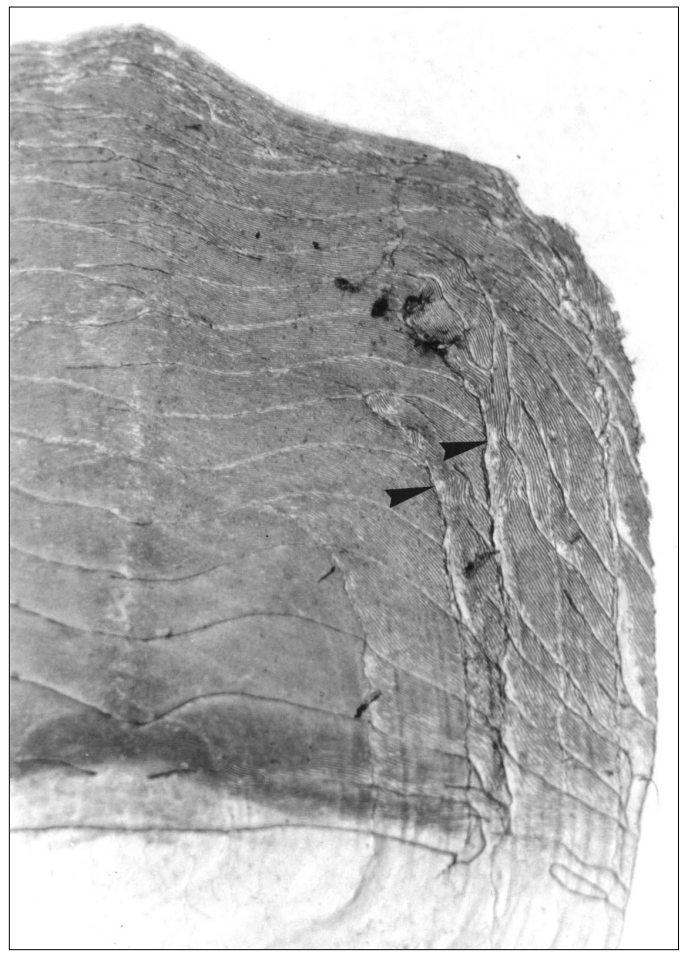

B

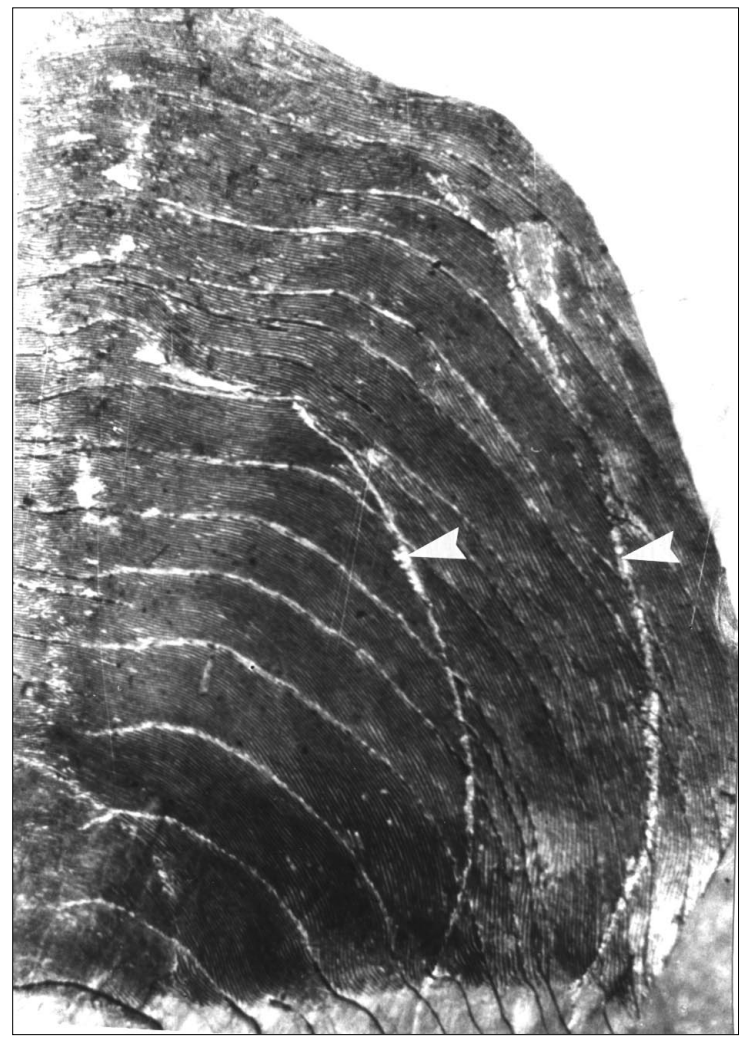

Figure 6

Annuli fortement marqués (marque cicatrice) $(>)$ : grande Alose, Garonne (A, x10) et oued Sebou (B, x20); Alose feinte, Severn (C x16).

\section{Figure 6}

Strongly marked annuli (scar mark) ( $\triangleright$ ): Allis shad, Garonne (A, x10) and oued Sebou (B, x20); Twaite shad, Severn (C x16). 
A

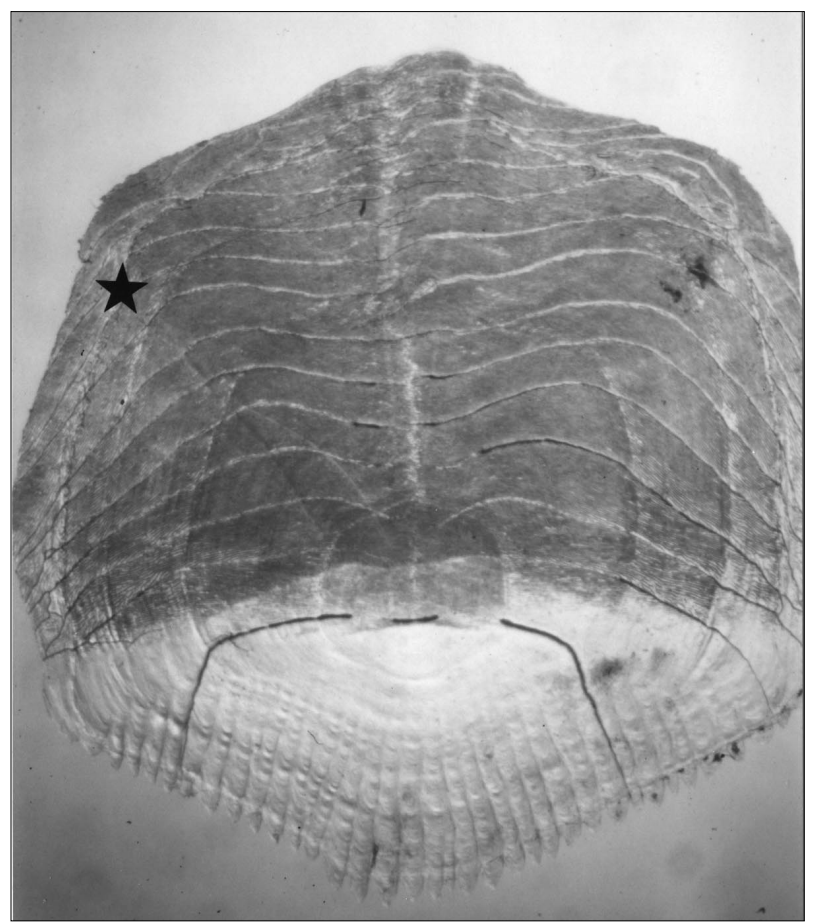

B

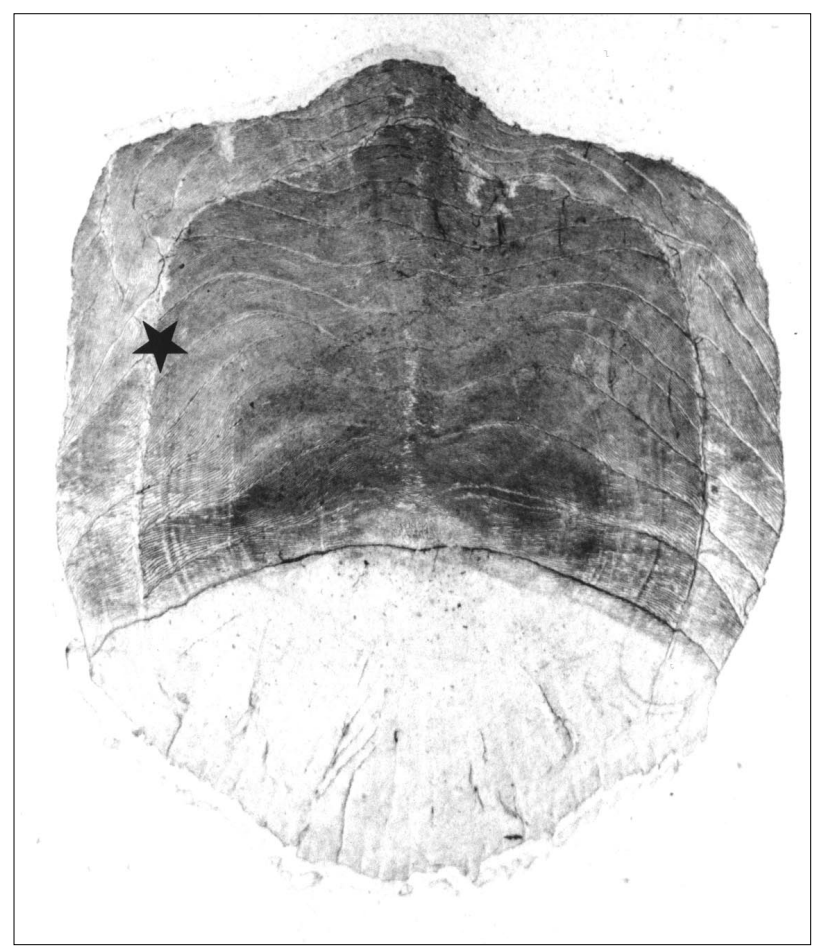

\section{Figure 7}

Marque de reproduction typique ( $\star$ : : Alose feinte, Severn $(A, x 10)$ et Guadiana (B, x10).

\section{Figure 7}

Typical spawning mark ( $\star)$ : Twaite shad, Severn (A, x10) and Guadiana (B, x10). 
B

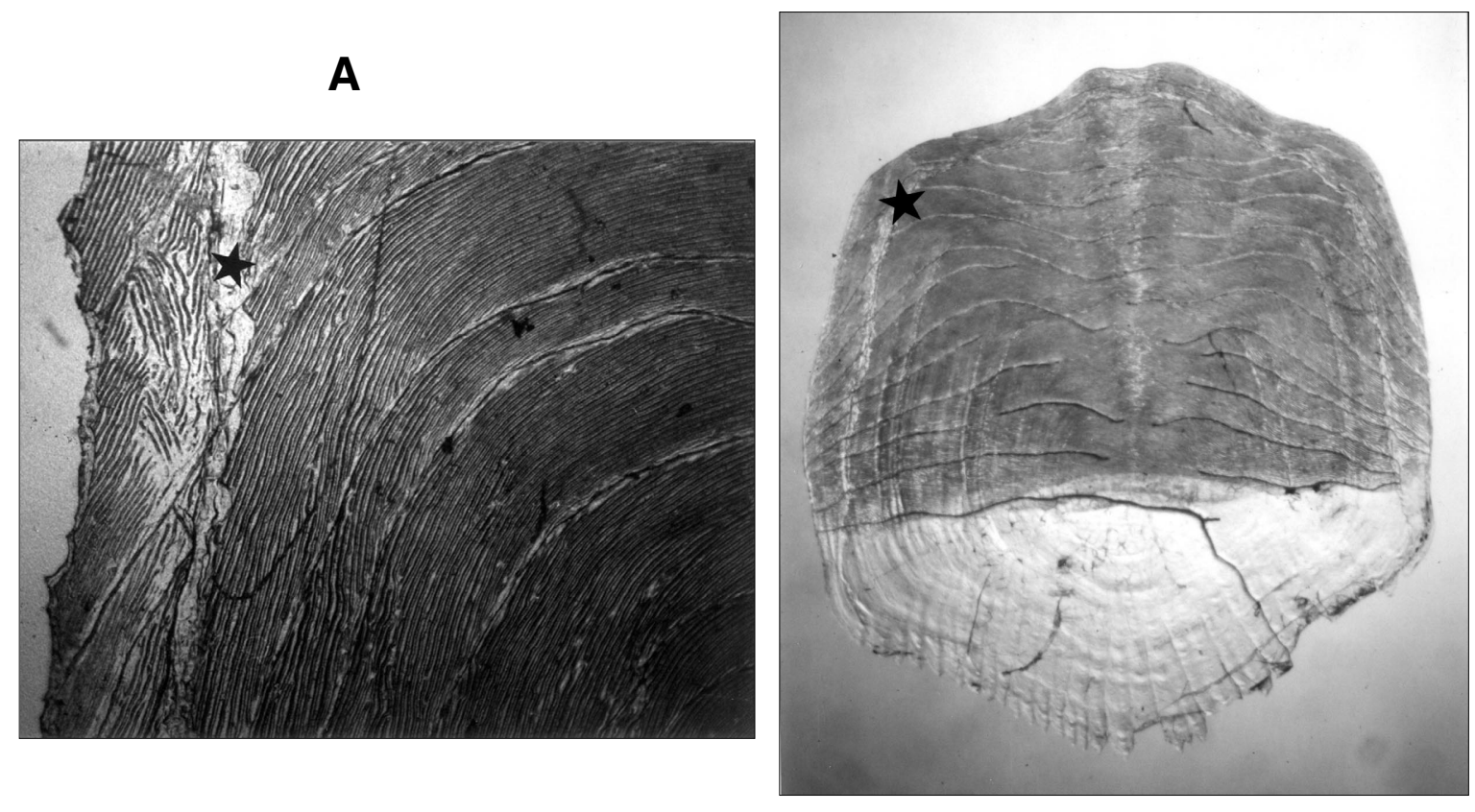

C

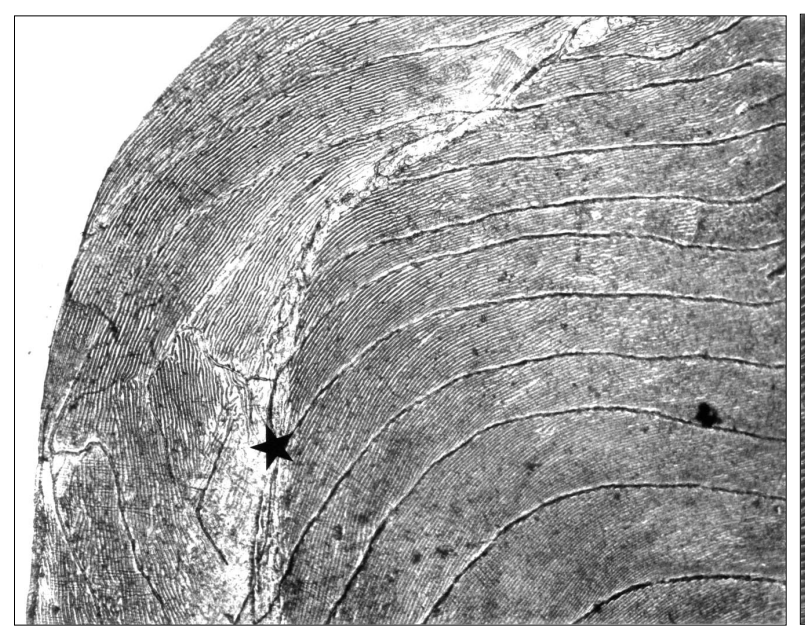

D

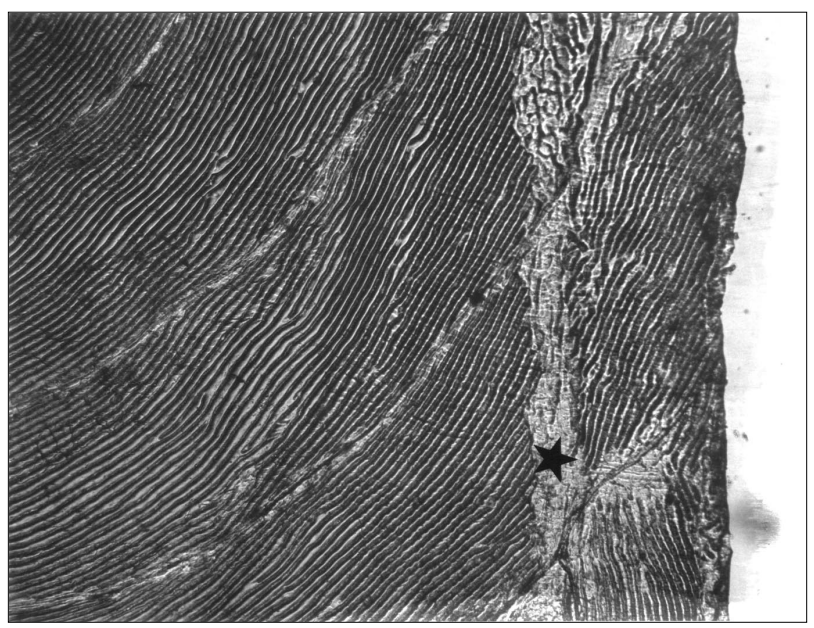

Figure 8

Marque de reproduction $(\star)$ avec une faible désorganisation structurale : grande Alose, Loire (A, x30) ; Alose feinte, Severn (B, x10) et Rhône (C, x20 et D, x50).

Figure 8

Spawning mark $(*)$ with low structural disorganisation: Allis shad, Loire (A, $\times 30)$; Twaite shad, Severn (B, x10) and Rhone (C, x20 and D, x50). 
A

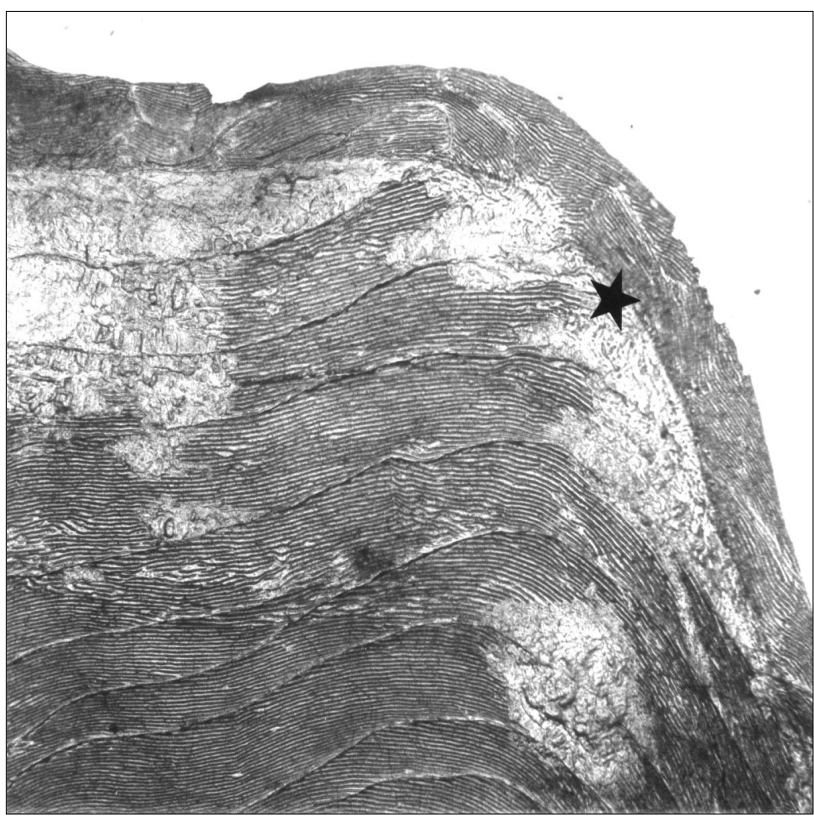

B

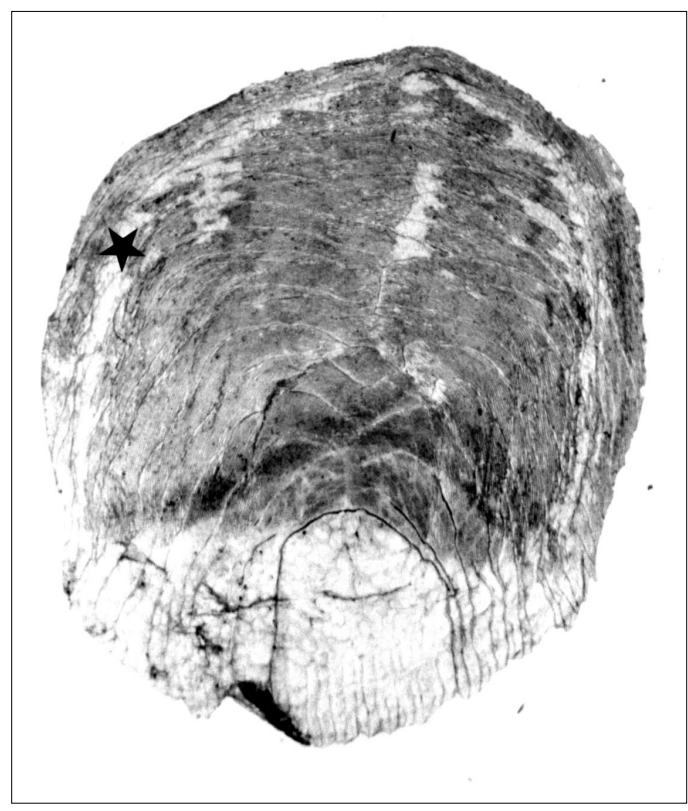

\section{Figure 9}

Marque de reproduction $(\star)$ avec une forte désorganisation structurale : grande Alose, Loire (A, x20) et Gironde (B, x11).

\section{Figure 9}

Spawning mark ( $\star$ ) with strong structural disorganisation: Allis shad, Loire (A, x20) and Gironde (B, x11).

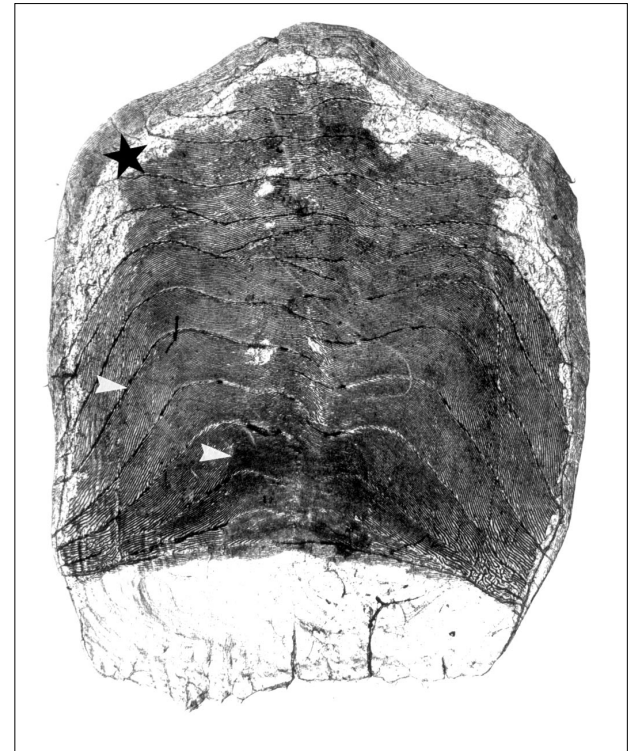

\section{Figure 10}

Grande Alose capturée sur la Loire après la reproduction en novembre et âgée de 3+ans ( $>$ : anneau hivernal, $\star$ : marque de reproduction) $(\mathbf{x 1 0})$.

\section{Figure 10}

Allis shad caught after spawning in November and $3+$ years old $(>$ : winter ring, $\star$ : spawning mark) (x10). 


\section{Légende des figures $n^{\circ} 11$ à 45}

Espèce, fleuve, longueur totale en $\mathrm{mm}$ (longueur à la fourche), sexe ( $M$ : mâle ; $F$ : femelle) et âge (années) ( $>$ : anneau hivernal, $\star$ : marque de reproduction; anneau surnuméraire :O).

\section{Legend of plates $n^{\circ} 11$ to 45}

Species, River, total length in mm (fork length), sex (M: male ; F: female) and age (years) ( $>$ : winter ring, $\star$ : spawning mark, supernumary ring: $\bullet$ ). 


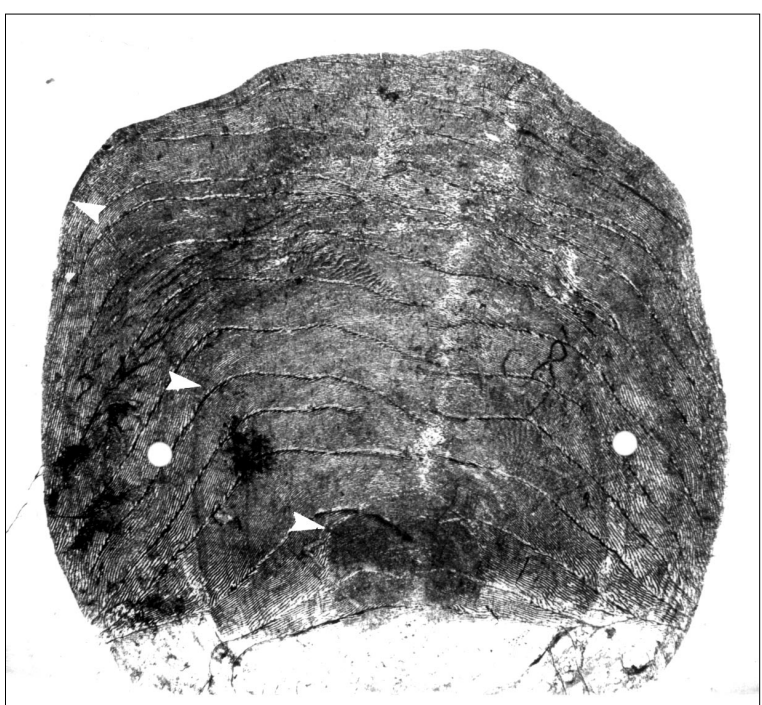

Figure 11

Grande Alose, Loire, (355), M, $3^{0}$ (x10).

Figure 11

Allis shad, Loire, (355), $M, 3^{0},(\times 10)$.

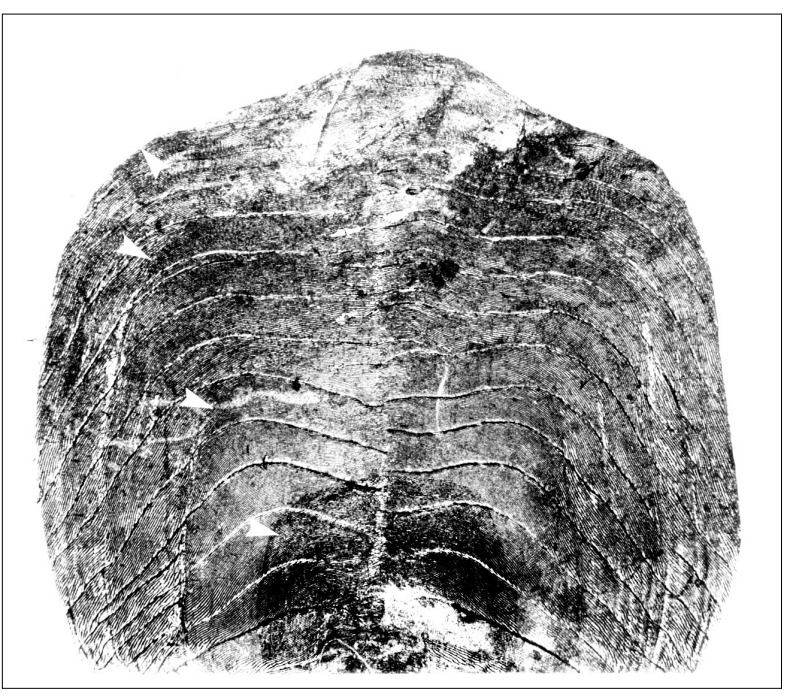

Figure 12

Grande Alose, Loire, (450), M, $4^{0}$ (x10).

Figure 12

Allis shad, Loire, (450), M, $4^{0}$ (x10).

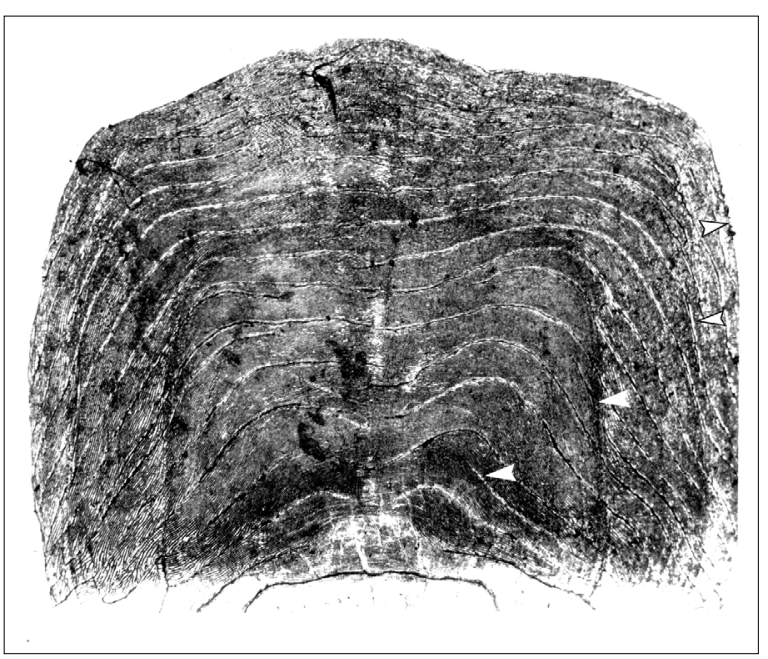

Figure 13

Grande Alose, Charente, 540, F, $4^{0}$, (x10).

Figure 13

Allis shad, Charente, 540, F, $4^{0}$ (x10).

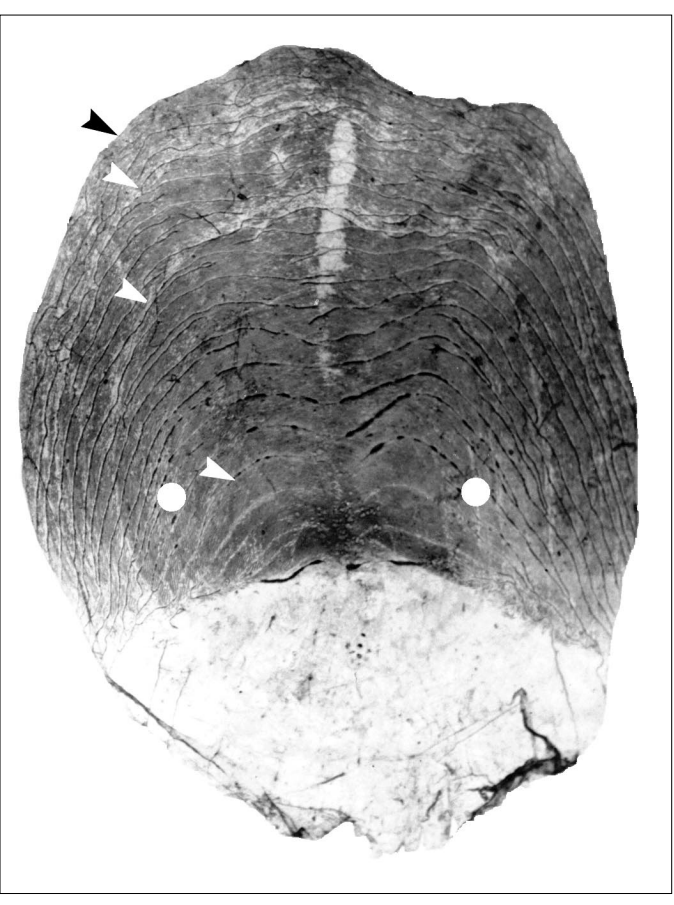

Figure 14

Grande Alose, Garonne, 540, F, $4^{\circ}$ (x6).

Figure 14

Allis shad, Garonne, $540, \mathrm{~F}, 4^{0},(\times 6)$. 


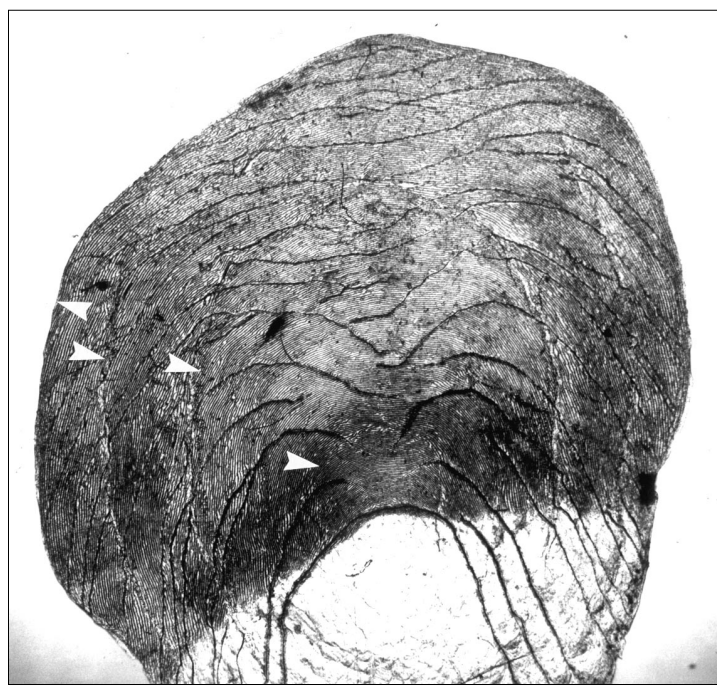

Figure 15

Grande Alose, Lima, 450, M, $4^{0}$ (x10).

Figure 15

Allis shad, Lima, 450, M, $4^{0}$ (x10).

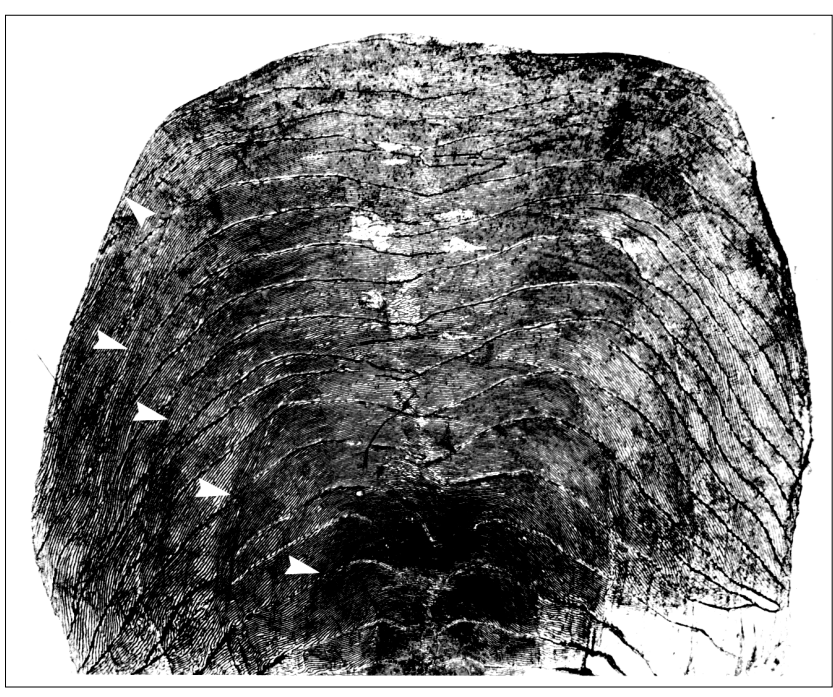

Figure 16

Grande Alose, Charente, 555, F, $5^{0}$ (x10).

Figure 16

Allis shad, Charente, $555, \mathrm{~F}, 5^{\circ}$ (x10).

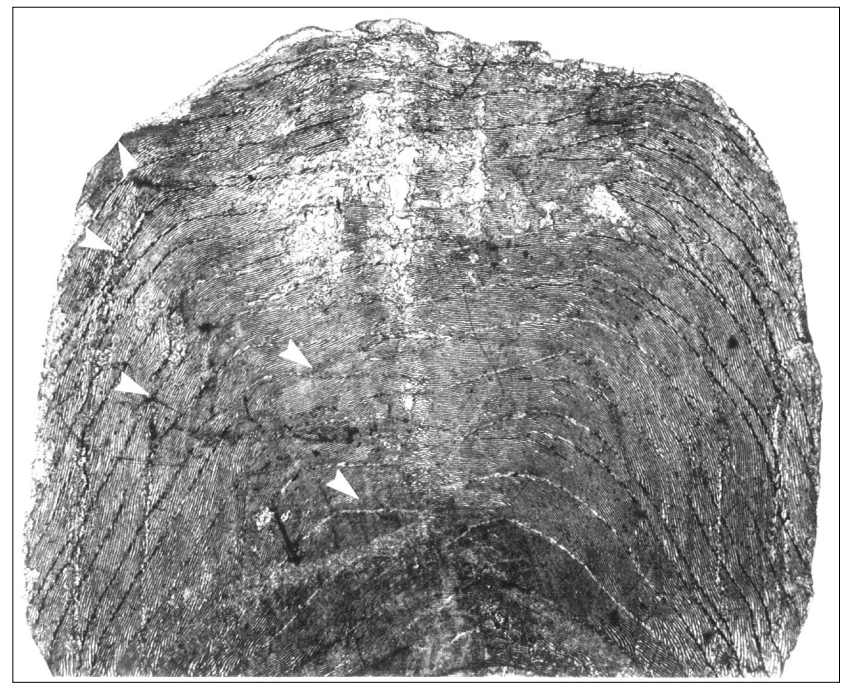

Figure 17

Grande Alose, Oued Sebou, 645, F, $5^{\circ}$ (x10).

Figure 17

Allis shad, oued Sebou, 645, F, $5^{0}$ (x10).

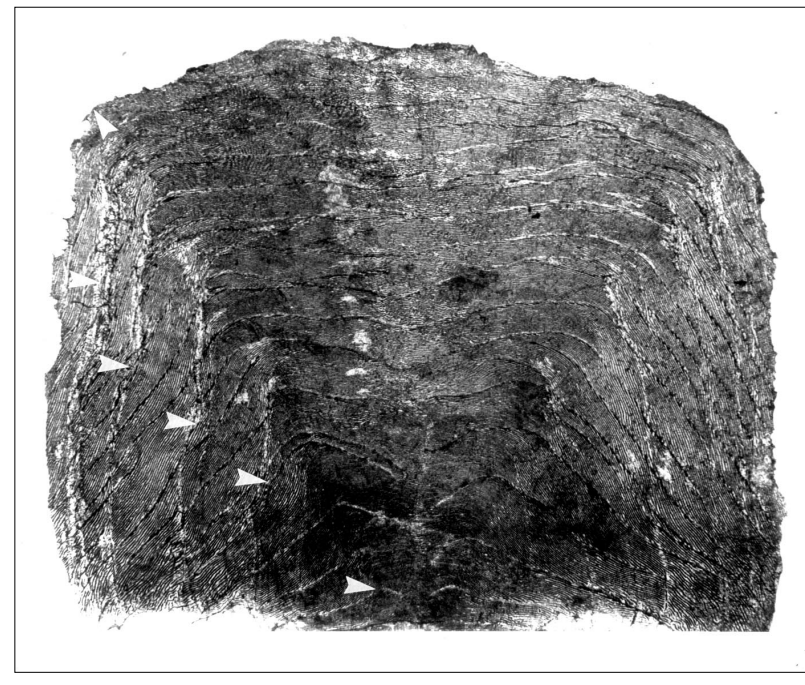

\section{Figure 18}

Grande Alose, Charente, 520, F, $6^{\circ}$ (x10).

Figure 18

Allis shad, Charente, 520, F, $6^{\circ}$ (x10). 


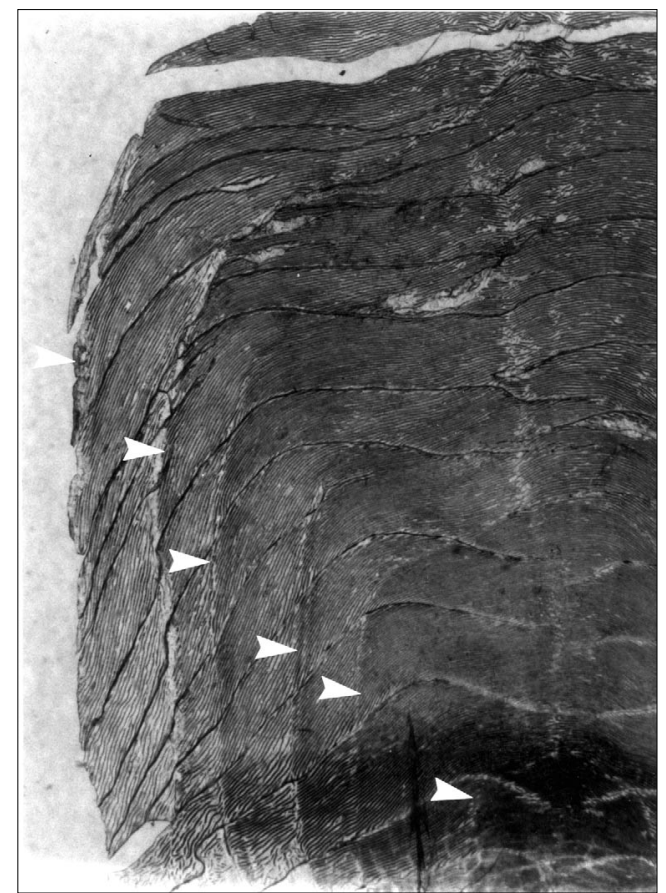

Figure 19

Grande Alose, Gironde, (469), F, $6^{\circ}$ (x20).

Figure 19

Allis shad, Gironde, (469), F, $6^{0}$ (x20).

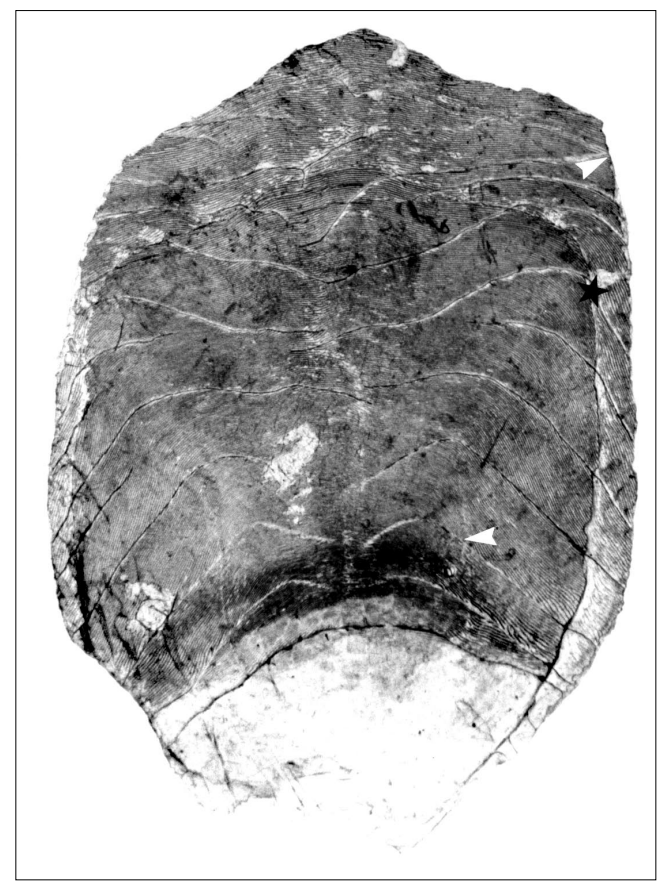

Figure 21

Grande Alose (population enfermée), Zézère, 432, F, 3', (x15).

\section{Figure 21}

Allis shad (landlocked population), Zezere, 432, F, $3^{1}$, (x15).

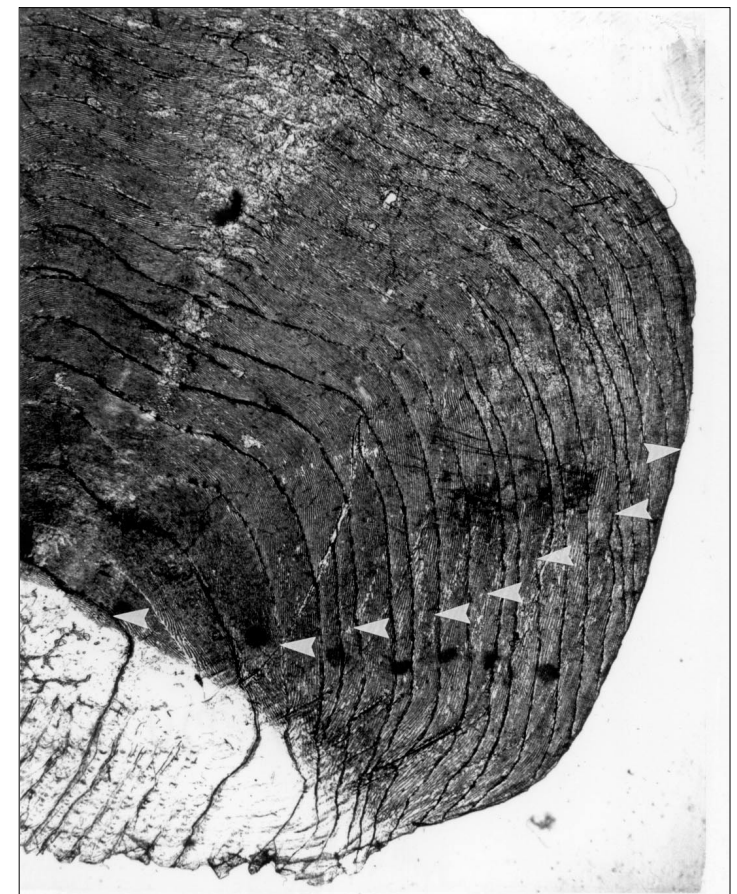

Figure 20

Grande Alose, oued Sebou, 670, F, $8^{0}$.

Figure 20

Allis shad, oued Sebou, 670, F, $8^{\circ}$.

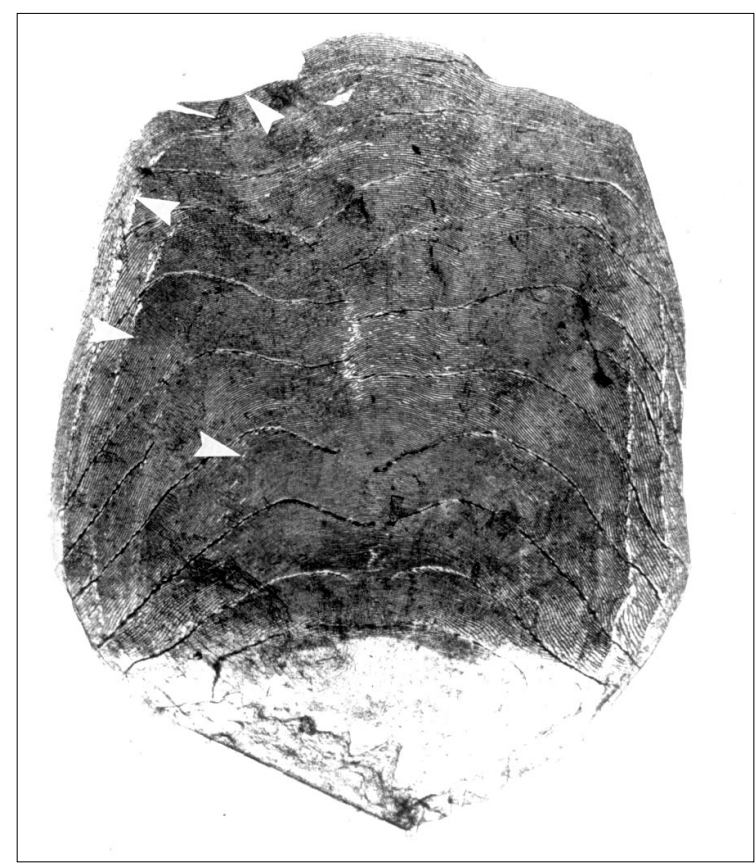

Figure 22

Grande Alose (population enfermée), Zézère, 406, $F, 4^{0},(x 10)$.

Figure 22

Allis shad (landlocked population), Zezere, 406, F, $4^{0}$, (x10). 


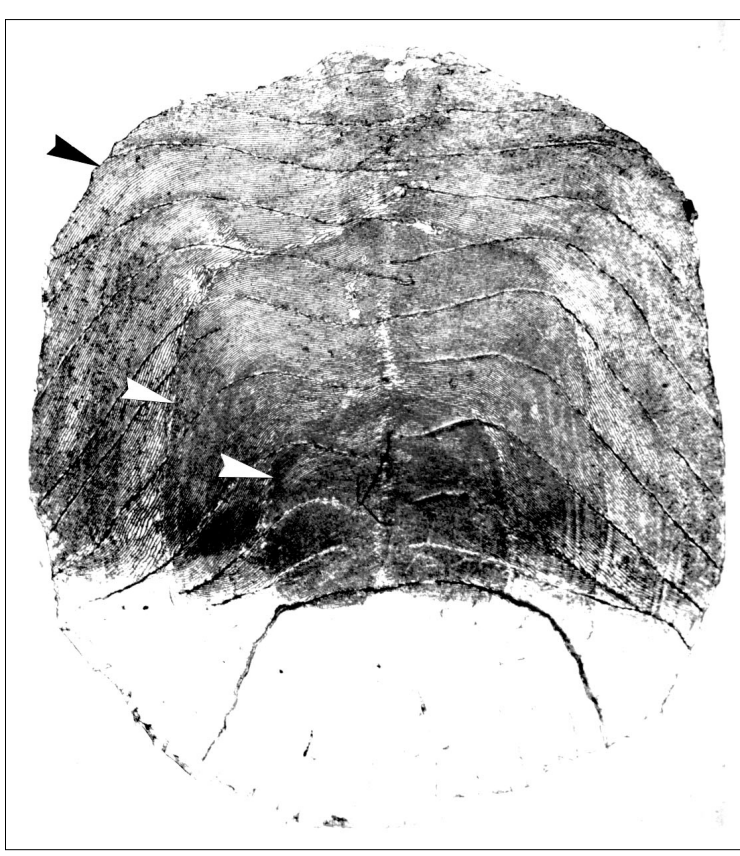

Figure 23

Alose hybride, Loire (Vienne), (390), M, $3^{0}$, (x10).

Figure 23

Hvbrid shad, Loire (Vienne), (390), M, $3^{0}$,

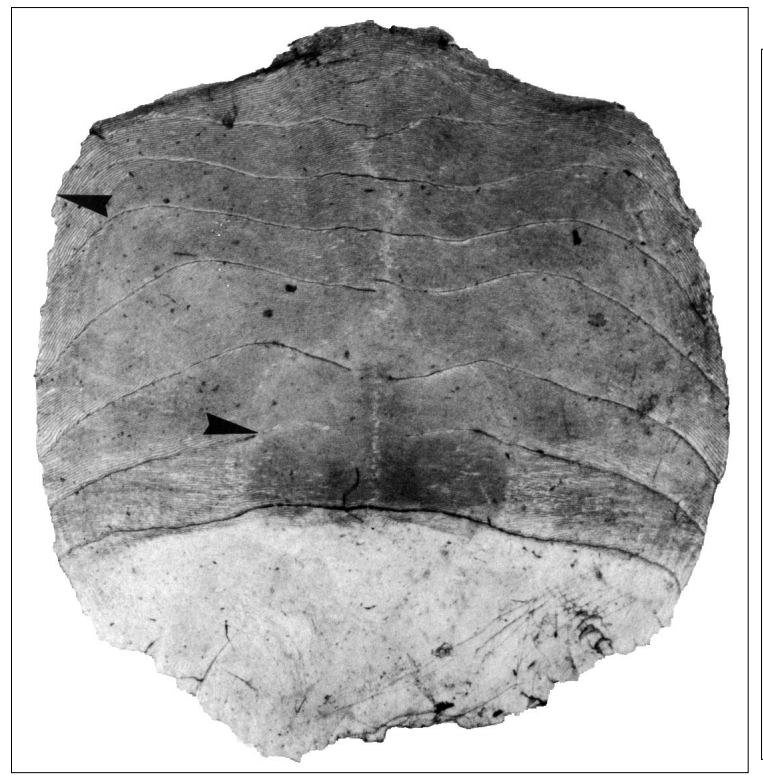

Figure 25

Alose feinte, Tage, $299, \mathrm{M}, \mathbf{2}^{0}$, (x10).

Figure 25

Twaite shad, Tage, $299, \mathrm{M}, \mathbf{2}^{0}$, (x10).

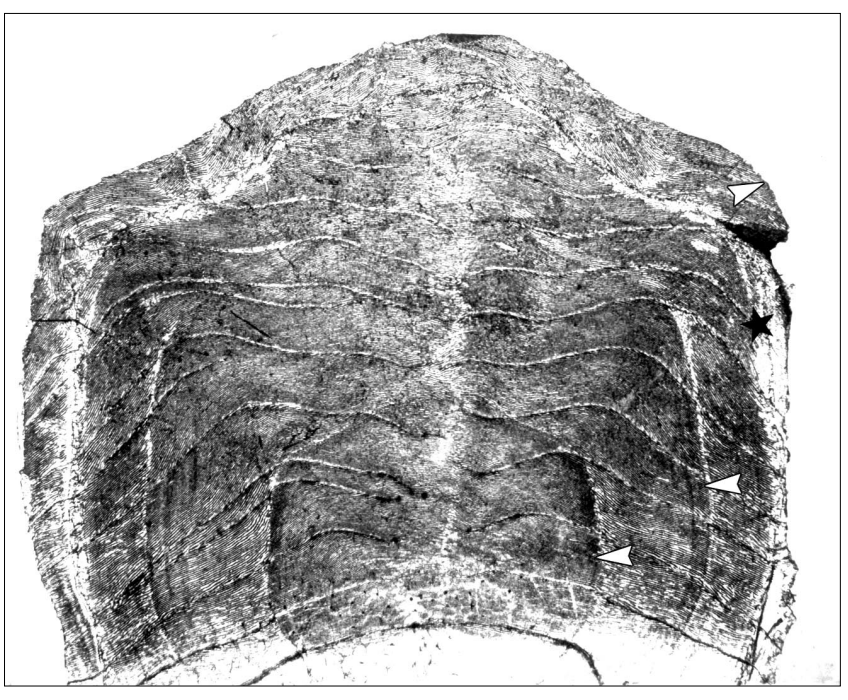

Figure 24

Alose hybride, Loire (Vienne), (375), M, 4', (x10).

Figure 24

Hvbrid shad, Loire, (375), M, 4', (x10).

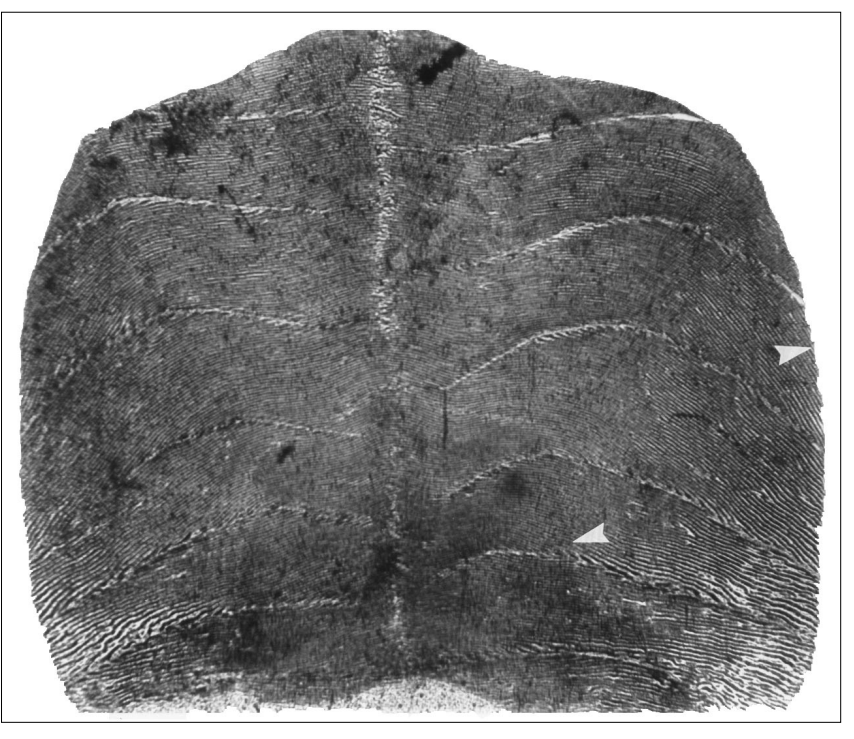

Figure 26

Alose feinte, oued Sebou, 333, M, $2^{\circ},(x 10)$.

Figure 26

Twaite shad, oued Sebou, 333, M, $2^{0}$, (x10). 


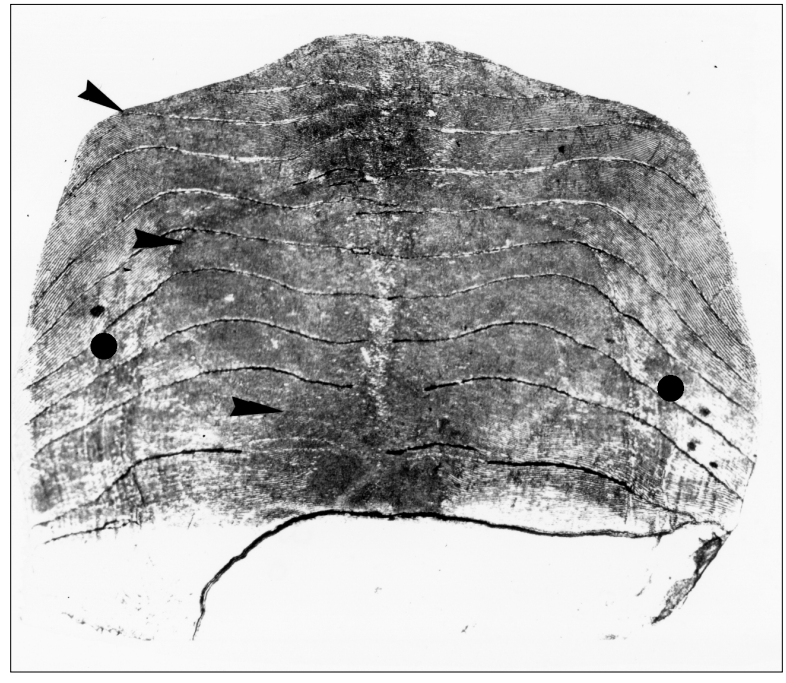

Figure 27

Alose feinte, Severn, (285), M, $3^{0},(x 10)$.

Figure 27

Twaite shad, Severn, (285), M, $3^{0}$, (x10).

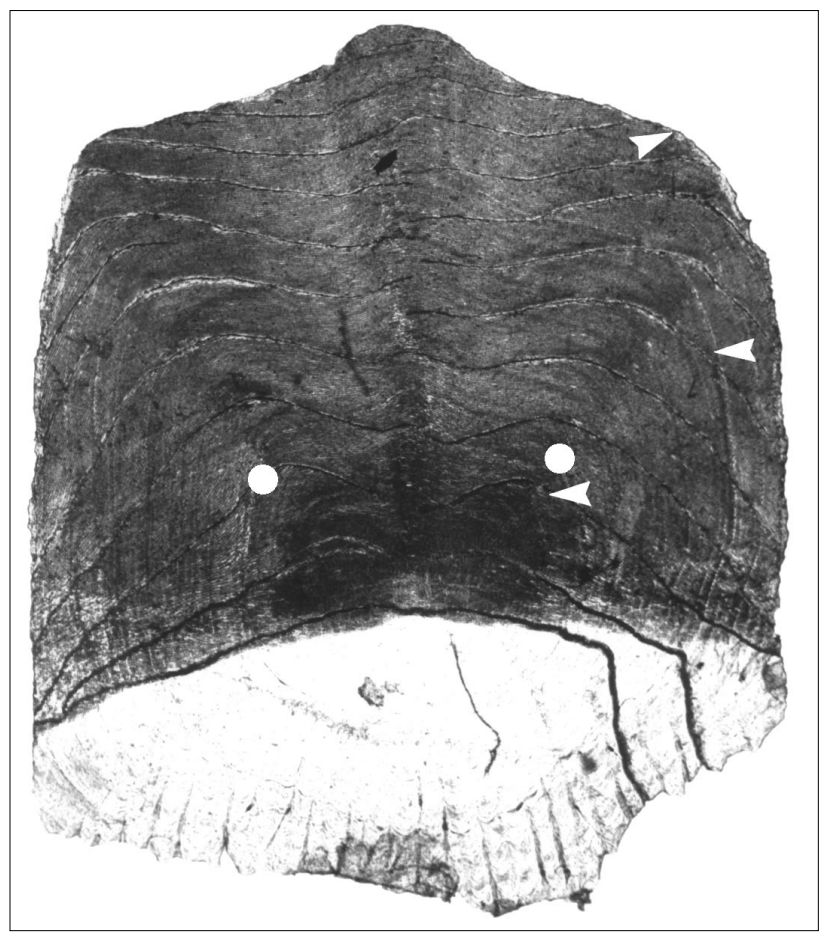

Figure 29

Alose feinte, Lima, $375, \mathrm{~F}, 3^{0}$, (x12).

Figure 29

Twaite shad, Lima, 375, F, $3^{0}$, (x12).

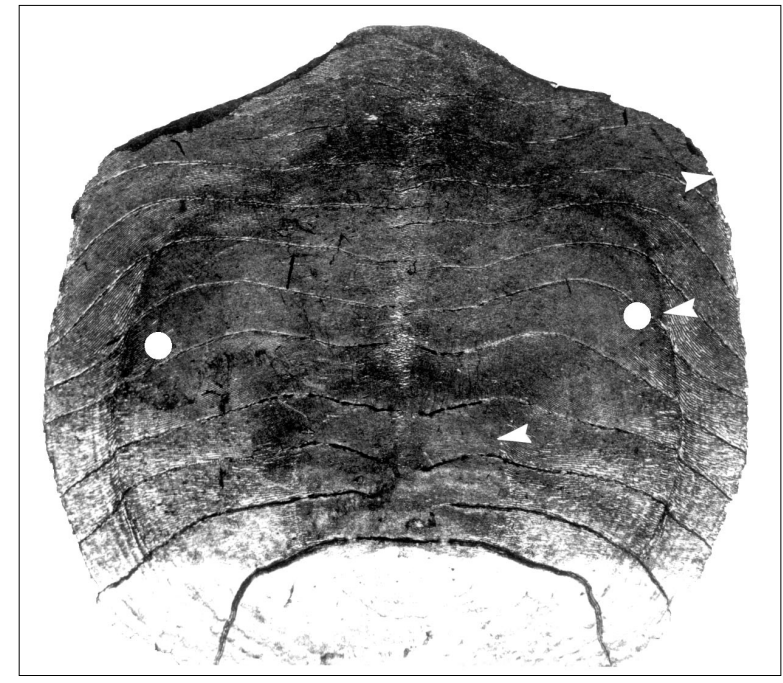

Figure 28

Alose feinte, Loire, (285), M, $3^{0},(\times 10)$.

Figure 28

Twaite shad, Loire, (285), M, $3^{0}$, (x10).

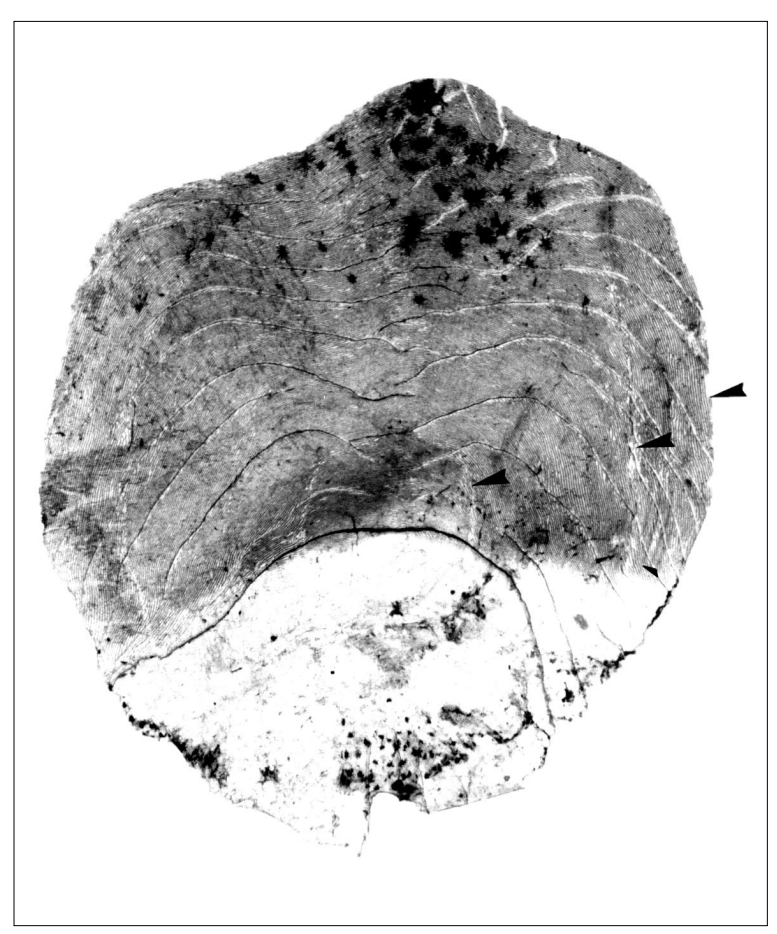

Figure 30

Alose feinte, oued Sebou, 380, F, $3^{0},(x 10)$.

Figure 30

Twaite shad, oued Sebou, 380, F, $3^{0}$, (x10). 


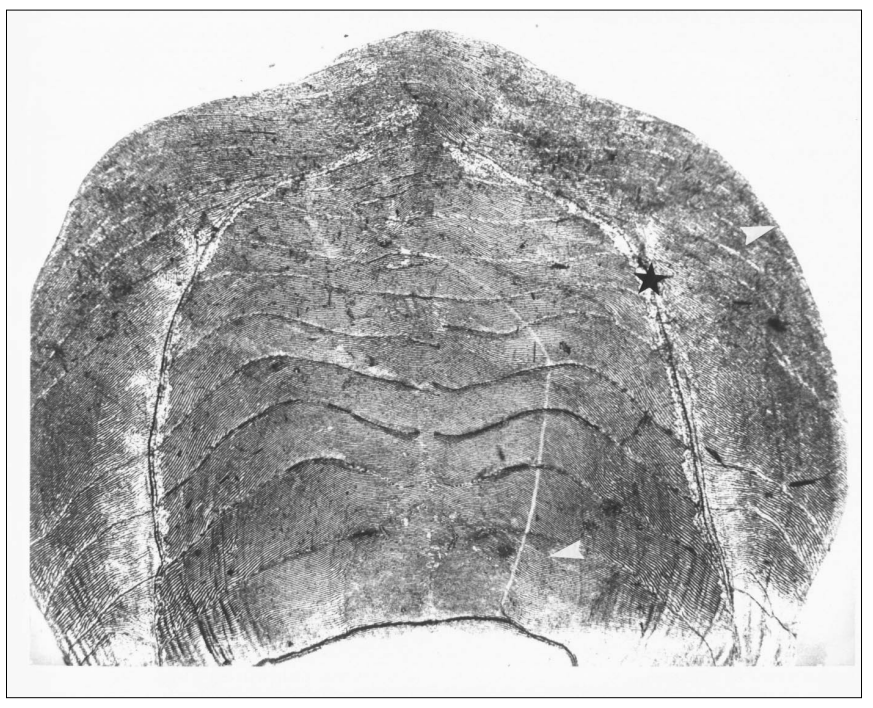

Figure 31

Alose feinte, Loire, (440), F, $3^{1}$, (x10).

Figure 31

Twaite shad, Loire, (440), F, 31, (x10).

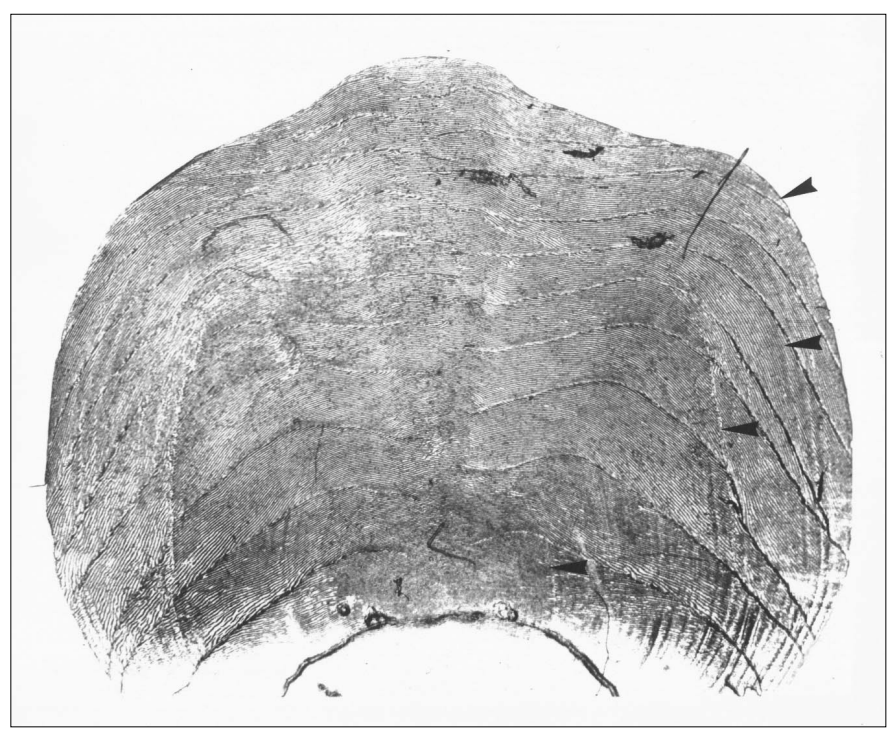

Figure 33

Alose feinte, Rhône, - , M, $4^{0}$, (x10).

Figure 33

Twaite shad, Rhone, - , M, $4^{0}$, (x10).

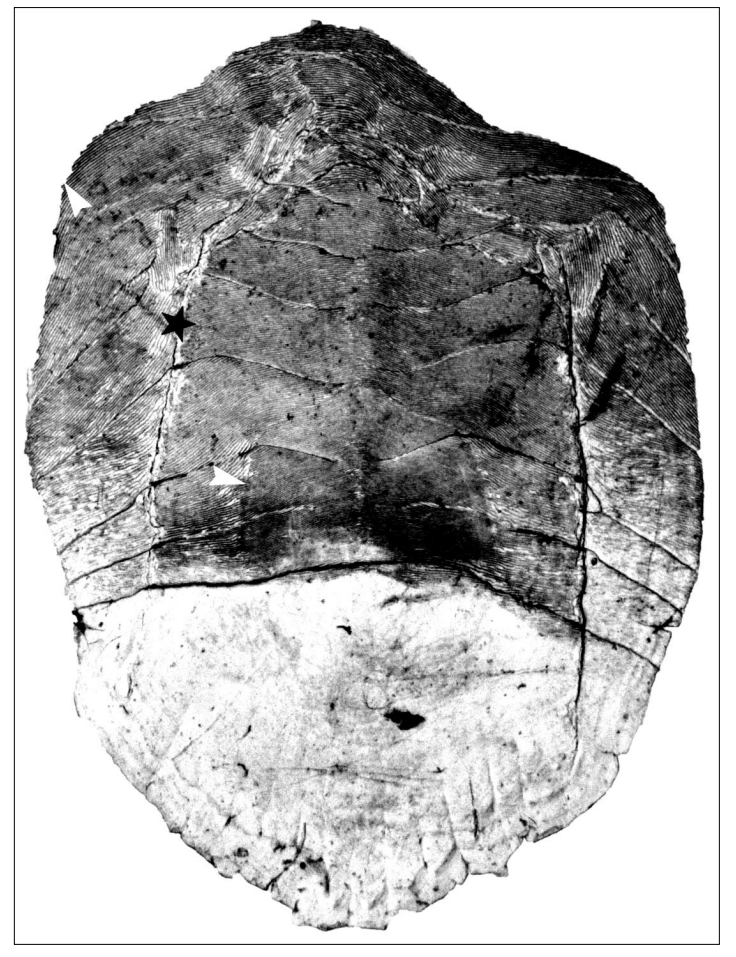

Figure 32

Alose feinte, Tage, 335, M, $3^{1}$, (x15).

Figure 32

Twaite shad, Tage, 335, M, $3^{1}$, (x15).

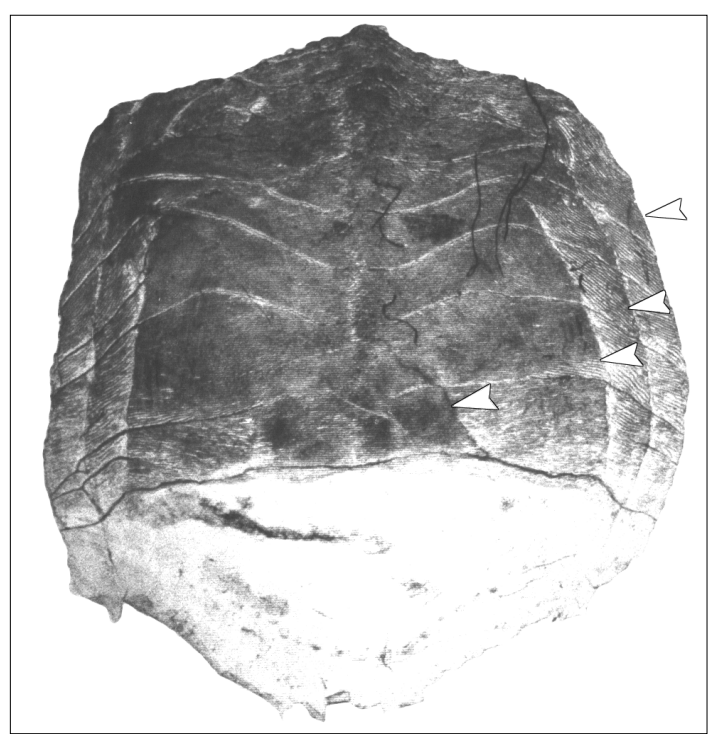

Figure 34

Alose feinte, Tage, $315, \mathrm{M}, 4^{0}$, (x9).

Figure 34

Twaite shad, Tage, $315, M, 4^{0},(x 9)$. 


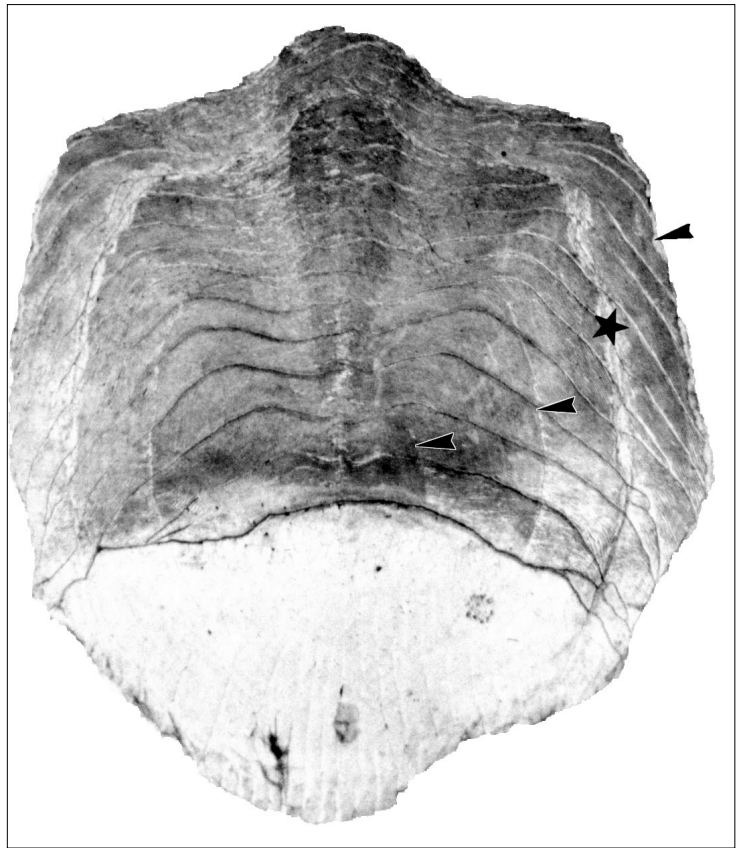

Figure 35

Alose feinte, Guadiana, 430, F, 4 , (x9).

Figure 35

Twaite shad, Guadiana, 430, F, $4^{1}$, (x9).

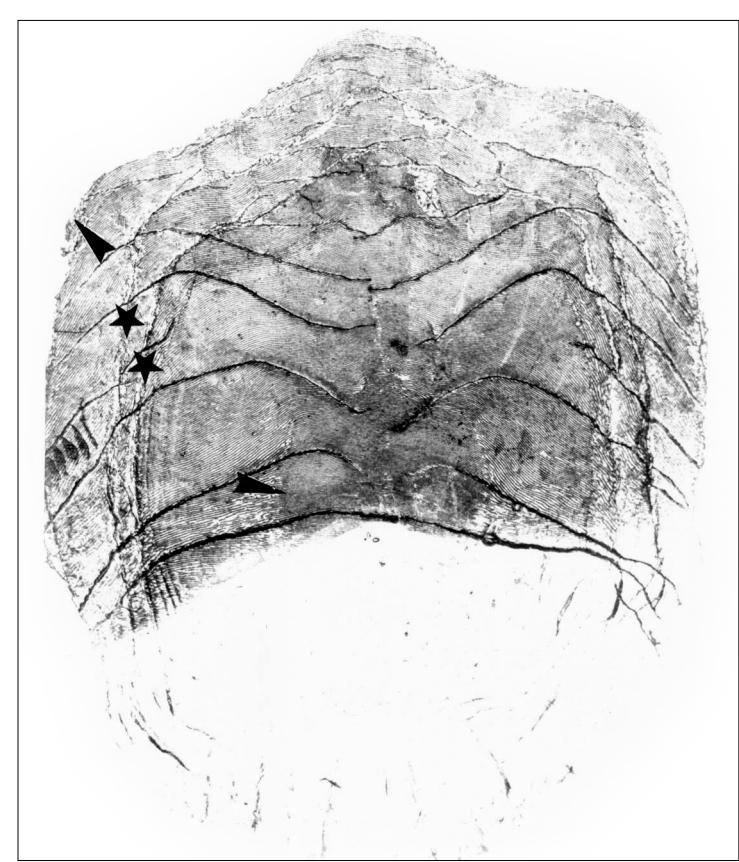

Figure 36

Alose feinte, Tage, 426, F, $4^{2}$, (x10).

Figure 36

Twaite shad, Tage, 426, F, $4^{2},(\times 10)$.

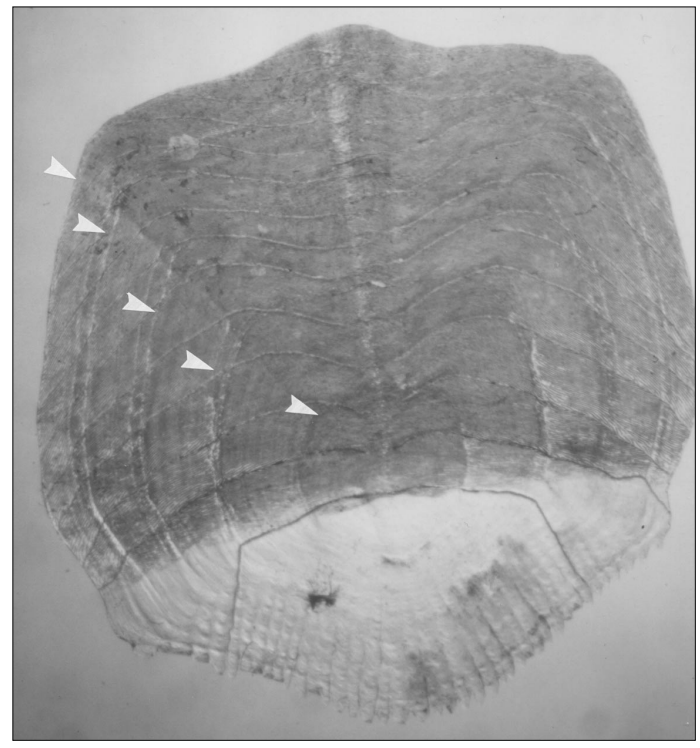

Figure 37

Alose feinte, Severn, (349), F, $5^{0},(x 10)$.

Figure 37

Twaite shad, Severn, (349), F, $5^{0}$ (x10).

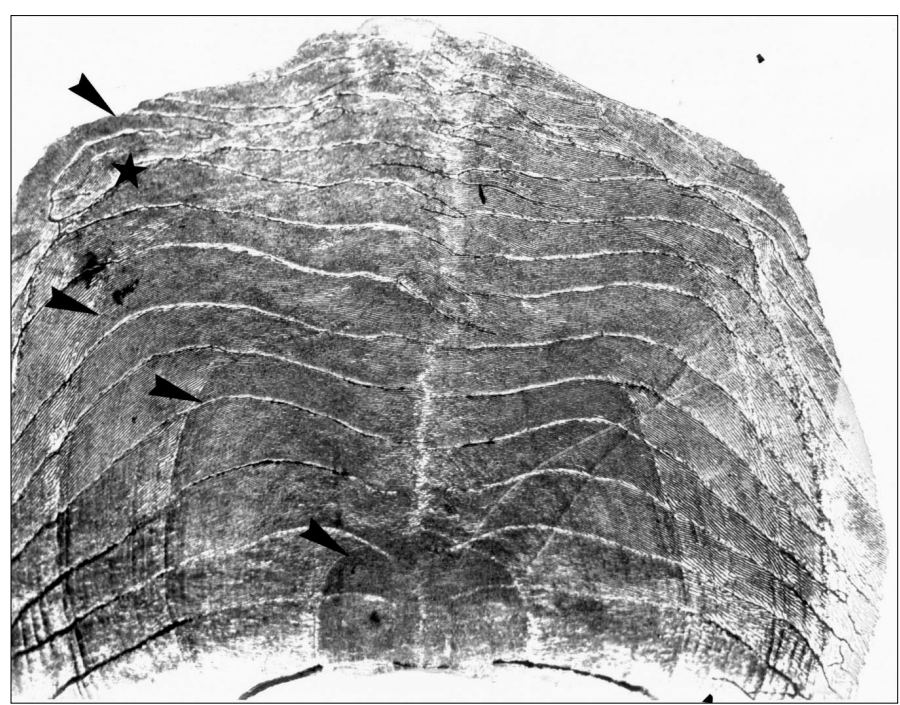

Figure 38

Alose feinte, Severn, (337), F, $5^{1}$, (x10).

Figure 38

Twaite shad, Severn, (337), F, $5^{1}$ (x10). 


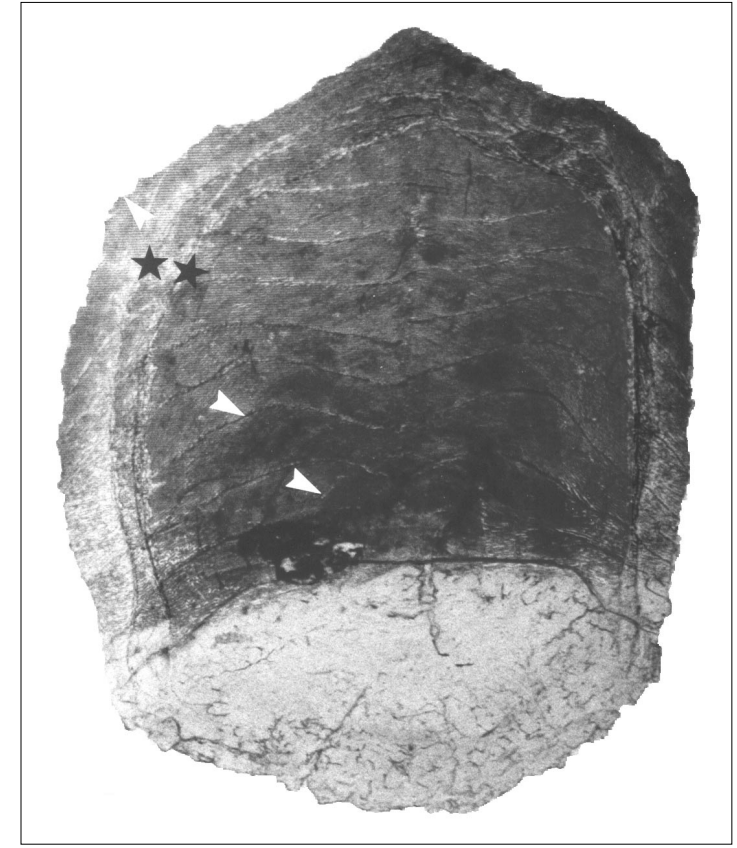

Figure 39

Alose feinte, Tage, 414, F, $5^{2}$ (x11).

Figure 39

Twaite shad, Tage, 414, F, $5^{2}$ (x11).

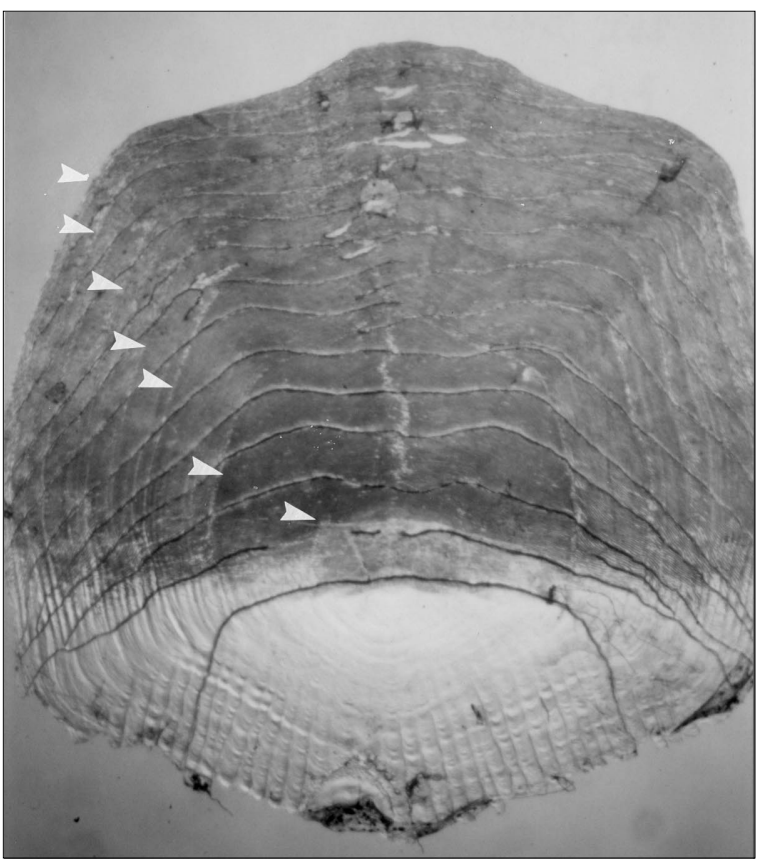

Figure 41

Alose feinte, Severn, (362), F, $7^{0}$ (x10).

Figure 41

Twaite shad, Severn, (362), F, $7^{0}$ (x10).

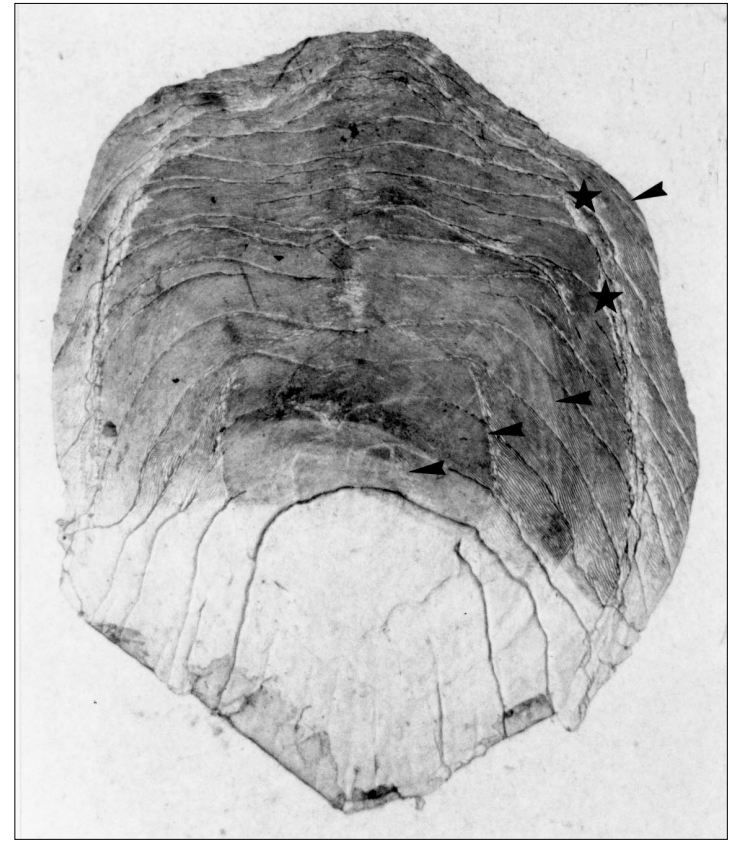

Figure 40

Alose feinte, Dordogne, 459, F, $6^{2}$ (x11).

\section{Figure 40}

Twaite shad, Dordogne, 459, F, $6^{2}$ (x11).

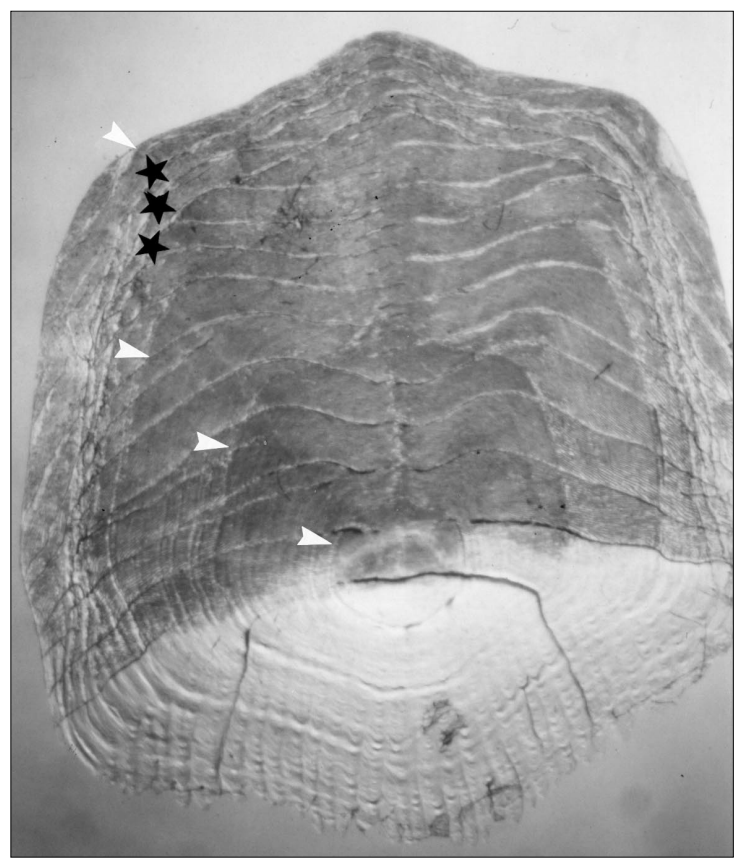

Figure 42

Alose feinte, Severn, (366), F, $7^{3}$ (x10).

Figure 42

Twaite shad, Severn, (366), F, $7^{3}$ (x10). 


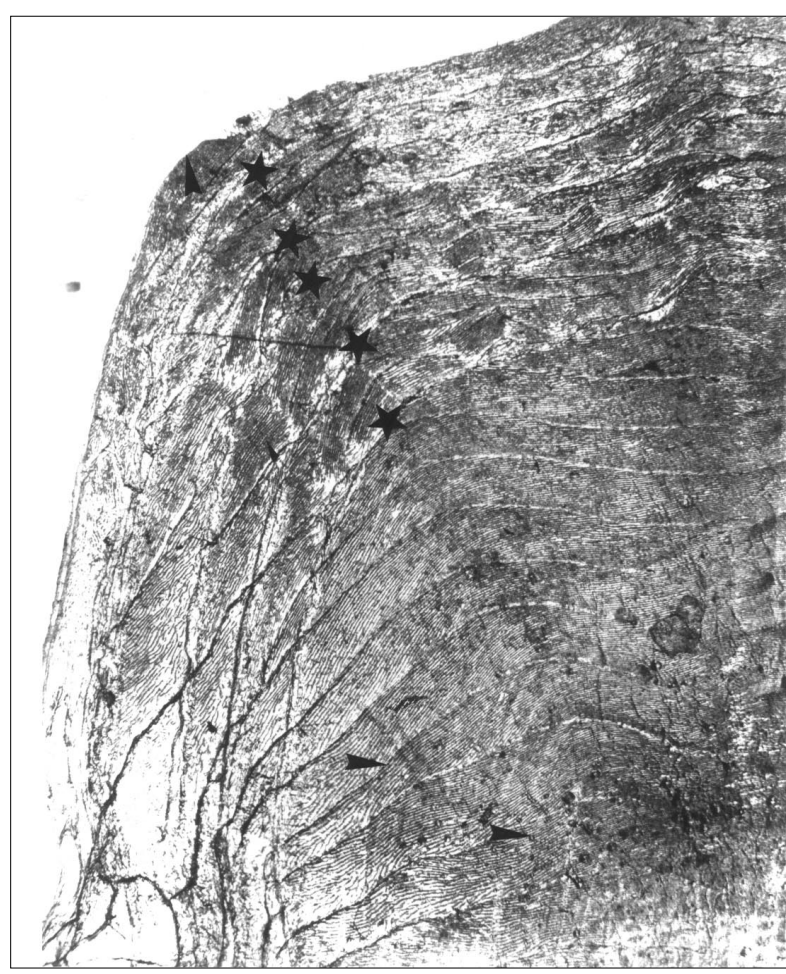

Figure 43

Alose feinte, Rhône, 577 , F, $8^{5}$ (x10).

Figure 43

Twaite shad, Rhône, 577 , F, $8^{5}$ (x10).

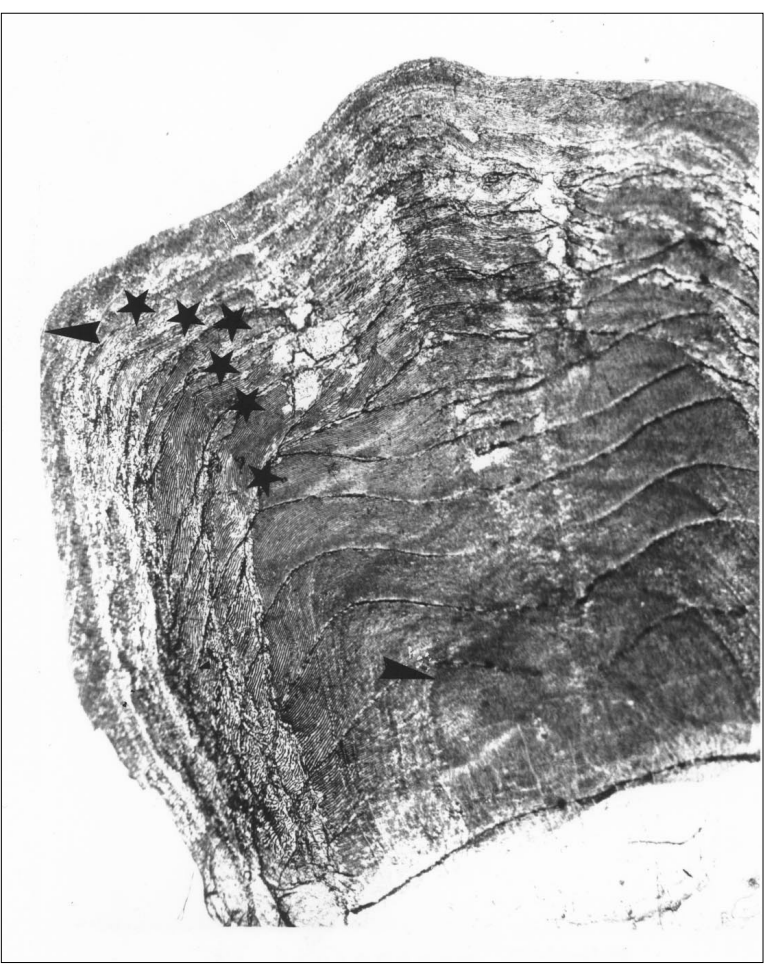

Figure 44

Alose feinte, Severn, (352), M, $8^{6}$ (x10).

Figure 44

Twaite shad, Severn, (352), M, $8^{6}$ (x10).

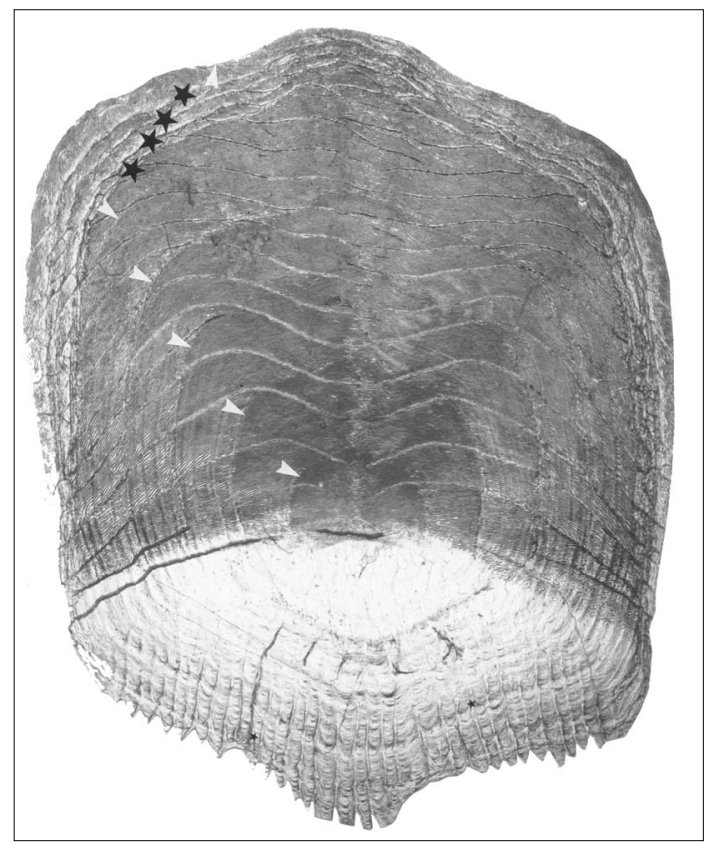

Figure 45

Alose feinte, Severn, (398), F, $10^{4}$ (x10).

Figure 45

Twaite shad, Severn, (398), F, $10^{4}$ (x10). 


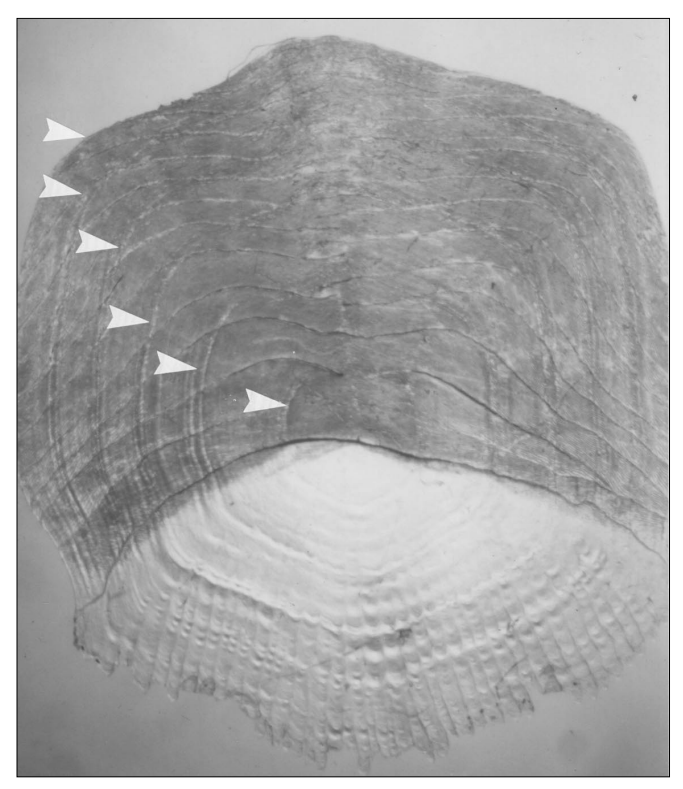

Figure 46

Faible dédoublement de l'anneau hivernal sur une écaille d'Alose feinte (Severn, 6 ans) $(>$ : anneau hivernal) (x10).

Figure 46

Very light structure of double ring on a scale of Twaite shad (Severn, 6 years) ( $>$ : winter ring) (x10).

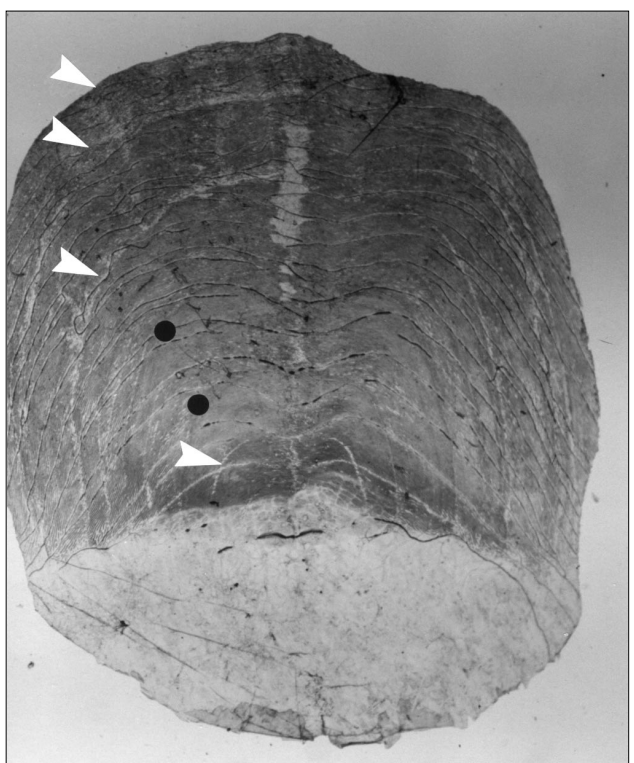

Figure 48

Anneau surnuméraire ( $(\bullet)$ après le premier annulus sur une écaille de grande Alose (Garonne, 4 ans) (> : anneau hivernal) (x6).

\section{Figure 48}

Supernumary ring (๑) after the first annulus on a scale of Allis shad (Garonne, 4 years) $(>$ : winter ring) $(x 6)$.

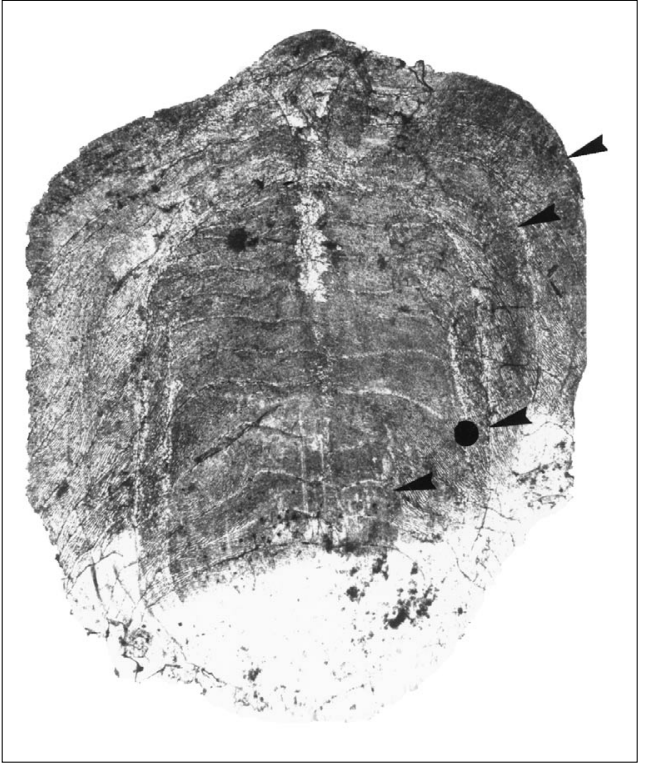

Figure 47

Dédoublement important de l'anneau hivernal sur une écaille de grande Alose (Loire, probablement 4 ans) ( $>$ : anneau hivernal, $:$ anneau surnuméraire) (x10).

Figure 47

Large structure of double ring on a scale of Allis shad (Loire, probably 4 years) ( $>$ : winter ring, 0 : supernumary ring) (x10).

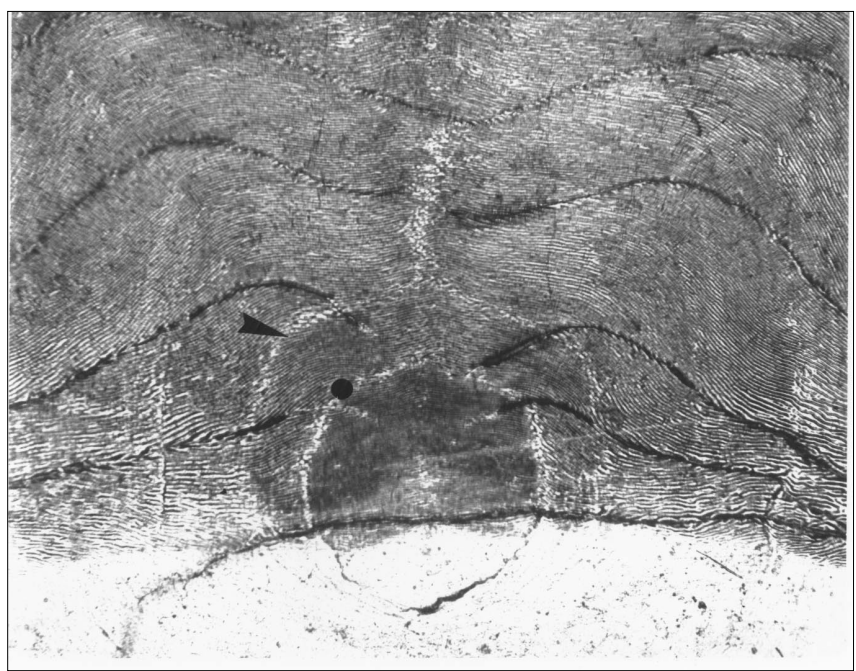

Figure 49

Marque dite de crue (๑) observée prés du centre de l'écaille chez une alose feinte (oued Sebou) ( $>$ : anneau hivernal) (x30).

Figure 49

Mark termed spate mark (๑) observed very close to the scale' centre in a juvenile Twaite shad (oued Sebou) ( $>$ : 
A

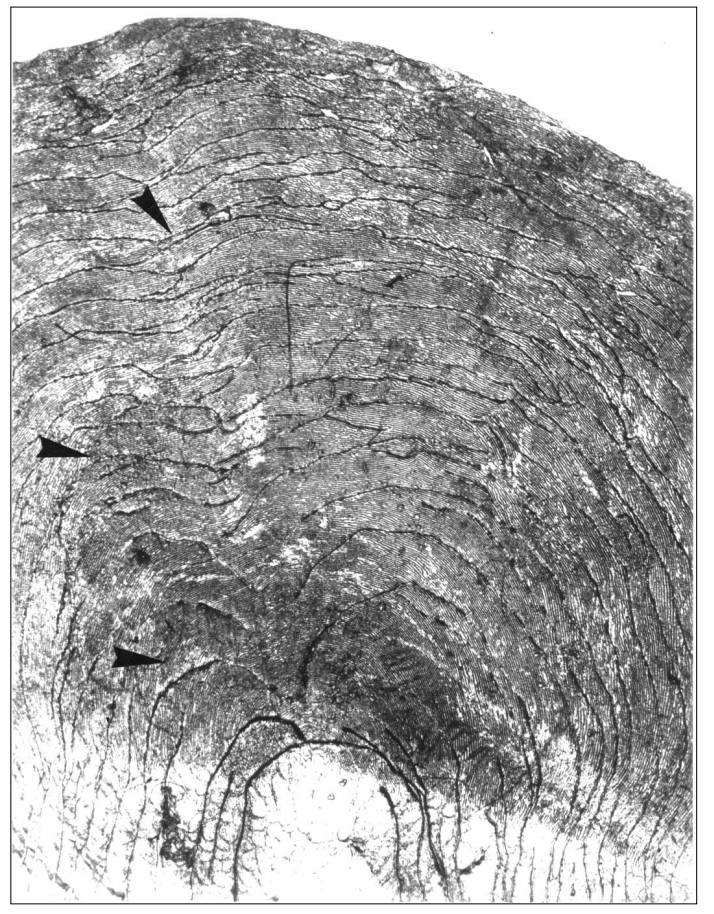

B

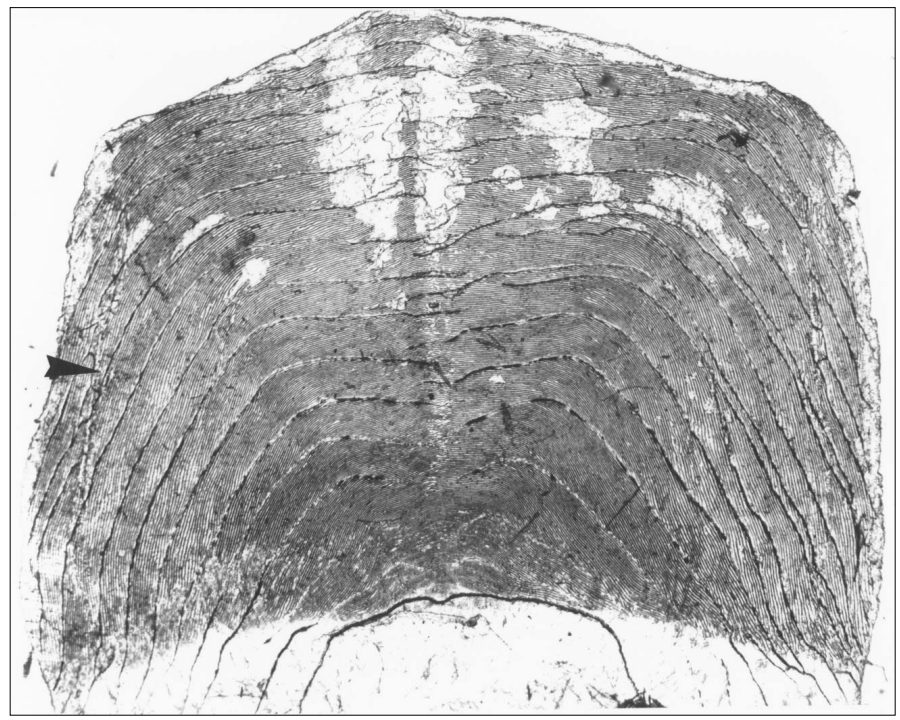

C

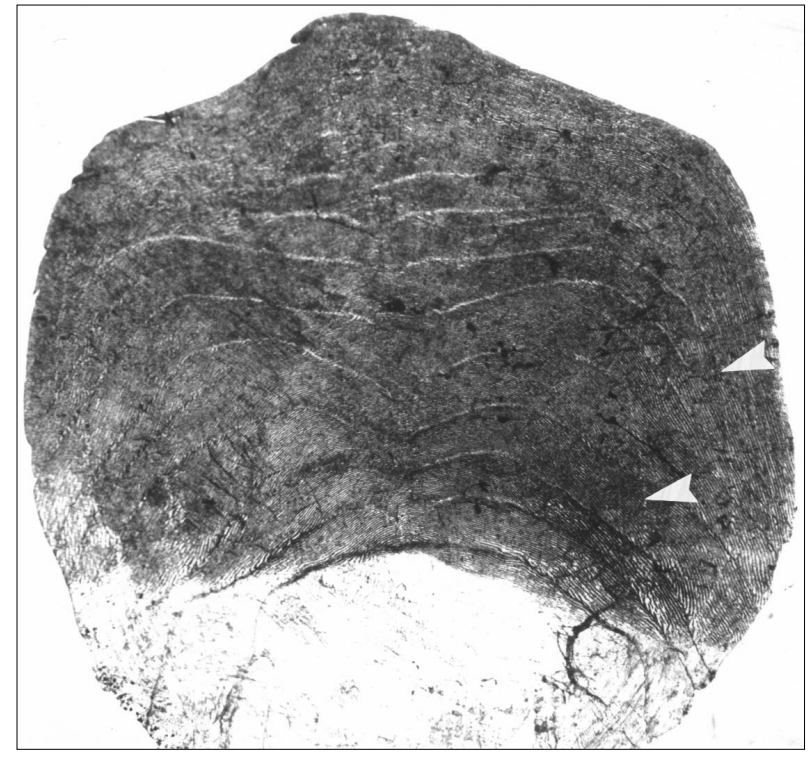

\section{Figure 50}

Absence ou présence d'anneaux hivernaux très faiblement marqués $(>$ : anneau hivernal marqué ou possible) : Grande Alose : $(A, x 10)$ Loire, 3,7 kg, gros poisson, possible 7 ans ; (B, x10) oued Sebou, $645 \mathrm{~mm}$ longueur totale, gros poisson, âge non estimé ; Alose feinte : (C, x10) Rhône, $470 \mathrm{~mm}$ longueur totale, âge non estimé.

\section{Figure $\mathbf{5 0}$}

Absence of annuli or very slightly marked annuli ( $>$ : winter ring marked or possible): Allis shad: $(A, x 10)$ Loire, 3,7 kg, large fish, possible 7 years; $(B, x 10)$ oued Sebou, $645 \mathrm{~mm}$ total length, large fish, non estimated age; Twaite shad: (C, x10) Rhône, $470 \mathrm{~mm}$ total length, non estimated age. 
D

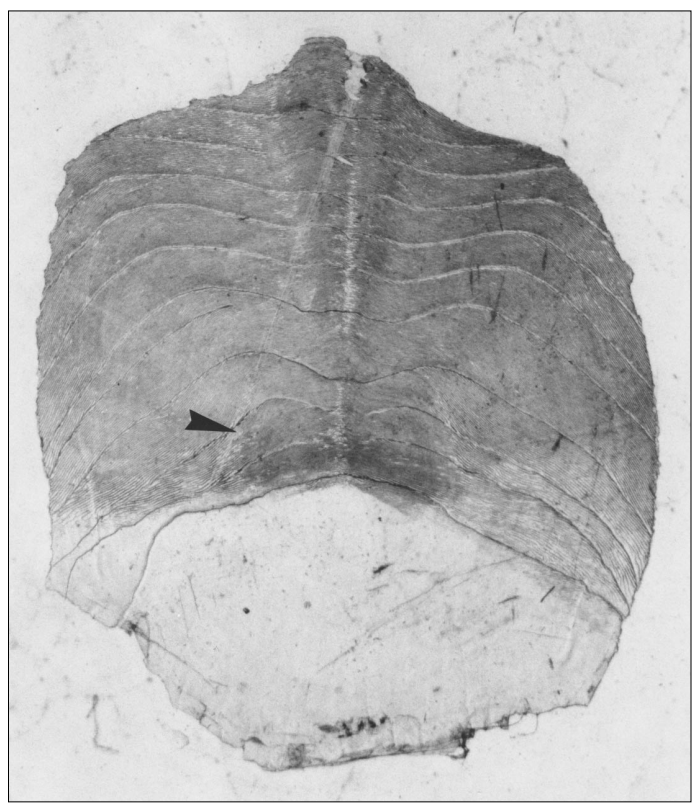

Figure 50

Absence ou présence d'anneaux hivernaux très faiblement marqués $(>$ : anneau hivernal marqué ou possible) : Alose feinte : (D, x11) Tage, $378 \mathrm{~mm}$ longueur totale, âge non estimé ; $(E, x 10)$ oued Sebou, $340 \mathrm{~mm}$ longueur totale, âge non estimé (possible 3 ans).

\section{Figure 50}

Absence of annuli or very slightly marked annuli ( $>$ : winter ring marked or possible): Twaite shad: (D, x11) Tage, $378 \mathrm{~mm}$ total length, non estimated age; (E, x10) oued Sebou, $340 \mathrm{~mm}$ total length, non estimated age (possible 3 years).

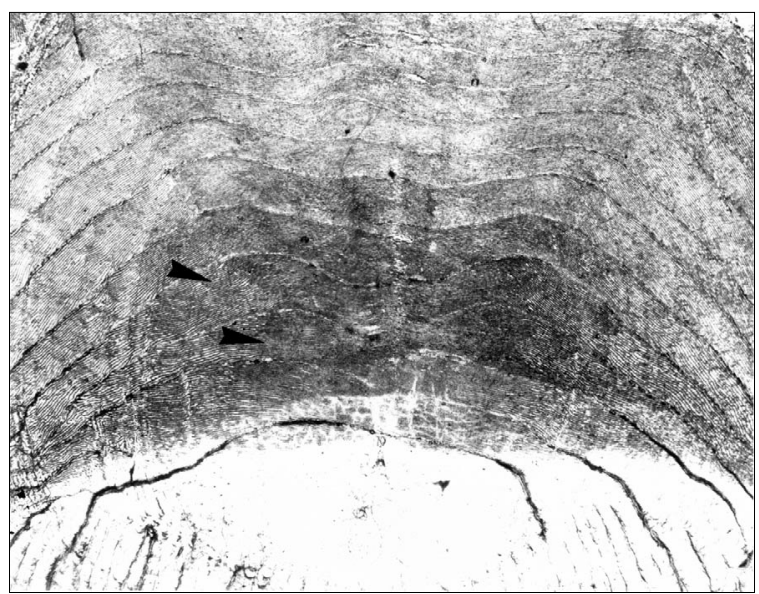

Figure 51

Localisation difficile du premier annulus $(>)$ (Alose feinte, Rhône) (x20).

Figure 51

Difficulty for localization of the first annulus (>) (Twaite shad, Rhône) (x20).

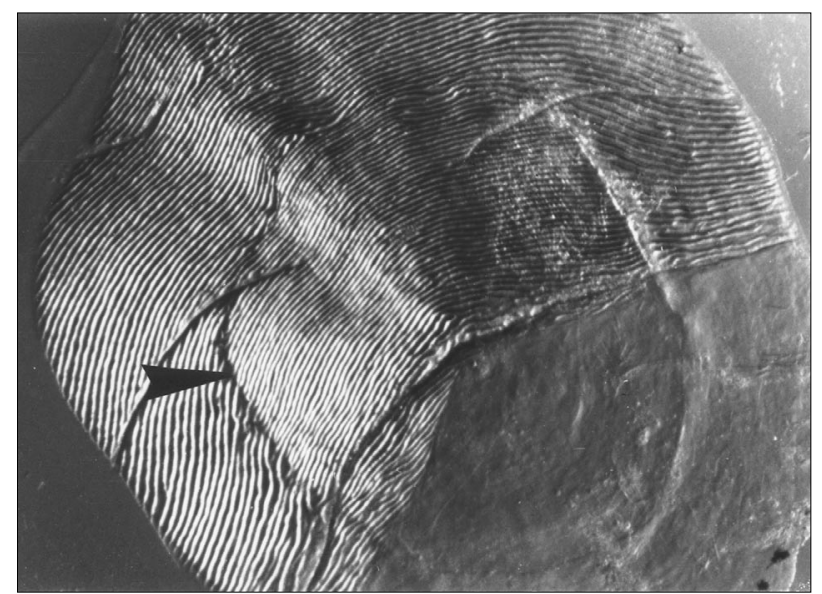

Figure 52

Position du premier annulus $(>)$ sur une écaille de juvénile d'alose feinte (longueur totale : $117 \mathrm{~mm}$ ) capturé en juin en Gironde (x40).

\section{Figure 52}

Position of the first annulus $(>)$ on a scale of juvenile Twaite shad (total length: $117 \mathrm{~mm}$ ) caught in june in the River Gironde (x40). 
A

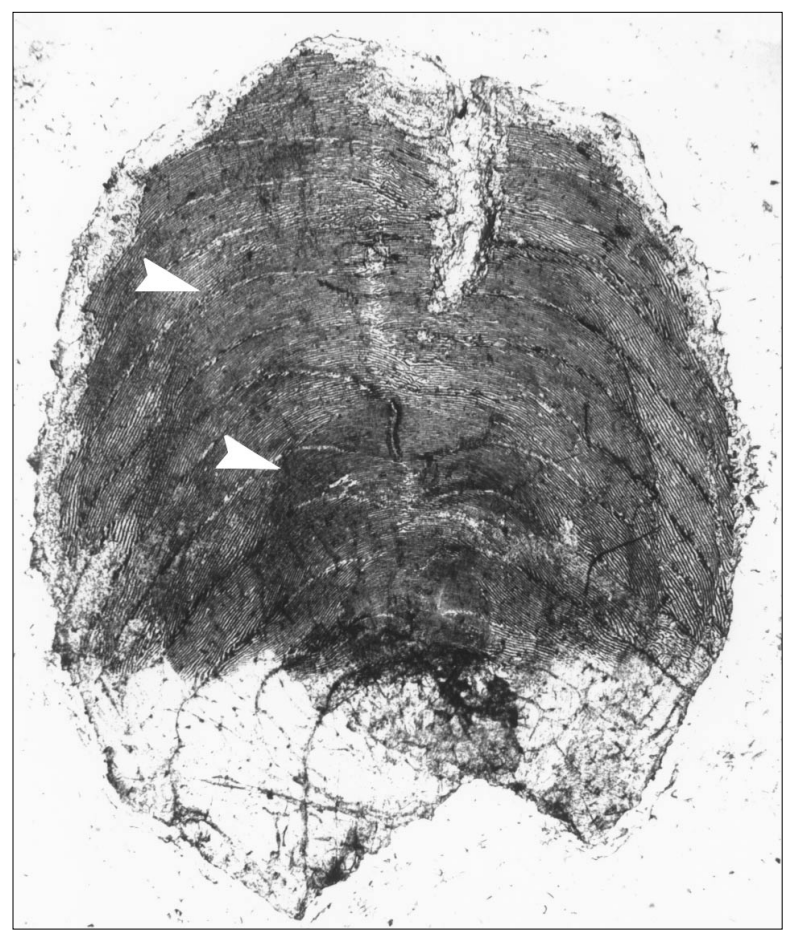

B

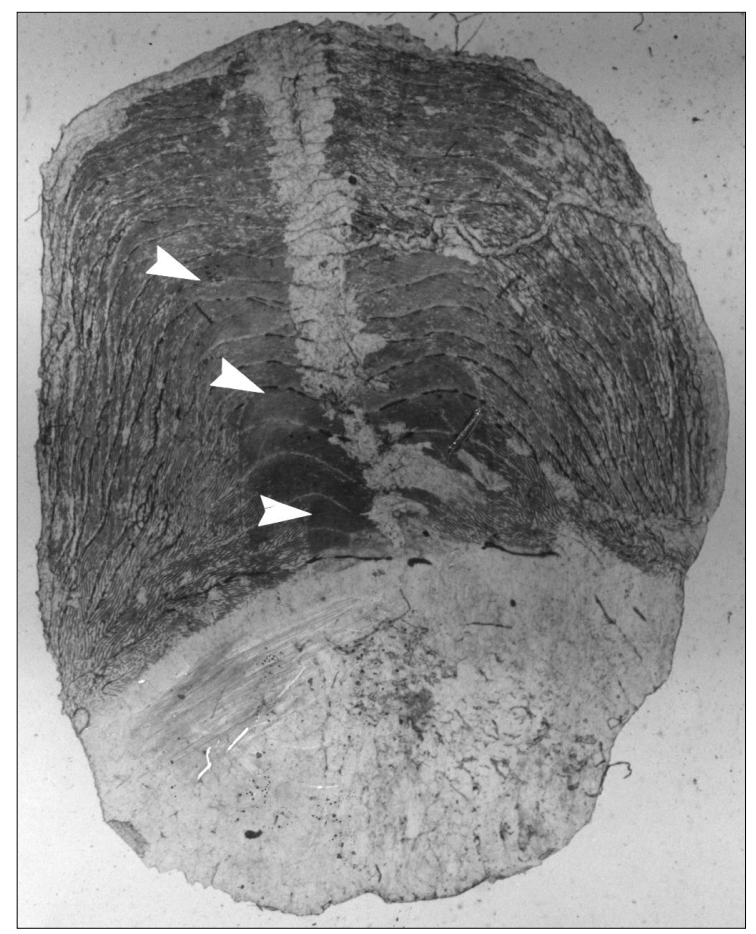

Figure 53

Forte érosion en bordure d'écaille chez la grande Alose : (A, x10) Charente, âge possible 4 ans ; $(B, x 6)$ Garonne, âge possible 5 ans ( $>$ : anneau hivernal visible).

\section{Figure 53}

Strong erosion on scale edge in Allis shad: (A, x10) Charente, possible age 4 years ; $(B, x 6)$ Garonne, possible age 5 years ( $>$ : visible winter ring). 


\section{A}
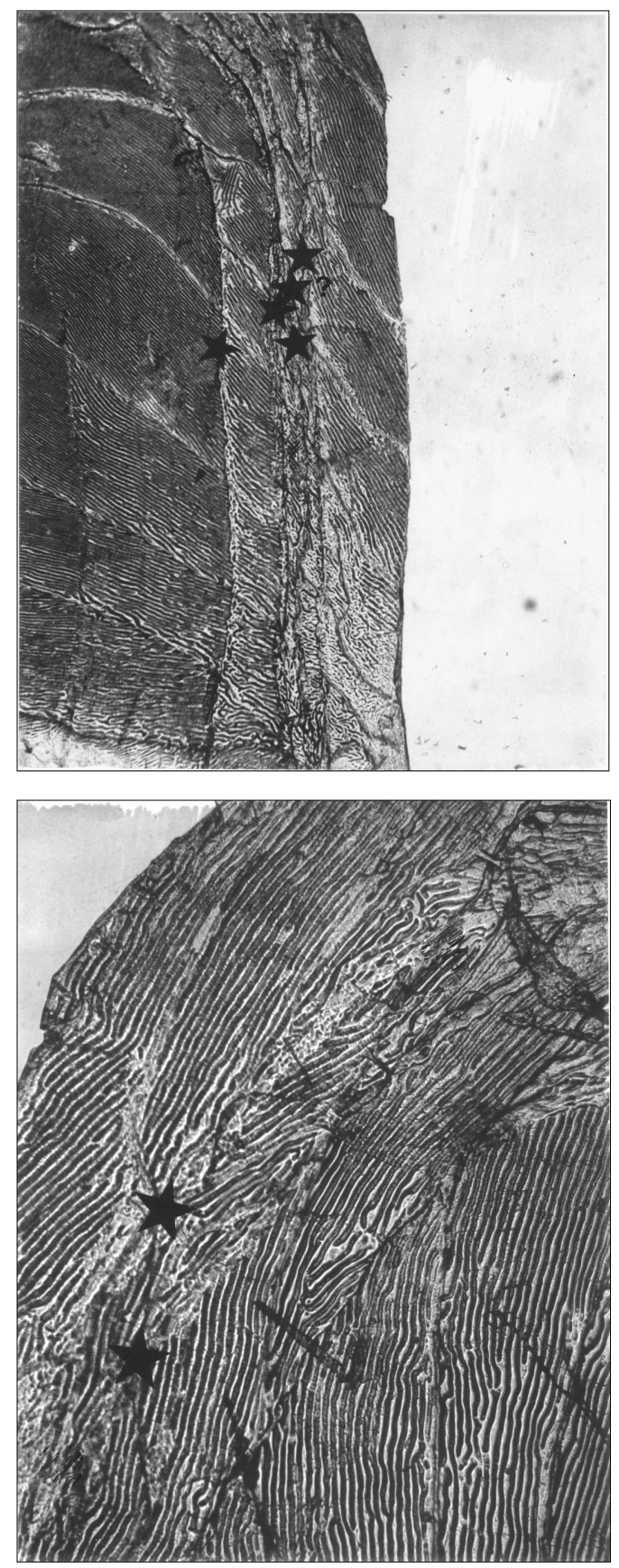

B

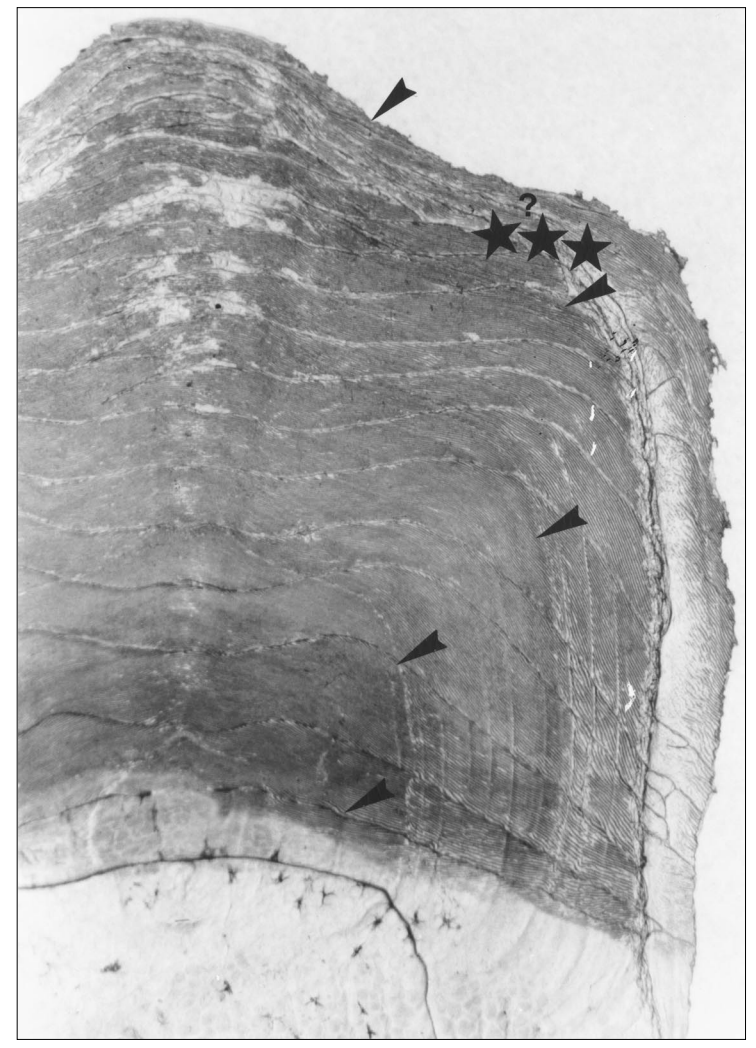

C

\section{Figure 54}

Surimposition de marques de reproductions $(*)$ sur une écaille d'Alose feinte : $(A, \mathbf{x 2 0})$ Severn, 4 ou 5 marques de reproduction, âge possible $8^{5}$ ans ; (B, x15) 2 ou 3 marques de reproductions, âge possible $7^{2}$ ou $8^{3}$ ans ; (C, X50) Rhône, 2 marques de reproduction ( $>$ : anneau hivernal).

\section{Figure 54}

Imposition of spawning marks ( $*$ ) on a scale of Twaite shad: (A, x20) Severn, 4 or 5 spawning marks, possible age $8^{5}$ years $(B, x 15)$ Severn, 2 or 3 spawnings marks, possible age $7^{2}$ or $8^{3}$ years; (C, x50) Rhône, 2 spawning marks ( $>$ : winter ring). 


\section{BIBLIOGRAPHIE}

ALEXANDRINO P.J., 1996. Estudo de populaçoes de Sável (Alosa alosa L.) e Savelha (Alosa fallax Lacépède). Análise de diferenciaçao interspecífica, subestruturaçao e hibridaçao. Tese de doutoramento, Universidade do Porto, $185 \mathrm{p}$.

APRAHAMIAN M.W., 1982. Aspects of the biology of the twaite shad, Alosa fallax fallax Lacépède, in the rivers Severn et Wye. Ph.D thesis, University of Liverpool.

BAGLINIĖRE J.L., 1985. La détermination de l'âge par scalimétrie chez le saumon atlantique dans son aire de répartition méridionale : utilisation pratique et difficultés de la méthode. Bull. Fr. Pêche Piscic., 298, 69-105.

BAGLINIĖRE J.L., 2000. Le genre Alosa sp. In: Les aloses (Alosa alosa et Alosa fallax spp.) : Ecobiologie et variabilité des populations. J.L. BAGLINIĖRE et P. ELIE (Eds), INRA-CEMAGREF, Paris, 3-30.

BAGLINIĖRE J.L., CASTANET J., CONAND F., MEUNIER F.J., 1992. Terminologie en sclérochronologie chez les vertébrés. In: Tissus durs et âge individuel des vertébrés. J.L. BAGLINIĖRE, J. CASTANET, F. CONAND, F.J. MEUNIER (Eds), ORSTOM-INRA Paris, 443-447.

BAGLINIĖRE J.L., LE LOUARN H., 1987. Caractéristiques scalimétriques des principales espèces de poisson d'eau douce en France. Bull. Fr. Pêche Piscic., 306, 1-39.

BEAMISH R.J., MAC FARLANE G.A., 1983.-The forgotten requirement for age validation in fisheries biology. Trans. Amer. Fish. Soc., 112, 735-743.

BERG A., 1966. L'accrescimento annuale e stagionale dell' agone. Mem. Ist. Idrobiol., 20, 41-83.

BURDAK V.D., 1986. Morphologie fonctionnelle du tégument écailleux des poissons. Cybium, 10 (suppl.), $147 \mathrm{p}$.

CASSOU-LEINS F., CASSOU-LEINS J.J., 1981. Recherches sur la biologie et l'halieutique des migrateurs de la Garonne et principalement de l'Alose, Alosa alosa L. Thèse $3^{\text {èm }}$ cycle, Institut National Polytechnique, Toulouse, $382 \mathrm{p}$.

DAUTREY R., LARTIGUE P., 1983. Recherches sur la migration des aloses (Alosa alosa) et des truites de mer (Salmo trutta) en Garonne (Site de Golfech). Thèse $3^{\text {èm }}$ cycle, Institut National Polytechnique de Toulouse, $212 \mathrm{p}$.

DOUCHEMENT C., 1981. Les aloses des fleuves français, Alosa fallax Lacépède 1803 et Alosa alosa Linné 1758. Biométrie, Ecobiologie, Autonomie des populations. Thèse doctorat $3^{\text {ème }}$ cycle, Université des Sciences et Techniques du Languedoc, Montpellier, $377 \mathrm{p}$.

EIRAS J.C., 1981. Contribuçao para o conhecimento da biologia de Alosa alosa L. Estudo de algumas modificaçoes somaticas, fisiologicas ebioquimicas durante a migraçao dorio Douro.Tese de doutoramento, Universidade do Porto.

ELLIOTT J.M., CHAMBERS S., 1996. A Guide to the Interpertation of Sea Trout scales. NRA, Inst. Freshwat. Ecol., R\&D Rep., 22, 54 p.

FRANCIS R.I.C.C., 1990. Back-calculation of fish length : a critical review. J. Fish. Biol., 36, 883-902.

HASS H., 1965. Untersuchungen über den Laichfischbestand der Elbfinte, Alosa fallax (Lacépède 1803). Archiv für Fischereiwissenschaft, 16, 150-168.

HOESTLANDT H., 1958. Reproduction de l'Alose Atlantique (Alosa alosa Linné) et transfert au bassin méditerranéen. Verhandl., Internat. Verein. Limnol., 13, 736-742.

LE CORRE M., LINHARES D., CASTRO F., ALEXANDRINO P., SABATIÉ R., BAGLINIÈRE J.L., 1998. Premiers éléments de caractérisation génétique de l'Alose du Rhône (Alosa fallax rhodanensis, Roule 1924). Bull. Fr. Pêche Piscic., 350-351, 635-645.

LE CORRE M., SABATIÉ M.R., BAGLINIÈRE J.L., 2000. Caractérisation démographique de populations d'Alosa fallax rhodanensis (Roule 1924) (Clupeidae) de la Méditerranée française. Cybium, 24 (3) suppl., 119-128.

LE CORRE M., SABATIÉ R., BAGLINIĖRE J.L., MENELLA J.Y., PONT D., 1997. Données récentes sur les caractéristiques morphologiques et biologiques de la population 
d'Alose feinte du Rhône (Alosa fallax rhodanensis, Roule 1924). Bull. Fr. Pêche Piscic., 346, 527-545.

MENNESSON-BOISNEAU C., APRAHAMIAN M.W., SABATIÉ M.R, CASSOU-LEINS J.J., 2000. Caractéristiques des adultes. In: Les aloses (Alosa alosa et Alosa fallax spp.) : Ecobiologie, et variabilité des populations. J.L. BAGLINIÈRE et P. ELIE (Eds), INRA-CEMAGREF, Paris, 33-53.

MENNESSON-BOISNEAU C., BAGLINIĖRE J.L., 1992. Mise au point d'une méthode de détermination de l'âge de la grande Alose (Alosa alosa) à partir des écailles. In : Tissus durs et âge individuel des vertébrés. J.L. BAGLINIĖRE, J. CASTANET, F. CONAND, F.J. MEUNIER (Eds), ORSTOM-INRA, Paris, 221-231.

MENNESSON-BOISNEAU C., BOISNEAU P., 1990. Recherches sur les aloses du bassin de la Loire : Migration, Répartition, Reproduction, Caractéristiques biologiques et Taxonomie des aloses (Alosa sp.). Thèse doctorat, Universités de Rennes et de Paris Val de Marne, $143 \mathrm{p}$.

MENNESSON-BOISNEAU C., BOISNEAU P., BAGLINIĖRE J.L., 1986. Premières observations sur les caractéristiques biologiques des adultes de grande Alose (Alosa alosa L.) dans le cours moyen de la Loire. Acta Oecologica Oecol. Applic., 7, 337-353.

OMBREDANE D., BAGLINIÈRE J.L., 1992. Les écailles et leurs utilisations en écologie halieutique. In: Tissus durs et âge individuel des vertébrés. J.L. BAGLINIĖRE, J. CASTANET, F. CONAND, F.J. MEUNIER (Eds), ORSTOM-INRA, Paris, 151192.

QUIGNARD J.P., KARTAS F., 1977. Les aloses fintes, Alosa fallax (Lacépède, 1803), poissons clupéiformes de l'Atlantique Nord-Est et de la Méditerranée : Etude des caractères numériques. Bull. Muséum Nat. Hist. Natur., $3^{\text {ìme }}$ série, 501, 1241-1256.

RICHARD A., BAGLINIĖRE J.L., 1990. Description et interprétation des écailles de Truite de mer (Salmo trutta L.) des deux rivières de Basse-Normandie : I'Orne et la Touques. Bull. Fr. Pêche Piscic., 319, 239-257.

ROULE L., 1924. Les aloses des eaux douces de France. Bull. Soc. Zool. France, 49, 265266.

SABATIÉ R., 1993. Recherches sur l'Ecologie et la Biologie des aloses au Maroc (Alosa alosa Linné, 1758 et Alosa fallax Lacépède, 1803) : Exploitation et Taxonomie des populations atlantiques, Bioécologie des aloses de l'Oued Sebou. Thèse doctorat, Université de Bretagne Occidentale, Brest, $326 \mathrm{p}$.

SABATIÉ R., ALEXANDRINO P., BAGLINIÈRE J.L., 1996. Comparaison des caractéristiques biologiques des aloses vraies (Alosa alosa) de l'oued Sebou (façade atlantique du Maroc) et du Lima (Portugal). Cybium, 20 (suppl.), 59-73.

TAVERNY C., 1991. Contribution à la connaissance de la dynamique des populations d'Aloses (Alosa alosa et Alosa fallax) dans le système fluvio-estuarien de la Gironde : Pêche, Biologie et Ecologie. Etude particulière de la dévalaison et de l'impact des activités humaines. Thèse doctorat, Université de Bordeaux I, $568 \mathrm{p}$.

TAVERNY C., CASSOU-LEINS J.J., CASSOU-LEINS F., ELIE P., 2000. De l'œuf à l'adulte en mer. In: Les aloses Alosa alosa et Alosa fallax spp.) : Ecobiologie et variabilité des populations. J.L. BAGLINIĖRE et P. ELIE (Eds), INRA-CEMAGREF, Paris, 93-124. 
